\title{
Nudging för hållbar konsumtion av elektronikprodukter
}

Beteende vid köp och användning av elektronik, med en pilotstudie om nudging för hållbar konsumtion av mobiltelefoner bland ungdomar 





\section{Nudging för hållbar konsumtion av elektronikprodukter}

Beteende vid köp och användning av elektronik, med en pilotstudie om nudging för hållbar konsumtion av mobiltelefoner bland ungdomar

Amanda Stefansdotter, Jossi Steen-Knudsen, Martin Flack och Pelle Guldborg Hansen 
Nudging för hållbar konsumtion av elektronikprodukter

Beteende vid köp och användning av elektronik, med en pilotstudie om nudging för hållbar konsumtion av mobiltelefoner bland ungdomar

Amanda Stefansdotter, Jossi Steen-Knudsen, Martin Flack och Pelle Guldborg Hansen

ISBN 978-92-893-4493-7 (PRINT)

ISBN 978-92-893-4494-4 (PDF)

ISBN 978-92-893-4495-1 (EPUB)

http://dx.doi.org/10.6027/TN2016-511

TemaNord 2016:511

ISSN 0908-6692

(c) Nordiska ministerrådet 2016

Layout: Hanne Lebech

Omslagsfoto: ImageSelect

Tryck: Rosendahls-Schultz Grafisk

Printed in Denmark

Denna rapport är utgiven med finansiellt stöd från Nordiska ministerrådet. Innehållet i rapporten avspeglar inte nödvändigtvis Nordiska ministerrådets synpunkter, åsikter eller rekommendationer.

www.norden.org/nordpub

\section{Det nordiska samarbetet}

Det nordiska samarbetet är ett av världens mest omfattande regionala samarbeten. Det omfattar Danmark, Finland, Island, Norge och Sverige samt Färöarna, Grönland och Åland.

Det nordiska samarbetet är politiskt, ekonomiskt och kulturellt förankrat och är en viktig partner i europeiskt och internationellt samarbete. Den nordiska gemenskapen arbetar för ett starkt Norden i ett starkt Europa.

Det nordiska samarbetet ska stärka nordiska och regionala intressen och värderingar i en global omvärld. Gemensamma värderingar länderna emellan bidrar till att stärka Nordens ställning som en av världens mest innovativa och konkurrenskraftiga regioner.

\section{Nordiska ministerrådet}

Ved Stranden 18

DK-1061 København K

Telefon (+45) 33960200

www.norden.org 


\section{Innehåll}

Ordlista

Förord

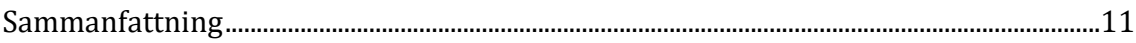

Ökad konsumtion av elektronik ...................................................................................11

Konsumentinriktade insatser för att motverka utvecklingen .....................................11

Nudging för hållbar konsumtion ...............................................................................12

Teoretisk potential för nudging.....................................................................................12

Pilotstudie om nudging för hållbar konsumtion av mobiltelefoner ............................13

Mobilmarknadens struktur hindrar eventuellt användning av nudging..................14

Policyrekommendationer................................................................................................15

1. Introduktion - hållbar konsumtion av elektronik........................................................19

1.1 Konsumtion av elektronikprodukter ökar........................................................19

1.2 Hållbar konsumtion kräver minskade mängder elektronikavfall ..................22

1.3 Allt fler insatser riktas mot konsumenter ...........................................................24

1.4 Beteendeekonomin erbjuder möjlighet till bättre fungerande styrmedel.25

2. Teoretiska och praktiska insikter från beteende ekonomi för en mer hållbar elektronikkonsumtion...

2.1 Traditionella styrmedel för hållbar konsumtion är utformade för rationella konsumenter.

2.2 Varför beter vi oss inte alltid som ekonomerna tror? ......................................33

2.3 Nudging kan användas för att hjälpa konsumenter göra hållbara val för elektronikkonsumtion ............................................................................................. 40

2.4 Nudging snarare ett komplement än en helhetslösning ..................................46

3. Experiment av konsumtion av mobiltelefoner bland unga..........................................49

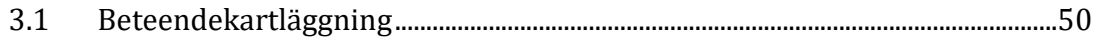

3.2 Sammanfattande slutsatser från beteendekartläggningen................................58

3.3 Två experiment ......................................................................................................59

3.4 Nudging för ökad reparation och köp av begagnade telefoner........................59

3.5 Decoy-effekten för ökad leasing och köp av "gröna" telefoner........................65

4. Slutsatser och policyimplikationer ...............................................................................69

4.1 Övergripande observationer och generella rekommendationer kring nudging för hållbar konsumtion ..........................................................................70

4.2 Observationer och rekommendationer angående nudging och mobiltelefonmarknaden ..........................................................................................74

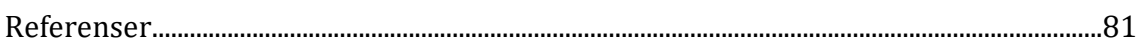

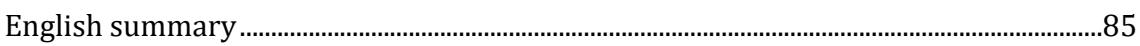

Increased consumption of electronic goods...............................................................8

Consumer-oriented instruments to counteract the development..............................85

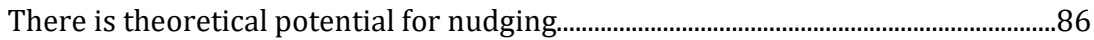

Pilot study of nudging and sustainable consumption of mobile phones ...................87

Market structure might prevent the use of nudging ...................................................8

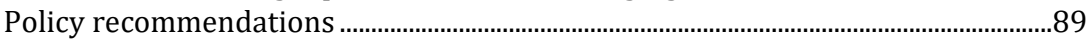


Bilaga A - Beteenden relevanta för hållbar konsumtion av elektronik.

Bilaga B - Intervjuer, praktiska insikter om beteendeekonomi och elektronikkonsumtion

Generella intervjufrågor (anpassat efter intervjuperson)......................................... 97

Bilaga C - Frågeformulär i pilotstudie av nudging för hållbar

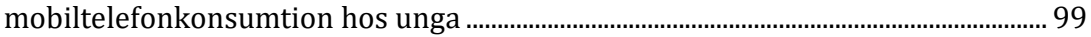

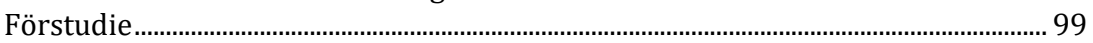

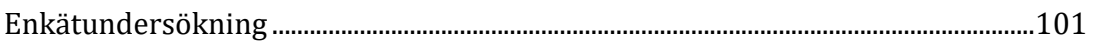

Bilaga D - Resultat i pilotstudie av nudging för hållbar mobil- telefonkonsumtion

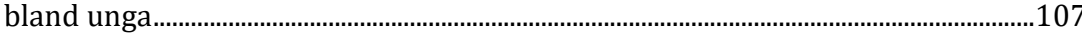

Återvinning/återlämning av mobiltelefoner................................................................109

Bilaga E - Experiment 1, version 1: ny mobil eller skärmreparation....................................113

Bilaga F - Experiment 1, version 2: ny eller begagnad mobil..........................................117

Bilaga G - Experiment 1, version 3: enbart ny mobil (referensscenario).......................121

Bilaga H - Experiment 2, version 1: med och utan hyr-nudge .......................................125

Bilaga I - Experiment 2, version 2: med och utan grön nudge .........................................127 


\section{Ordlista}

- Valarkitektur: Sammanhanget i vilket individer gör val.

- Nudge: En förändring i valarkitekturen som påverkar beslutet hos en individ utan att begränsa dennes valmöjligheter eller avsevärt ändra ekonomiska incitament.

- Beteendeekonomi: Vetenskap som studerar hur individer fattar ekonomiska beslut i praktiken.

- Konsumenters preferenser: Relativ efterfrågan på en vara eller tjänst jämfört med andra varor och tjänster.

- Nyttomaximering: Den mängd och sammansättning av varor och tjänster som maximerar konsumenters nytta givet preferenser och budget. Ett grundantagande är att människan agerar och beter sig på ett sätt som är rationellt, i linje med dennes preferenser och avsikter.

- Decoy: Ett valalternativ som objektivt sett är sämre än andra, vars introduktion ökar sannolikheten att konsumenter väljer ett visst alternativ.

- Psykologisk diskontering: Att lägga mer vikt vid de kortsiktiga konsekvenserna av beslut än de långsiktiga.

- "Fullständig" självkontroll: beslut som tas genom logiska överväganden. 


\section{Förord}

För att ställa om från den linjära ekonomiska modell som dominerar idag till en cirkulär ekonomi med en högre grad av återvinning och återanvändning krävs politiska insatser som främjar mer hållbara affärsmodeller och produktionsprocesser. Elektronikprodukter som datorer, TV-apparater och inte minst mobiltelefoner är en viktig del i detta. Det krävs också insatser på konsumtionssidan för att underlätta hållbara val.

Här kan ny kunskap från beteendeekonomisk forskning bidra till att skapa bättre underlag för politiker och andra beslutsfattare. Nordiska ministerrådet i form av arbetsgrupperna Nordiska avfallsgruppen (NAG) och Hållbar konsumtion och produktion (HKP) har gett Copenhagen Economics i uppdrag att genomföra en pilotstudie av hur dessa kunskaper kan tillämpas för att öka förståelsen för ungdomars konsumtionsmönster när det gäller mobiltelefoner och hur detta beteende kan påverkas i en mer hållbar riktning med hjälp av så kallad nudging - att utan tvång "puffa" konsumenter mot mer hållbara konsumtionsval. Uppdraget har också omfattat att sammanfatta den senaste forskningen på området samt kartlägga hur beteendevetenskapliga insikter används i praktiken idag av myndigheter och andra offentliga aktörer. I denna rapport redovisas de huvudsakliga slutsatserna från detta arbete. Av projektet kan man dra slutsatsen att konsumtionen av mobiltelefoner inom målgruppen unga kan vara ett område där nudging kan vara verkningsfullt, men utökade studier behövs.

Projektet har genomförts av en projektgrupp bestående av konsulter från Copenhagen Economics i både Sverige och Danmark samt i samarbete med Pelle Guldborg Hansen vid Roskilde Universitet. Projektledare har varit Amanda Stefansdotter.

HKP gruppen tackar för ett väl utfört arbete och intressanta slutresultat.

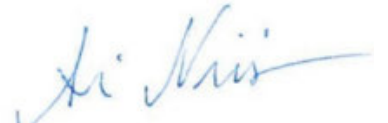

Ari Nissinen,

Ordförande för HKP,

enhetschef för miljöeffektivitet,

Finlands miljöcentral 


\section{Sammanfattning}

\section{Ökad konsumtion av elektronik}

Konsumtion av elektronikprodukter har ökat stadigt i Norden under de senaste två decennierna, vilket skapar en associerad ökning i mängden elektroniskt avfall. Ökad elektronikanvändning medför ett antal miljöproblem, som lokala miljö- och hälsorelaterade problem i samband med utvinning av material som används i elektronik samt i samband med hanteringen av elektroniskt avfall, liksom ökad elförbrukning. Det främsta styrmedlet för att motverka trenden med ökad konsumtion av elektronik är producentansvaret, vilket innebär att de som säljer elektronik också har ansvar för det avfall som uppstår av försäljningen. En teoretisk fördel med systemet är att producenter - genom att ha ansvar för produktens slutmål - uppmuntras att minimera insamlingsoch återvinningskostnaderna redan vid produktionen. Systemet har dock vissa praktiska tillkortakommanden, till exempel att den kollektiva insamlingen av elektronik gör att enskilda företags insatser för att minimera materialanvändningen ger liten effekt på totalen; vinsterna tillfaller alla i systemet och kommer inte det investerande företaget till godo.

\section{Konsumentinriktade insatser för att motverka utvecklingen}

Det finns en växande medvetenhet om att politiska åtgärder riktade mot utbudssidan (produktion) behöver kompletteras med åtgärder riktade mot efterfrågesidan (konsumtion) för att få individer att välja mer hållbara val. Det innefattar insatser som făr konsumenter att köpa färre elektronikprodukter, köpa mer miljövänliga eller långlivade elektronikprodukter, använda produkter de äger längre, återanvända elektronikprodukter i större utsträckning och återvinna uttjänta produkter.

De flesta politiska verktyg för ett mer hållbart konsumtionsbeteende idag utgår från en syn på konsumenter som ekonomiskt rationella. Dessa antaganden har delvis visat sig otillräckliga när det gäller att förutspå och 
påverka beteenden, då konsumenter ofta avviker från det beteende som förutspås av klassiska ekonomiska modeller. Beteendeekonomin försöker kartlägga och förstå dessa avvikelser, och på så vis på ett mer rättvisande sätt förutspå hur konsumenter beter sig. I ökande grad används den här kunskapen också för att utforma politiska styrmedel. Insikterna från beteendeekonomin underlättar för beslutsfattare att förstå mänskligt beteende och de faktorer som påverkar beteendeförändring, men också för att ta fram strategier för att främja hållbara konsumtionsmönster.

\section{Nudging för hållbar konsumtion}

Vi fokuserar i den här rapporten på möjligheten att använda nudging för att öka hållbar konsumtion av elektronik: att utan tvång "puffa" konsumenter mot mer hållbara konsumtionsval. En nudge kan definieras som sättet att utforma en valsituation och sättet att presentera olika alternativ (även kallat valarkitekturen), för att förändra människors beteende på ett förutsägbart sätt utan att eliminera deras möjligheter eller ändra underliggande incitament genom att till exempel ändra priserna. Målet med att introducera en nudge är att hjälpa individer att fatta de beslut som de själva skulle gjort om de varit uppmärksamma, haft fullständig information och fullständig självkontroll. Skälen till att de inte gör det från början kan vara en varierande uppsättning: det är ansträngande att göra saker, lätt att skjuta på dem och lätt att glömma även om vi vet att vi borde. Många beslut är i grunden komplexa med ett stort antal val, osäkert utfall och många olika önskemål som ska balanseras. Andra är rutinmässiga och vi tänker inte över vad vi gör. Vi påverkas av vad våra vänner tycker och gör, vad vi tror är accepterat $\mathrm{i}$ samhället, vad vi tror väntas av oss etc. Det är på det hela taget många olika faktorer som spelar in när människor bestämmer sig för att agera eller inte agera hållbart i olika situationer. Vi kartlägger i rapporten vilka de viktigaste faktorerna som spelar in vid beslut om konsumtion av elektronik, och hur nudging har använts och kan användas för att öka hållbar konsumtion av elektronik.

\section{Teoretisk potential för nudging}

Resultaten visar att det finns en teoretisk potential att använda nudging för att främja hållbar konsumtion av elektronik, främst vid köp av ny elektronik men också för att få individer att använda produkter längre 
(genom att exempelvis öka reparationer) och vid beslut om återvinning. Det har i vår kännedom inte gjorts några studier om nudging och elektronikkonsumtion, men vi kartlägger olika beteenden och nudges från kringliggande områden som kan tänkas vara relevanta också för elektronikkonsumtion. Detta görs översiktlig eftersom beteenden skiljer sig signifikant åt mellan olika typer av köp inom elektronik (småel, vitvaror etc.), olika situationer vad gäller konsumtion av elektronik (köp, beslut om återanvändning, återvinning) och olika demografiska grupper (unga gentemot äldre etc.). Den forskningslitteratur som finns på området är mycket tydlig med att nudging främst är effektivt för att främja beteendeförändringar i specifika sammanhang, och att resultat från en situation inte godtyckligt kan generaliseras till ett annat sammanhang eller till en bredare population.

\section{Pilotstudie om nudging för hållbar konsumtion av mobiltelefoner}

I en pilotstudie går vi därför djupare in på en specifik kategori av konsumentbeteenden för elektronik: konsumtion av mobiltelefoner i åldersgruppen 19 till 28 år. I pilotstudien gör vi först en beteendekartläggning över ungas konsumtion av mobiltelefoner i syfte att identifiera om det finns oavsiktliga beteenden eller beteendehinder som hämmar hållbar konsumtion. Ett antal observationer talar för att så är fallet, och att det därmed kan finnas utrymme för nudging. Till exempel noterar vi att relativt många ungdomar väljer att köpa en ny telefon när den gamla är trasig, utan att först undersöka om den istället skulle gå att reparera. Vi noterar också att unga när de köper en ny telefon ofta rutinmässigt går till den butik där de köpte sin gamla. En ytterligare intressant observation är att unga uppvisar en viss miljömedvetenhet och betalningsvilja för "gröna" telefoner samt leasing-tjänster.

Vi genomförde två kontrollerade experiment som testar effekten av olika nudges på ungas konsumtionsbeslut. I det första experimentet undersöker vi hur nudging kan påverka beslutet att köpa en ny mobiltelefon när den gamla är trasig. Nudgen som undersöks är aktiv marknadsföring av två alternativa möjligheter: att reparera den gamla mobiltelefonen eller att köpa en begagnad telefon. I det andra experimentet undersöker vi hur nudging kan öka leasing och köp av "gröna" mobiltelefoner. Detta görs genom att introducera en så kallad decoy (ungefär ett lockbete på svenska). Utgångspunkten för decoyeffekten är att det kan vara svårt att välja mellan två alternativ där inget 
objektivt sett är bättre än det andra. Valet blir lättare om det införs ett tredje alternativ som objektivt sett är sämre än ett av de två första. Man kan exempelvis introducera en telefon som kan hyras, men till villkor som är mindre förmånliga än för en annan hyrtelefon. Då ökar sannolikheten för att konsumenterna väljer hyrtelefonen med bättre villkor eftersom de nudgas mot detta alternativ.

Experimenten visar att ungdomar verkar ha en preferens för att agera hållbart - många vill till exempel reparera mobilen när den går sönder men kan eller gör inte alltid detta. Att framhålla dessa alternativ vid köptillfället kan spela en roll i att hjälpa dem agera enligt sina preferenser. Experimenten visar också att leasing verkar vara ett alternativ som tilltalar somliga. Den nudge vi testade för att öka valet av "gröna" mobiler jämfört med konventionella alternativ visade sig dock verkningslös i experimentet.

Tabell: Resultat av experiment i pilotstudie

\begin{tabular}{lll} 
Nudge & Beskrivning & Effekt \\
$\begin{array}{l}\text { Experiment 1 } \\
\begin{array}{l}\text { Nudging för ökade } \\
\text { reparationer }\end{array}\end{array}$ & $\begin{array}{l}\text { Alternativet "reparation" framhålls i } \\
\text { samband med erbjudande om en ny } \\
\text { telefon, i en simulerad köpsituation }\end{array}$ & Nudge ger statistiskt signifikant skillnad \\
$\begin{array}{l}\text { Nudging för } \\
\text { begagnade } \\
\text { telefoner }\end{array}$ & $\begin{array}{l}\text { Alternativet "begagnad telefon" framhålls i } \\
\text { samband med erbjudande om en ny } \\
\text { telefon, i en simulerad köpsituation }\end{array}$ & Nudge ger statistiskt signifikant skillnad \\
$\begin{array}{l}\text { Experiment 2 } \\
\text { Nudging för ökad } \\
\text { leasing }\end{array}$ & $\begin{array}{l}\text { En decoy (ett icke-relevant alternativ) läggs } \\
\text { till i en simulerad köpsituation }\end{array}$ & Nudge ger statistiskt signifikant skillnad \\
$\begin{array}{l}\text { Nudging för "gröna } \\
\text { telefoner" }\end{array}$ & $\begin{array}{l}\text { En decoy (ett icke-relevant alternativ) läggs } \\
\text { till i en simulerad köpsituation }\end{array}$ & Nudge ger inte statistiskt signifikant skillnad \\
\hline
\end{tabular}

Källa: Copenhagen Economics.

\section{Mobilmarknadens struktur hindrar eventuellt användning av nudging}

Det finns en inbyggd problematik i att överföra ovanstående observationer till verkligheten: marknaden för mobiltelefoner har idag inte den typ av aktörer som skulle krävas för att implementera resultaten. Återförsäljare av mobiltelefoner erbjuder idag generellt inte reparation, och i begränsad utsträckning begagnade telefoner. Det ligger därmed inte i deras intresse att framhålla dessa alternativ utan att bredda sitt erbjudande. Att påminna om möjligheter utanför företagets verksamhet 
skulle leda till minskad försäljning i butiken, vilket gör att återförsäljare inte har incitament att göra detta. Producenter av mobiltelefoner drivs också av företagsekonomiska motiv att sälja stora kvantiteter och på så sätt att göra vinst, och har därmed heller inte incitament att i dagens läge framhålla andra alternativ. Dessutom finns en rad andra hinder för hållbar konsumtion av mobiltelefoner som har med marknadens struktur att göra, exempelvis de abonnemang som operatörer erbjuder, planerad utfasning där mobiltelefoner blir obrukbara efter ett visst antal uppdateringar av mjukvara. Snabb teknikutveckling gör också telefoner utdaterade innan dess faktiska livslängd är över.

Den här studien utgår från konsumenternas perspektiv. För att fullt kunna använda resultaten behövs, i tillägg till ytterligare studier på detta område, en analys som utgår från producenter och återförsäljare på mobiltelefonmarknaden. För att applicera insikter om nudging för mobiltelefoner behöver vi veta i vilka fall de företagsekonomiska motiven är jämkade med de samhällsekonomiska, och i vilka fall dessa står i motsatsförhållande till varandra. I det föregående fallet kan fungerande nudging i butiker eventuellt behöva understödjas av reglering av exempelvis vilken information affärer behöver visa vad gäller reparationskostnader, begagnade telefoner och "gröna" alternativ. I det sistnämnda fallet är insatser antagligen mindre komplicerade. Exempelvis kan återförsäljare av begagnade telefoner samt ställen som reparerar mobiltelefonen antas ha incitament att nudga konsumenter mot dessa alternativ, exempelvis med hjälp av jämförelsepriser mellan nya och begagnade telefoner. Dessa marknader är dock relativt outvecklade idag, och behöver fungera väl för att konsumenter ska välja dessa alternativ, och tjäna på valen.

\section{Policyrekommendationer}

Figuren nedan sammanfattar de huvudsakliga policyimplikationerna vi drar av studiens resultat. Implikationerna är segmenterade på olika nivåer, baserat på vilken typ av aktörer de riktar sig mot. På den första nivån finns regeringar i de nordiska länderna, som sätter miljöpolitiken. På den andra nivån finns genomförare, och på den tredje finns utvärderare. Som kunskapsspridare och hjälp finns nordiska organisationer som Nordiska ministerrådet. De olika rekommendationerna beskrivs mer utförligt nedan. 
Figur: Nordiska ministerråd och nordiska organisationer

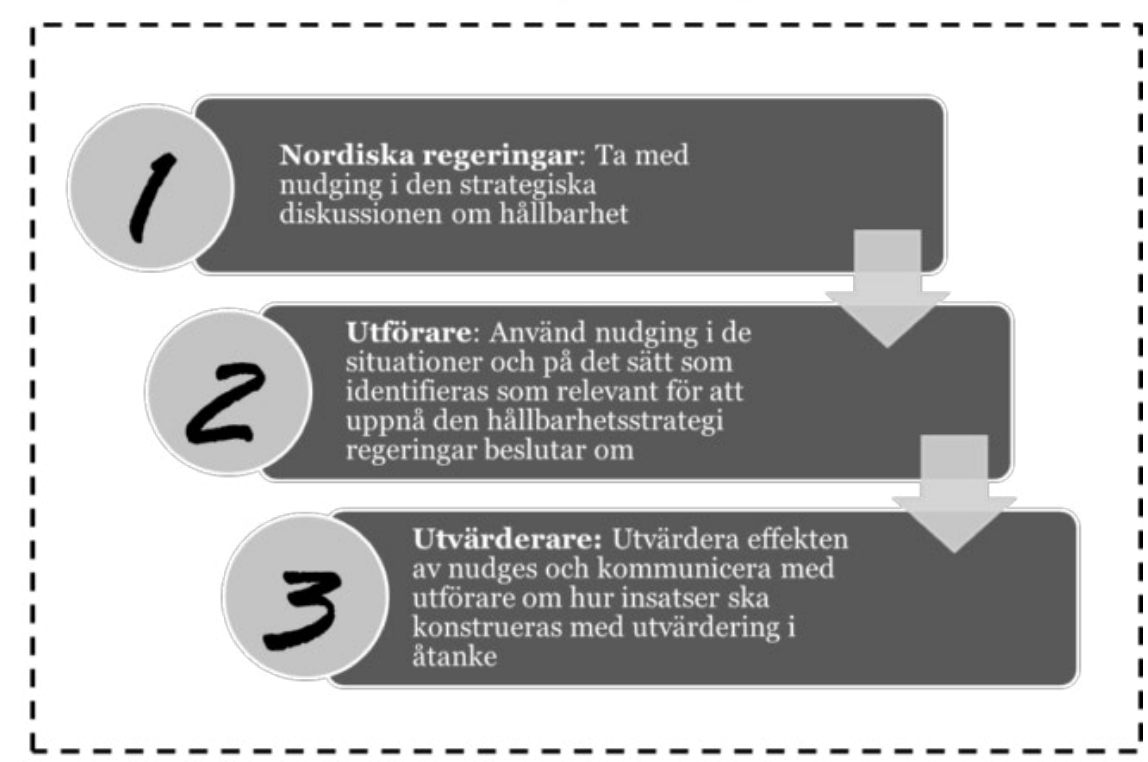

1. Regeringar: Den strategiska diskussionen om hållbarhetspolitik bör inkludera nudging som ett potentiellt verktyg. Strategier för att öka hållbar konsumtion bör gå ut på att lösa de identifierade problemen, och definiera hur. Strategin bör alltså inte vara låst till ett eller vissa verktyg utan syftet måste vara att problemen ska lösas med hjälp av de mest lämpliga verktygen. Nudging kan vara en självständig del detta, men kan också vara en del i ett övergripande styrmedelspaket, exempelvis som komplement till andra styrmedel eller för att förstärka effekten av dessa.

2. Utförare: Utförande aktörer som kommuner eller operativa myndigheter bör arbeta med nudging i den utsträckning det passar in i deras övergripande uppdrag. Vi har intervjuat representanter främst på kommunnivå i Sverige, och de säger sig vara intresserade av att använda insikter från beteendeekonomin men att de saknar kunskap om hur man kan och bör gå tillväga. En allmän vägledning till nudging för miljöarbete skulle kunna bidra till ökad kunskap och samsyn kring nyttan och utmaningarna med nudging. Den bör innehålla tydliga steg - beteendekartläggning, analys och problemidentifiering, lösning/nudgingdesign, utvärdering och lärande - med praktiska exempel som kan hjälpa organisationer som vill arbeta med nudging att göra detta på ett strukturerat sätt. 
3. Utvärderare: Det kan inte nog understrykas att kunskapen om vilka effekter nudging kan ha är outvecklad och att insamling av uppgifter som möjliggör utvärdering och lärande bör vara en central del av varje nudgingprojekt. Nudges bör konstrueras med utvärdering i åtanke, och utvärderande myndigheter i de nordiska länderna bör ges i uppdrag att utvärdera effektiviteten i insatserna. För att göra detta behöver utvärderare kunskap om nudging. Återkoppling och lärande behöver också ske mellan utförare och utvärderare. 


\section{Introduktion - hållbar konsumtion av elektronik}

\section{Kapitlets innehåll}

Det här kapitlet beskriver inledningsvis hur konsumtion av elektronik i de nordiska länderna har ökat under de senaste decennierna, och vilka drivkrafter som ligger bakom utvecklingen. Kapitlet beskriver vidare övergripligt vilka styrmedel som traditionellt använts för att minska konsumtion av elektronik och därmed associerat avfall, och hur insatser mot producenter allt oftare kompletteras med insatser mot konsumenter. Vi introducerar sist begreppet beteendeekonomi, och hur detta kan hjälpa till att skapa mer effektiva, konsumentinriktade styrmedel för hållbar elektronikkonsumtion.

\subsection{Konsumtion av elektronikprodukter ökar}

Konsumtionen av elektronikprodukter i Norden har fyrdubblats under de senaste två decennierna. ${ }^{1}$ Utvecklingen har stagnerat något sedan mitten på 2000-talet, men faktum kvarstår att omsättningen av varor har ökat dramatiskt under en relativt kort tid. Trenden illustreras för Danmark i Figur 1. Där har exempelvis andelen hushåll som äger mobiltelefoner, datorer och mikrovågsugnar ökat stadigt under de senaste 15 åren.

\footnotetext{
${ }^{1}$ Begreppet elektronikprodukter innefattar produkter som ger upphov till elavfall enligt direktiv 2012/19/EU. Denna typ av avfall kallas även WEEE (Waste Electrical and Electronic Equipment), och definieras som "avfall som utgörs av eller innehåller elektrisk och elektronisk utrustning". Specifika produktkategorier inom direktivet är stora hushållsapparater, små hushållsapparater, it- och telekommunikationsutrustning, hemutrustning och solcellspaneler, belysningsutrustning, elektriska och elektroniska verktyg (med undantag för storskaliga, fasta industriverktyg), leksaker samt fritids- och sportutrustning, medicintekniska produkter (med undantag för alla infekterade produkter och implantat), övervaknings- och kontrollinstrument, automater.
} 
Figur 1: Andel hushåll i Danmark med olika typer av hemelektronik

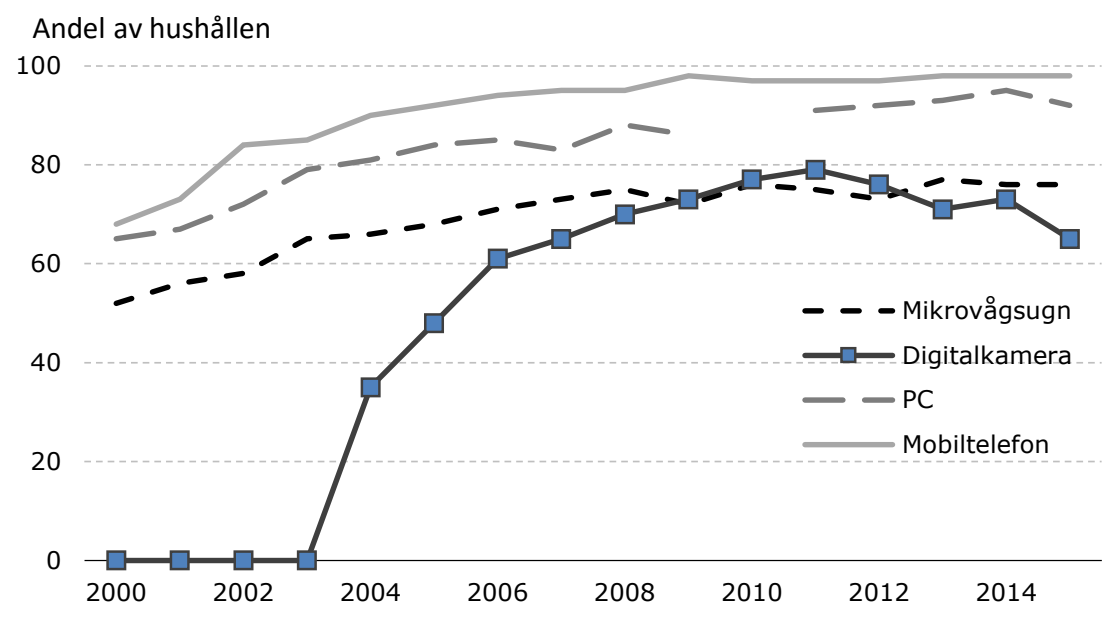

Källa: Copenhagen Economics baserat på statistikbanken.dk

Ett område som sticker ut särskilt är mobiltelefoner. Statistik från MobilTeleBranchen visar till exempel att nästan 4 miljoner mobiltelefoner såldes i Sverige under 2013; det är en nästan sjuttonfaldig ökning på 20 år, se Figur 2. Samtidigt har andelen av befolkningen som äger en surfplatta ökat från 5 \% 2011 till över 50 \% 2014 (Mobilbusiness, 2014).

Figur 2: Totalt antal sålda mobiltelefoner i Sverige 1993 till 2014

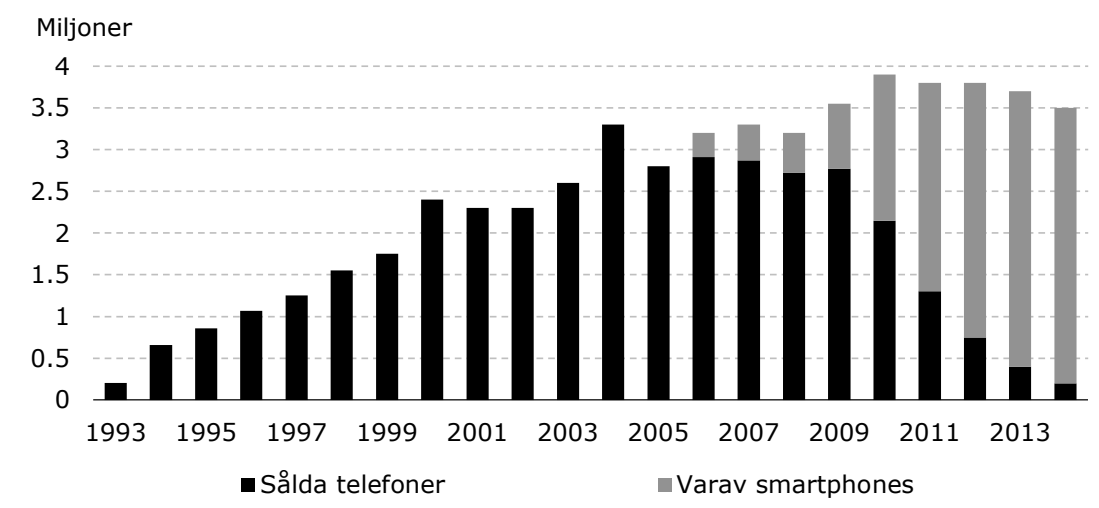

Källa: Copenhagen Economics baserat på MTB (MobilTeleBranschen). 
Den ökade konsumtionen av elektronikprodukter och associerat avfall drivs därmed i grunden av en snabb teknisk innovationstakt. Kontinuerlig produktutveckling gör exempelvis att befintliga informations- och kommunikationsprodukter blir föråldrade långt innan den faktiska teknik är uttjänt, och det förklarar varför konsumenter ofta byter ut dessa produkter. ${ }^{2}$ Detta skapar i sin tur incitament för företag att bygga affärsmodeller som är baserade på ett linjärt resursflöde, vilket driver på investeringar i ytterligare produktutveckling. Fallande priser på komponenter, effektivare produktionsprocesser och ökad outsourcing till lågkostnadsländer har också lett till att elektronikprodukter blir allt billigare för konsumenter, vilket driver utvecklingen ytterligare. Detta har skett samtidigt som köpkraften hos befolkningen i Norden stigit, vilket gett allt större konsumtionsutrymme.

En annan förklaring till den höga omsättningstakten är att livslängden på många produkter faktiskt har minskat. Luttropp et al. (2013) beskriver hur dammsugare på 1960-talet höll i 15 till 20 år innan de behövde bytas ut, medan dagens billiga varianter bara kanske håller i 1 år. En förklaring är att längre livslängd leder till minskad försäljning för producenter, eftersom produkterna då inte behöver bytas ut lika ofta. Detta skapar incitament att förkorta levnadstiden och förstärker den negativa spiral som beskrivs ovan (Löf, 2013).

Efterfrågan på elektronikprodukter har också ökat som ett resultat av att produkterna över tid både blivit fler och bättre. De tillfredsställer uppenbarligen behov som många människor har och underlättar tillvaron på allt fler områden. Datorer och mobiltelefoner blir integrerade i allt fler vardagsaktiviteter och är avgörande för interaktion mellan människor. I takt med teknikutvecklingen har vi vant oss vid att ha en viss uppsättning funktioner omkring oss, såsom kylskåp, kaffebryggare, hårtork, smartphone, tv och dator, samtidigt som flera produkter i hemmet har samma funktionalitet. Var och en i familjen kan alltså ha en egen dator, smartphone, hårtork etc.

Dessutom har framgångsrik marknadsföring och starka varumärken gjort att i synnerhet mobiltelefoner ses som statussymboler och är en del av många individers identitet. I detta ingår exempelvis att tidigt köpa nya modeller av mobiltelefoner - köerna utanför Apples butiker i samband med lansering av en ny produkt är ett illustrativt exempel på detta.

Tillväxten i konsumtion av elektronikprodukter drivs därmed av en kombination av två saker: Den första är tekniska förändringar i form av snabb produktutveckling, i kombination med masstillverkning och 
möjlighet för företag att minimera kostnader i globala värdekedjor. Den andra är förändringar i sociala relationer och utveckling i ekonomiska förutsättningar, i kombination med ökad specialisering.

\subsection{Hållbar konsumtion kräver minskade mängder elektronikavfall}

De ökade konsumtionsvolymerna medför ett värde för individen såväl som för samhället eftersom fler funktioner och användningsområden för teknik underlättar i vardagen och ökar den sociala interaktionen mellan människor. En oönskad bieffekt är dock allt större volymer av elavfall, vilket för med sig ett antal miljöproblem. Exempelvis uppstår lokala miljöoch hälsorelaterade problem i samband med utvinning av material som används i elektronik samt i samband med hanteringen av elektroniskt avfall. Många elektronikprodukter innehåller skadliga ämnen såsom kvicksilver och bromerade flamskyddsmedel som är svåra att isolera och återvinna (Christensen et al. 2007).

Med fler elektriska apparater i hushållen ökar också elförbrukningen. Elektroniska apparater i standby-läge har exempelvis visat sig stå för runt $9 \%$ av elanvändningen i norska bostäder, se Figur 3.

Figur 3: Fördelning av elektricitetsanvändning i norska hushåll

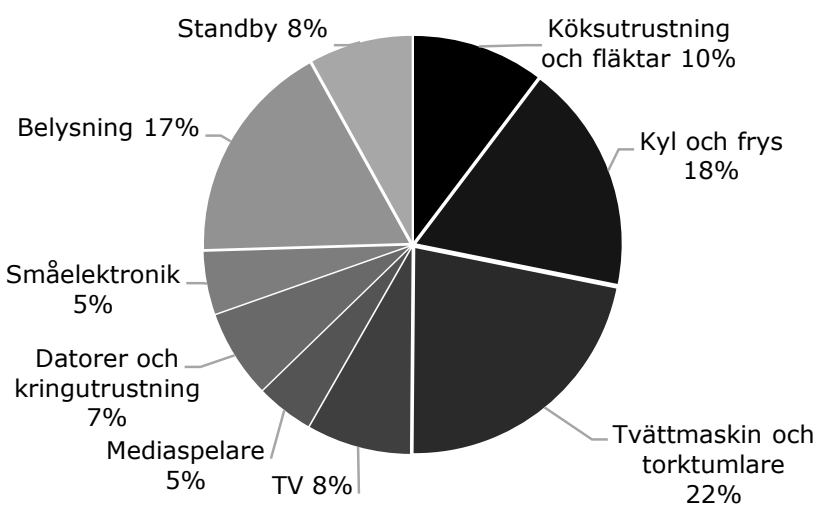

Källa: Xrgia (2011).

Hållbar konsumtion av elektronik är en fråga som klättrar på den globala politiska agendan. För elektronikkonsumtion förespråkas en "ekologisk" hållbar konsumtion, bland annat som utgångspunkt för den huvudsakliga EU-lagstiftningen för hantering av elektronikavfall: Waste Electrical and Electronic Equipment (WEEE)-direktivet. Ekologisk hållbar konsumtion innebär att befintliga varor och tjänster görs mer hållbara, och att 
konsumenter uppmuntras att välja dessa varor. ${ }^{3}$ Den främsta åtgärden är att förebygga uppkomsten av elavfall, och därefter ska konsumtionen bli hållbar genom återanvändning och slutligen genom återvinning. Målet är att minimera elavfallets påverkan på miljön samt att hantera detta på ett hållbart och miljömässigt korrekt sätt. I en optimal situation återbördas allt avfall till produktionen, för att skapa ett cirkulärt flöde i elektronikproduktion. Figur 4 illustrerar skillnaden mellan en linjär produktionskedja, till en cirkulär motsvarighet.

Figur 4: Från linjär till cirkulär elektronikkonsumtion

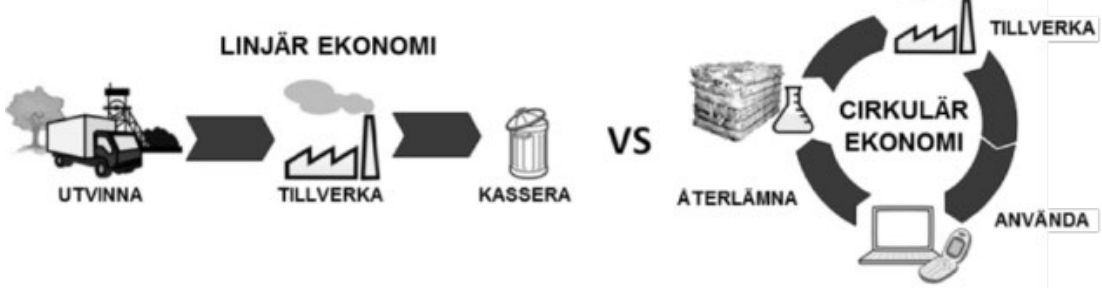

Källa: Copenhagen Economics.

Det främsta styrmedlet för att uppnå målsättningarna inom WEEEdirektivet är producentansvar. Det innebär att de som säljer elektronik också har ansvar för det avfall som uppstår av försäljningen. En teoretisk fördel med systemet är att producenter - genom att ha ansvar för produktens slutmål - uppmuntras att minimera insamlings- och återvinningskostnaderna redan vid produktionen. Det finns två ekonomiska motiv för företagen att göra detta: 1) minska storleken och materialmängden i produkterna i syfte att uppnå kostnadsbesparingar, och 2) minska insamlings- och återvinningskostnaderna genom ekodesign. ${ }^{4}$ Eftersom kostnaderna för insamling hamnar på konsumenterna får producenter incitament att minimera kostnaderna för att kunna erbjuda sina kunder konkurrenskraftiga priser.

\footnotetext{
3 Perspektivet hamnar nära begreppet "svag hållbar konsumtion", vilket skiljer sig från "stark hållbar konsumtion". Företrädare för stark hållbar konsumtion framhåller att det är nödvändigt att problematisera konsumtionen i sig, och att minska den totala konsumtionsnivån. Detta kan bara åstadkommas genom att samhället förändras på ett genomgripande plan med förändrade livsstilar och nya eller ombildade infrastrukturer och institutioner för att tillfredsställa våra behov. Förespråkare för svag hållbar konsumtion menar i stället att hållbar konsumtion kan uppnås genom befintliga eller något modifierade sociala, politiska och ekonomiska institutioner utan att avstå från ekonomisk tillväxt. I stället ska renare, effektivare och mindre resurskrävande teknologier göra konsumtionen hållbar. Källa: Löf (2013).

${ }^{4}$ Ekodesign innebär att förbättra produkternas miljöprestanda under hela livscykeln. Detta innefattar bland annat att utforma produkter för att minimera avfall.
} 
Teoretiskt sett är producentansvar en lösning som kan förena de företagsekonomiska motiven med de samhällsekonomiska. ${ }^{5}$ Systemet har dock vissa praktiska tillkortakommanden, som uppstår till exempel av att insamling och återvinning av elektronik sker kollektivt. Detta gör för det första att enskilda företags insatser för att minimera materialanvändningen ger liten effekt på totalen; vinsterna tillfaller alla i systemet och kommer inte det investerande företaget till godo. För det andra uppkommer problem med free-riding när det gäller produkter från producenter som inte är med i det kollektiva insamlingssystemet för elavfall. Dessa producenter drar ändå nytta av systemet eftersom det $\mathrm{i}$ slutändan är svårt att göra skillnad på dessa produkter.

Resultaten visar också att dagens insamlingssystem för elektronik är otillräckliga. I Sverige finns exempelvis undersökningar av hushållsavfallets sammansättning som visar att innehållet av elavfall i stort sett inte har ändrats sedan 2007, trots exempelvis ökad tillgänglighet av insamlingsplatser (Öhrlund, 2012). I en rapport av United Nations University framkommer att Sverige, Norge, Danmark och Island är bland de länder toppar listan över de länder som hade mest elavfall per capita under 2014 (Baldé et al. 2014). Elektriskt och elektroniskt avfall är också den enskilt snabbast växande avfallsströmmen inom EU (Öhrlund, 2012). Instrument som förhindrar utvecklingen måste därmed bli effektivare om hållbarhetsmålen ska nås.

\subsection{Allt fler insatser riktas mot konsumenter}

Det finns en växande medvetenhet om att politiska åtgärder riktade mot utbudssidan (produktion) behöver kompletteras med åtgärder riktade mot efterfrågesidan (konsumtion) på ett sätt som hjälper individer att fatta bättre beslut för sig själva och för samhället i stort. Det finns gott om exempel på konsumtionsinriktade initiativ i de nordiska länderna som, främst genom information, försöker få konsumenter att agera mer miljömässigt hållbart när det gäller elektronik. I en landsomfattande kampanj på tv uppmanades till exempel danska konsumenter att stänga av sina elektriska apparater i stället för att lämna dem på standby. ${ }^{6}$ En annan kampanj uppmuntrade människor att ersätta sina gamla datorskärmar

${ }^{5}$ De samhällsekonomiska motiven är i det här fallet att internalisera de externaliteter som uppstår vid konsumtion. Externaliteter innebär att den som ger upphov till en kostnad eller skada inte bär den fulla effekten av skadan. En person som skräpar ner skapar till exempel en kostnad för andra som måste stå ut med en nedskräpad miljö. Personer som skräpar ner betalar därmed inte full miljökostnad för sitt beteende. ${ }^{6}$ Se till exempel https://www.youtube.com/watch?v=ZsqH-leGYbI 
med platta bildskärmar som förbrukar mindre energi (Christensen et al., 2007). Ytterligare exempel på konsumentorienterade styrmedel är EU:s energimärkningssystem, informationskampanjer från nordiska länders konsumentombudsmän och energi- och miljörådgivning från kommuner. Det är också vanligt med kampanjer i tv och tidningar om vikten av källsortering.

Det ligger ofta i individers eget intresse att minska konsumtionen av elektronik eller välja mer miljövänliga alternativ. Mer långlivade produkter kan vara kostnadseffektiva för konsumenter, och efterfrågan på gröna och hållbara produkter växer allt mer (om än i långsam takt). Frågan är hur vi kan öka takten i utvecklingen och få individer att göra mer hållbara val, det vill säga få konsumenter att köpa färre elektronikprodukter, köpa mer miljövänliga och långlivade elektronikprodukter, använda produkter man äger längre (exempelvis genom att reparera), återanvända elektronikprodukter i större utsträckning och återvinna uttjänta produkter.

\subsection{Beteendeekonomin erbjuder möjlighet till bättre fungerande styrmedel}

Insikter från beteendeekonomin kan ge värdefulla bidrag när det gäller att stödja utvecklingen av en hållbar elektronikkonsumtion. Utgångspunkten för beteendeekonomi är att människor inte kan beskrivas med de enkla antaganden om rationalitet som används i traditionella (neoklassiska) ekonomiska teorier om beslutsfattande. ${ }^{7}$ Empiriska studier av människors faktiska beteende visar att de inte alltid gör de ekonomiskt mest fördelaktiga eller rationella valen, utan i stället är präglade av mentala genvägar, impulser och vanebeteenden. Genom att kartlägga och förstå dessa beteenden kan vi utforma styrmedel som bättre stämmer överens med hur människor fattar beslut. Vi fokuserar i den här rapporten på så kallad nudging för hållbar konsumtion - att utan tvång "puffa" (eller nudga) konsumenter i en hållbar riktning. Nudging tar sin utgångspunkt i att individer påverkas att hur olika valsituationer utformas (även kallat valarkitekturen). En nudge är en aspekt av valarkitekturen som förändrar människors beteende på ett förutsägbart sätt utan att förbjuda alternativ

\footnotetext{
${ }^{7}$ Den neoklassiska skolan kontextualiserar ekonomin till att bestå av vinstmaximerande organisationer och nyttomaximerande konsumenter. Dessa möts på konkurrensutsatta marknader där konsumenter köper den mängd och sammansättning av varor och tjänster som maximerar deras nytta givet en budget, och där företag strävar efter att maximera sin vinst i produktion av de varor och tjänster som konsumenter efterfrågar. Ett grundantagande i teorin är att människan agerar och beter sig på ett sätt som är rationellt, $\mathrm{i}$ linje med dennes preferenser och avsikter.
} 
eller avsevärt ändra deras ekonomiska incitament. För att räknas som en ren nudge måste insatsen vara enkel och billigt att undvika.

I den här rapporten undersöker vi möjligheten att använda nudging och beteendeekonomi för att få konsumenter att köpa färre elektronikprodukter, köpa mer miljövänliga och långlivade elektronikprodukter, återanvända elektronikprodukter i större utsträckning och återvinna sina uttjänta produkter. Vi fokuserar på konsumtion av elektronik, och alltså inte $\mathrm{i}$ första hand på energikonsumtion.

Kapitel 2 går igenom teoretiska och praktiska insikter från beteendeekonomi och fakta om elektronikkonsumtion, och sammanfattar delar av den forskning som finns på området. Vi känner inte till några vetenskapliga experiment på elektronikkonsumtion med specifikt fokus på beteendeekonomi, och därför utgår vi från generella insikter inom beteendeekonomi och konsumenters beteende vid konsumtion av elektronik, och beskriver översiktligt vad som går att applicera i det här fallet. Vi inkluderar också resultaten av en intervjustudie med personer som praktiskt arbetar med konsumenters beteenden vid köp, återanvändning och återvinning av elektronik i de nordiska länderna, och som visar hur de ser på möjligheterna att använda insikter från beteendeekonomi för att påverka konsumtionen i en mer hållbar riktning.

Kapitel 3 innehåller resultaten från en pilotstudie där vi undersöker hur nudging kan påverka mobiltelefonkonsumtion bland unga. Pilotstudien kartlägger de beteenden som orsakar ohållbar konsumtion i denna grupp, föreslår nudges som syftar till att förändra det ohållbara beteendet hos individer utan att ändra eller begränsa deras alternativ eller incitament, samt testar föreslagna nudges i kontrollerade, randomiserade experiment. Figur 5 illustrerar de val och valsituationer som eventuell går att påverka när det gäller en mobiltelefon. 
Figur 5: Illustration av konsumenters val vid elektronikkonsumtion

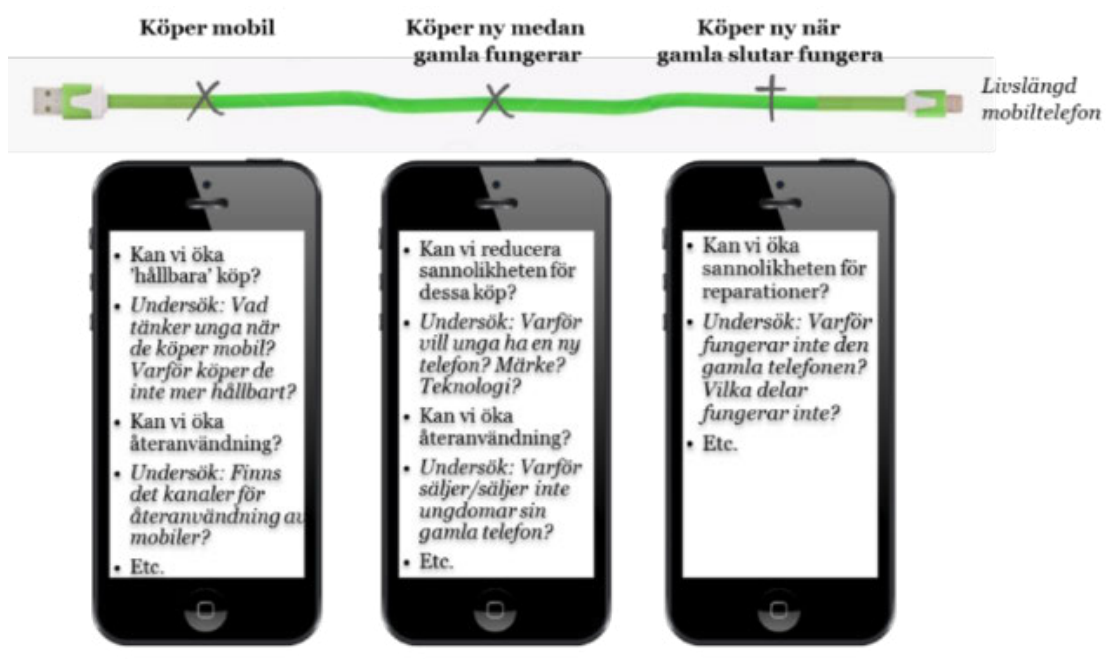

Källa: Copenhagen Economics.

Kapitel 4 sammanfattar och diskuterar resultaten i tidigare kapitel, och föreslår hur resultaten kan användas i de nordiska ländernas politik för hållbar konsumtion. 
2. Teoretiska och praktiska insikter från beteende ekonomi för en mer hållbar elektronikkonsumtion

\section{Kapitlets innehåll}

Det här kapitlet beskriver inledningsvis hur traditionella styrmedel för hållbar konsumtion utgår från att konsumenter fattar ekonomiskt rationella beslut. Till exempel bygger de på antaganden om att konsumenter väljer att maximera den egna (objektiva) välfärden, givet den informationen man har.

I verkligheten uppstår olika beteendehinder som gör att människor ibland avviker från ett ekonomiskt rationellt beteende. Inom beteendeekonomi försöker man kartlägga och förstå dessa avvikelser och på så vis kunna förutspå hur konsumenter beter sig. Vi går i det här kapitlet igenom ett urval avvikelser som vi anser är relevanta för hållbar elektronikkonsumtion.

Vi presenterar konceptet nudging som en möjlighet för beslutsfattare att påverka konsumenters beteenden i en hållbar riktning. En nudge beskrivs här som en medveten förändring av den valsituation som en konsument står inför, som syftar till att påverka konsumentens beteende på ett förutsägbart sätt. Vi ger en rad exempel på hur nudging används i praktiken, återigen med ett särskilt fokus på elektronikkonsumtion, och diskuterar de etiska dimensionerna av nudging. Slutligen diskuterar vi hur nudging förhåller sig till andra styrmedel.

\subsection{Traditionella styrmedel för hållbar konsumtion är utformade för rationella konsumenter}

De flesta politiska verktyg för ett mer hållbart konsumtionsbeteende idag utgår från en syn på konsumenter som ekonomiskt rationella. Enligt denna syn agerar konsumenter på ett sätt som skapar största möjliga nytta för dem själva, genom att bearbeta all tillgänglig information (exempelvis om produkters ursprung och kostnad). Ohållbar konsumtion 
uppkommer när konsumenten exempelvis inte är medveten om miljöeffekterna av sitt handlade, eller inte betalar för alla kostnader som denne själv ger upphov till genom sin konsumtion. ${ }^{8}$ Lösningen i dessa två fall kan, enligt ett traditionellt perspektiv, vara att tillhandahålla mer information eller inkludera kostnader för miljöskador i priset på varor genom en skatt. Sådana lösningar förlitar sig på människors kognitiva förmåga att bearbeta information och göra rationella val baserat på informationen.

Miljöpolitiska styrmedel försöker antingen begränsa oönskade alternativ eller främja önskvärda sådana. Till exempel kan miljöskadliga alternativ helt förbjudas (exempelvis freon i kylskåp) eller göras dyrare relativt mer miljövänliga alternativ (skatt på koldioxid). Det finns olika sätt att främja önskvärda alternativ, exempelvis att framhäva vad dessa alternativ är (genom informationskampanjer och ekomärkning) eller att göra dem billigare i förhållande till skadliga (till exempel genom subventioner av solpaneler). Sammantaget kan beslutsfattarnas traditionella verktyg delas in i tre övergripande grupper: administrativa styrmedel, ekonomiska styrmedel och informativa styrmedel. ${ }^{9}$ Några exempel inom respektive grupp redovisas i Tabell 1.

Tabell 1: Grupper av politiska styrmedel inom miljöpolitiken och exempel inom respektive grupp

\begin{tabular}{|c|c|c|}
\hline Administrativa & Ekonomiska & Informativa \\
\hline Gränsvärden & Avgifter & Ekomärkning \\
\hline Långsiktiga avtal & Bidrag/subventioner & Opinionsbildning \\
\hline Miljöklassning & Certifikatsystem & Rådgivning \\
\hline Normer & Marknadsbaserade handelssystem & Upplysning \\
\hline Producentansvar & Pantsystem & Utbildning \\
\hline Reglering & Skatteavdrag & \\
\hline Tekniska krav & Skatter & \\
\hline Övervakning/kontroll & Sanktioner & \\
\hline Förbud & Böter & \\
\hline
\end{tabular}

Källa: Copenhagen Economics baserat på Konjunkturinstitutet (2012).

8 Detta kallas också negativa externa effekter eller externaliteter och är en klassik orsak till reglering. En konsument som skräpar ner betalar exempelvis inte de fulla kostnaderna av sitt handlade då samhället betalar kostnaderna för exempelvis gatustädning. Ett ytterligare exempel är koldioxidutsläpp som skapas i samband med till exempel konsumtion av bränsle eller produktion av el via kolkraftverk eftersom utsläppen inte betalas direkt av förorenaren och därmed inte beskattas.

${ }^{9}$ Ibland räknas forskning och utveckling till politiska styrmedel. 
I många fall agerar konsumenter också ekonomiskt rationellt. Människor svarar generellt på högre priser med att köpa mindre av den dyrare produkten, och det är självklart att individer behöver information (till exempel om miljöeffekter) för att fatta väl underbyggda beslut. Det finns dock också undantag, exempelvis på när människor gör både mer eller mindre än vad som motiveras utifrån nationalekonomiska teorier. Undersökningar har exempelvis visat att människor ofta känner till möjligheter för, sätter värde på, har positiva attityder till, och ofta har för avsikt att fatta miljömässigt hållbara konsumtionsval, vilket enligt teorin borde göra att de handlar i enlighet med dessa preferenser. I många fall leder dock inte avsikten att göra hållbara val till hållbara val i praktiken. ${ }^{10}$ Det finns också flera exempel på när individer gör samhällsnyttiga val utan ekonomiska incitament eller andra styrmedel. Ett exempel utanför miljöområdet är inbetalning av skatter, där svenska Skatteverket länge arbetat utifrån premissen att individer i högre grad svarar på sociala normer när de väljer att betala skatt eller inte, än exempelvis hot om ekonomiska sanktioner, se Box 1.

Hur kan vi förklara denna typ av beteenden och vilka konsekvenser får de för politiska beslut som syftar till att främja hållbara konsumtionsmönster? Beteendevetenskapen, och beteendeekonomin, har vissa svar på dessa frågor.

${ }^{10}$ Exempelvis uppger mer än fyra av fem nordiska medborgare att det är bekymrade över miljön, medan endast en av tio uppger att de regelbundet köper miljövänliga produkter. Källa: Mont et al. (2014). 


\section{Box 1. Beteendeekonomi och skattefusk}

En rapport från Skatteverket visar tydligt att ekonomiska incitament och risken för upptäckt och straff har en mindre betydelse än normer och moral för huruvida människor skattefuskar eller inte. Detta går emot tidigare ekonomisk forskning om skattebetalarnas beteenden, där man i regel antar att skattefusk är en funktion av upptäcktsrisk och straff i form av skattetillägg. I ekonomiska termer bygger synsättet på rationalitet, enkelt definierat som "en kalkyl över vinster och kostnader". Det finns vinster att hämta om fusket lyckas, och kostnader (straff) uppstår om det misslyckas. Exemplet nedan visar hur skattebetalare antas gör en sådan kalkyl enligt traditionella modeller.

Anta att den skatt en individ ska betala är 1000 , och att straffet om skatten inte betalas är ett tillägg på $40 \%$. Vid upptäckt om fusk måste individen därmed betala 1400 (den skatt man skulle betala plus tillägg på 400). Då risken för upptäckt alltid är mindre än 100 \% jämför individen i ramverket 1000 (vinsten om man inte betalar skatt) med 1400 gånger upptäcktsrisken. I det här fallet måste upptäcktsrisken vara över 71 \% för att individen ska välja att betala skatt (1 000/1 400).

Skattebetalare i hela världen fuskar mindre än vad dessa modeller förutspår. Undersökningar visar att vissa aldrig fuskar även om risken för upptäckt är obefintlig. Skatteverkets rapport pekar ut flera förklaringar till beteendet, varav en viktig sådan var skuldkänslor och risken för social stigmatisering. Detta hade en betydligt större avskräckande effekt än både upptäcktsrisk och straff. Indirekt gjorde det också att upptäcktsrisken fick större betydelse än straffet, då den är kopplad till risken för social stigmatisering. Den upplevda rättvisan hos ett skattesystem hade också betydelse för inbetalning av skatter, och om en person anser att skattefusk är allmänt spritt är det mer troligt att personen också kommer att fuska.

Det ekonomiska egenintresset avförs inte som betydelselöst i studien - det har en betydelse, särskilt för företag. Slutsatsen som dras är att det ekonomiska egenintresset är en faktor som balanseras av andra faktorer.

Källa: Skatteverket (2005). 


\subsection{Varför beter vi oss inte alltid som ekonomerna tror?}

Genom att studera människors faktiska beteenden, ofta under lång tid, och ställa dessa i kontrast till teoretiska antaganden om hur människor "borde" bete sig bidrar beteendevetenskapen med kunskap som kan vara avgörande för huruvida politiska insatser av olika slag lyckas eller inte.

Vad denna forskning sammanfattningsvis har visat, i kontexten hållbar konsumtion, är att "gap" i konsumenters medvetande hindrar dem från att fatta hållbara beslut. Gapen sammanfattas vanligtvis i tre kategorier: kunskaps-handlingsgap, värderings-handlingsgap och avsikts-handlingsgap. ${ }^{11}$ Kunskaps-handlingsgap innebär att konsumenten har information om konsekvenserna av ohållbar konsumtion, men ändå väljer att inte handla i enlighet med informationen. Värderings-handlingsgap innebär att konsumenter värderar hållbar konsumtion högt, men trots det väljer en ohållbar konsumtion. Avsikts-handlingsgap innebär att konsumenter har kunskap och värderar ett visst beteende i linje med målbilden, men ändå väljer att handla annorlunda.

Det finns en uppsjö möjliga förklaringar till detta, och en stor och växande forskningslitteratur på området - ett viktigt bidrag beskrivs i Box 2. Många förklaringar stämmer väl överens med sådant som känns igen från vardagen: det är ansträngande att göra saker, lätt att skjuta på dem och lätt att glömma - även om vi vet att vi borde. Många beslut är i grunden komplexa med ett stort antal val, osäkert utfall och många olika önskemål som ska balanseras. Andra är rutinmässiga och vi tänker inte över vad vi gör. Vi påverkas av vad våra vänner tycker och gör, vad vi tror är accepterat i samhället, vad vi tror väntas av oss etc. Det är på det hela taget många olika faktorer som spelar in när människor bestämmer sig för att agera eller inte agera miljövänligt i olika situationer.

\footnotetext{
11 Författarnas översättning från engelskans knowledge-action gap, value-action gap och intention-action gap. Baserat på Fredricks et al. (2015).
} 


\section{Box 2. Två tankesystem}

Ett viktigt bidrag till forskningen om individers beteenden har gjorts av Daniel Kahneman och Amos Tversky, där Kahneman 2002 fick Sveriges Riksbanks pris i ekonomisk vetenskap till Alfred Nobels minne (Nobelpriset i ekonomi) för deras forskning om hjärnans två system: System 1 fattar snabba beslut baserat på automation och intuition, och system 2 fattar långsamma, rationella beslut baserat på tillgänglig information. Skillnaden i de två tankesystemen och när de används har visat sig vara bidragande orsaker till konsumenters beteende.

De kognitiva processer som genomförs med hjälp av system 1 kan beskrivas som snabba och intuitiva. System 1 använder exempelvis tumregler och mentala genvägar för att klara våra dagliga rutiner, såsom att duscha och cykla, vilket underlättar för vår hjärna som inte behöver anstränga sig för att analysera varje given (rutinmässig) situation.

System 2 kräver en mycket större och medveten mental ansträngning, och förlitar sig på analyser med många parametrar. Det är också mot system 2 som de flesta konsumentorienterade styrmedel inom miljöpolitiken riktar sig, genom att exempelvis tillhandahålla information.

Ibland gör system 1 val som lämpar sig för system 2. I det fallet analyseras inte alla relevanta parametrar, utan beslutet baseras i stället på exempelvis vad man valde i en liknande situation tidigare, vad ens vänner valt eller vilket beslut som framhävs av den som utformat valsituationen. Detta är en av förklaringarna till varför somliga insatser mot konsumenter inte får önskvärda resultat.

Källa: Kahneman (2011).

Vid konsumtion av elektronikprodukter uppvisar konsumenter olika typer av beteenden. Köpen är ofta relativt överlagda, medan användningen av produkterna typiskt är mer rutinmässig och vanestyrd. Den energikonsumtion som uppstår när vi använder elektronik uppstår exempelvis i situationer när vi är upptagna med annat, och tar liten del av våra vardagliga tankar. Vid det faktiska köpet behöver en konsument ta flera beslut, såsom huruvida denne ska ha en ny eller en begagnad vara. Om konsumenten redan äger en vara av samma slag som inte längre behövs måste personen också avgöra vad som ska göras med denna. Dessutom sker en annan process vid beslut om återvinning, med andra steg.

En försvårande faktor i beteendeanalysen är att processerna ser olika ut beroende på vilken typ av elektronik som konsumeras. Exempelvis är informationssökningen annorlunda vid köp av elektriska leksaker, jämfört vid köp av en ny tvättmaskin. Stor hemelektronik, till exempel vitvaror, 
återvinns troligtvis i högre grad än smått elavfall eftersom företag som installerar nya kylskåp ofta erbjuder som tjänst att ta med det gamla. Mobiltelefoner har större sannolikhet att hamna i en byrålåda eller soptunna.

Fokus för beteendeekonomin är att identifiera vilka faktorer som spelar in samt när, var och hur dessa beteendemönster uppstår samt vad som kan göras för att anpassa politiska styrmedel till dem. Vi går i nästa avsnitt igenom några sådana avvikelser som kan vara relevanta för hållbar konsumtion med särskilt fokus på elektronikkonsumtion. I den efterföljande pilotstudien går vi djupare in på en specifik kategori: konsumtion av mobiltelefoner i åldersgruppen 19 till 28 år.

\subsection{1 "Förutsägbart irrationella" beteenden vid elektronikkonsumtion}

I de fall avvikelser från ekonomisk rationalitet går att kartlägga och förstås kan konsumenter ses som "förutsägbart irrationella". Med detta menas att konsumenter beter sig irrationellt när de inte svarar på priser och valmöjligheter enligt vad som förväntas, men att avvikelsen går att förutspå. Det irrationella beteendet är alltså förutsägbart, och går därmed att motverka. ${ }^{12}$

Människor uppfattar saker som mindre värdefulla eller betydande om de sker längre fram i tiden (temporal diskontering) eller längre bort geografiskt (rumslig diskontering), så kallad psykologisk diskontering. Det innebär exempelvis att vi lägger mer vikt vid de kortsiktiga konsekvenserna av våra beslut än de långsiktiga. När det gäller konsumtion innebär det att konsumenter undviker åtgärder som är kostsamma på kort sikt (till exempel att lägga tid och pengar på att köpa nya energieffektiva apparater eller anstränga sig för att byta elleverantör), trots att det skulle innebära långsiktiga vinster (till exempel minskade elräkningar). För elektronikkonsumtion kan detta innebära att man köper en billigare produkt som ger lägre kostnader på kort sikt, men högre på lång sikt i form av exempelvis högre reparationskostnader, vattenförbrukning eller energianvändning.

Människor tenderar att behålla status quo, det vill säga hålla sig till standardinställningar eller skjuta upp beslutsfattandet helt, särskilt när mängden information eller komplexiteten ökar. Till exempel tenderar människor att acceptera förinställda alternativ, även om andra alternativ

12 Terminologi enligt Thaler \& Sunstein (2008). Se Bilaga A för en mer utförlig lista på beteenden från litteraturen. 
kan ge bättre utfall. För elektronik kan det innebära att man exempelvis köper samma varumärke på sin tvättmaskin som man tidigare gjort eftersom det beslutet kan ses som "säkert".

Människor är starkt beroende av rutiner och vanor, det vill säga beteenden som vi inte aktivt reflekterar över. Enligt Verplanken \& Wood (2006) är ca $45 \%$ av våra vardagliga handlingar egentligen inte val, utan vanor eller rutiner. Beslut som tas enligt förbestämda mönster kallas $\mathrm{i}$ marknadsföringslitterauren för beslut med "låg grad av delaktighet", det vill säga beslut som involverar begränsad medveten överläggning. En studie av Knussen \& Yule (2008) fann att personer som egentligen ställer sig positiva till källsortering ändå fortsätter att slänga återvinningsbart avfall i de vanliga soporna, av gammal vana. När det gäller energikonsumtion är rutiner och vanor antagligen viktigare att analysera när elektroniken används och inte vid själva köpet, eftersom detta som nämnts ofta är relativt överlagt.

Människor nöjer sig ofta med "tillräckligt bra" snarare än "bäst". I stället för att ta reda på vad som är det bästa alternativet och välja detta nöjer sig många konsumenter med ett alternativ som ses som tillräckligt bra för att uppfylla behovet. Detta har bland annat identifierats för energimärkning. Figur 6 visar andelen konsumenter i Norge som köpte olika elektriska varor i energi klass $\mathrm{A}, \mathrm{A}+$ och $\mathrm{A}++$, där det sistnämnda alternativet använder minst energi. Resultaten visar att de flesta konsumenter som deltog i studien valde att köpa produkter som tillhör den tredje bästa energiklassen, kanske för att en A-märkning ses som "tillräckligt bra".

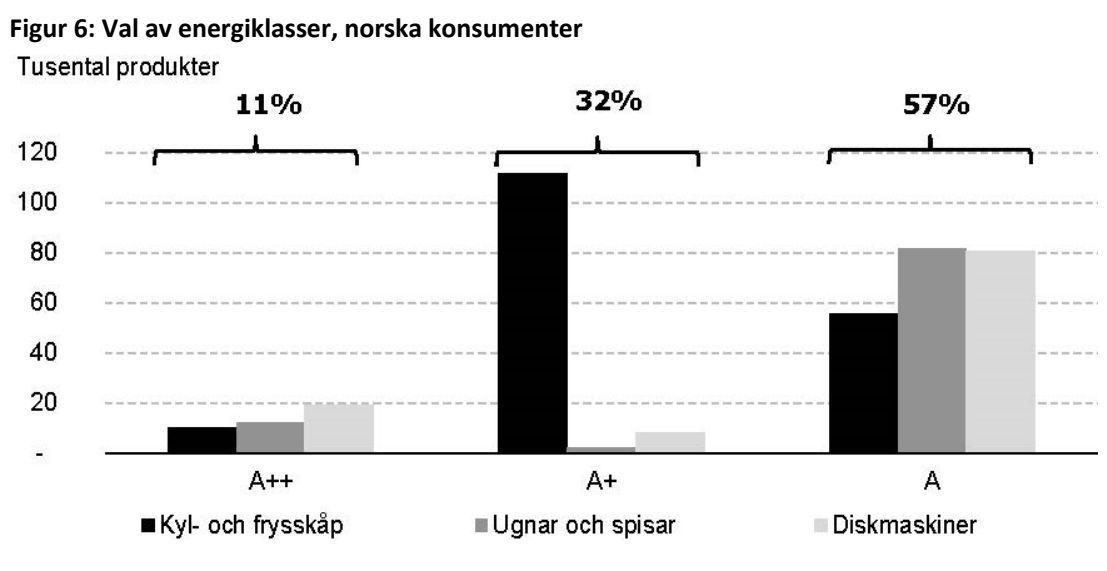

Källa: Norwegian Water Resources and Energy Directorate (2013).

När någon väljer ett "tillräckligt bra" alternativ i stället för det bästa kan det till viss del bero på att personen är oförmögen att systematiskt bearbeta all 
tillgänglig information, eller att informationen är alltför komplex. I dessa fall väljer många det första tillgängliga alternativ som uppfyller minimikraven. Detta kan också leda till att man helt ignorerar information. Exempelvis kan energi- och hållbarhetsmärkning som är alltför komplex ignoreras av mottagaren. Vid återvinning av elektronik måste det vara lätt att utläsa vad som ska läggas i respektive insamlingskärl, för annars kan människor struntar i att lägga produkten i rätt fack även om de har motivation att göra det. En studie av Konsumentverket i Sverige visar att informationsbrist kan vara en bidragande orsak till ohållbart beteende bland konsumenter, se Figur 7. Nästan hälften av respondenterna instämmer i påståendet att det finns för många valsituationer för att de ska kunna hålla sig informerade och göra miljömedvetna val. Hälften stämmer också in på påståendet att miljövänliga val tar mer av deras tid än önskvärt.

Figur 7: Möjlighet att agera miljövänligt

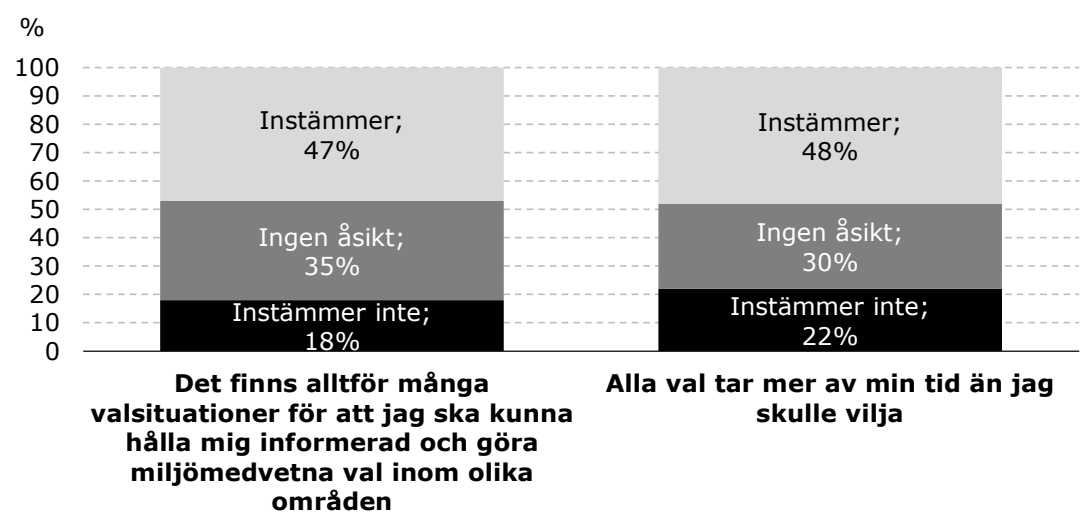

Not: Genom en enkätundersökning via post angav 765 personer om och hur de tar hänsyn till miljön i samband med konsumtion av livsmedel, resor, vitvaror och hemelektronik. Personerna fick ta ställning till i vilken utsträckning de instämmer med ett antal påståenden, från 1 = instämmer inte alls, till 5 = Instämmer helt och hållet.

Källa: Synovate (2009).

Människor gör sociala jämförelser, följer andras beteende, och anpassar sig till sociala normer, det vill säga de explicita och implicita riktlinjer inom en grupp eller ett samhälle som anses normala eller önskvärda. Två typer av normer kan definieras: föreskrivna respektive deskriptiva normer. Föreskrivna normer innefattar en moralisk implikation, det vill säga vad som bör göras och vad som inte bör göras. Deskriptiva normer relaterar till hur andra beter sig, det vill säga det "normala" sättet att göra något. Normer återspeglas bland annat i en tendens att "följa med flocken" (flockbeteende) och "hoppa på tåget" ("the bandwagon effect"). Människor tenderar också 
att göra sociala jämförelser och utvärdera prestationer, ägodelar och välbefinnande i förhållande till andra snarare än i absoluta termer. Detta är relevant för elektronik där till exempel mobiltelefoner är en statusvara, och många vill ha senaste modellen eftersom alla andra har den. Varumärkesbyggnad och marknadsföring bland företag som anspelar på normer kan också öka konsumtionen av elektronikvaror bortom vad som är hållbart. Vidare har normer en stark påverkan på tendenser att agera hållbart: om man tror att andra engagerar sig för hållbar konsumtion är man mer benägen att göra det själv också. Dessutom, om man tror att andra inte gör det är man själv mindre benägen att göra engagera sig.

Människor använder förtroende som en enkel tumregel för att fatta beslut, där trovärdighet beror på uppenbar kompetens och erfarenhet (kompetensbaserat förtroende) samt upplevd öppenhet, ärlighet och omtanke om andra (integritetsbaserat förtroende). Till exempel kan effekten av informationskampanjer ofta bero på den upplevda trovärdigheten hos kommunikationskällan. Om källan till ett meddelande verkar opålitlig, orättvis eller inkompetent kan människor vara försiktiga eller skeptiska och antingen ignorera eller reagera defensivt på informationen. Det här kan påverka effektiviteten i exempelvis informationskampanjer - om mottagaren inte betraktas som trovärdig minskar effektiviteten. Det finns också möjlighet att det helt slår tillbaka, och att man inte litar på att hållbara varor faktiskt är hållbara. Konsumenter verkar generellt ha litet förtroende för medier och företag som informerar om hur man bäst agerar miljövänligt, men högt förtroende för forskare och konsument- och miljöorganisationer, se Figur 8. Det innebär att kampanjer som exempelvis har en miljöorganisation som avsändare troligtvis får större genomslag än motsvarande med ett företag som avsändare. 
Figur 8: Förtroende för aktörer som levererar information om hur man agerar miljövänligt

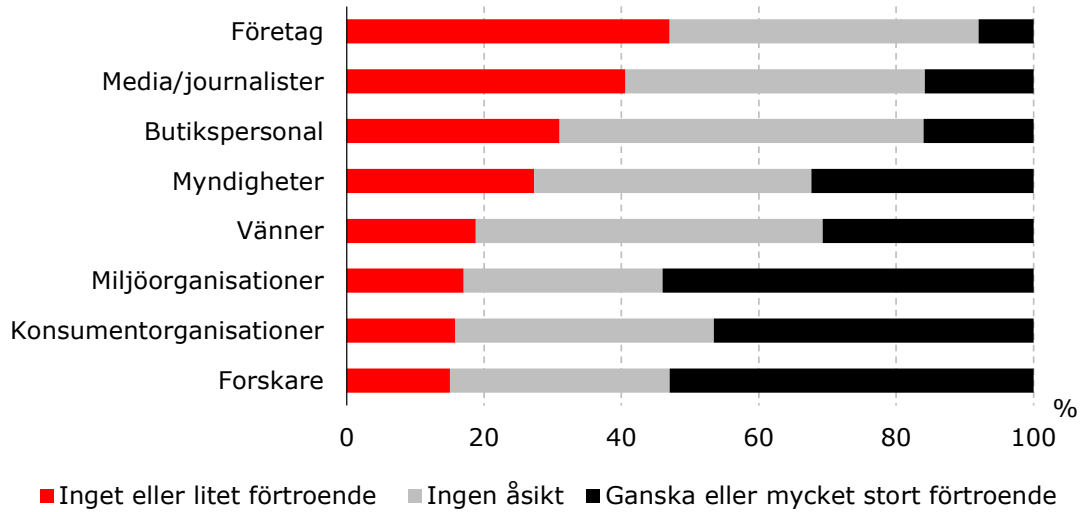

Not: Genom en enkätundersökning via post angav 765 personer om och hur de tar hänsyn till miljön i samband med konsumtion av livsmedel, resor, vitvaror och hemelektronik. Personerna fick svara på frågan: "Vilket förtroende har du för information om hur man agerar miljövänligt från följande grupper och organisationer?" och välja från 1 = "Mycket litet" till 5 = "Mycket stort".

Källa: Synovate (2009).

Företag har en lång tradition av att tillämpa olika strategier som utnyttjar beteenden och mentala genvägar hos konsumenter för att påverka inköpsmönster och nivåer. Mont et al. (2014) beskriver hur företag varit pionjärer i att använda insikter från forskning om konsumentbeteende, exempelvis genom att utveckla kommunikationsstrategier och marknadsföringskampanjer för att forma köpbeteenden genom layout och butiksinredning.

I ökande grad används den här kunskapen också för att utforma politiska styrmedel. Insikterna från beteendeekonomin underlättar för beslutsfattare att förstå mänskligt beteende och de faktorer som påverkar beteendeförändring, men också för att ta fram strategier för att främja hållbara konsumtionsmönster. Den möjlighet som studeras i den här rapporten är användning av nudging - att utan tvång "puffa" konsumenter mot mer hållbara konsumtionsval. 


\subsection{Nudging kan användas för att hjälpa konsumenter göra hållbara val för elektronikkonsumtion}

Beslutsfattare kan kartlägga och studera de beteenden och mentala genvägar konsumenter tar för att på så sätt nudga ("puffa") konsumenter i en hållbar riktning. Thaler \& Sunstein (2008) definierar en nudge på detta sätt:

"[En nudge är] en aspekt av valarkitekturen som förändrar människors beteende på ett förutsägbart sätt utan att förbjuda eventuella tillval eller avsevärt ändra deras ekonomiska incitament. För att räknas som en ren nudge måste insatsen vara enkel och billigt att undvika."13

En nudge kan därför vara sättet att utforma en valsituation och sättet att presentera olika alternativ (även kallat valarkitekturen), för att förändra människors beteende på ett förutsägbart sätt utan att eliminera deras möjligheter eller ändra underliggande incitament genom att till exempel ändra priserna. Målet med att introducera en nudge är att hjälpa individer att fatta de beslut som de själva skulle gjort om de varit uppmärksamma, haft fullständig information och fullständig självkontroll.

Som nämnts finns det likheter mellan nudgingliknande insatser bland företag och nudging som genomförs av offentliga aktörer, men samtidigt finns en fundamental skillnad. Företag svarar på efterfrågan från konsumenter (och styr den till viss del) i en riktning som medför fördelar för företagen, medan konsumentorienterade styrmedel (med hjälp av nudging) syftar till att styra denna efterfrågan mot val som är fördelaktiga för samhället, se Box 3.

Box 3. Nudging eller marknadsföring?

from here

to

sustainability

Nudgingliknande insatser bland företag och nudging som genomförs av offentliga aktörer har mycket gemensamt, men en grundläggande skillnad mellan dem är att nudging syftar till att hjälpa människor att göra val som är fördelaktiga för samhället. Marknadsföring däremot lockar folk till val som i första hand medför fördelar för företagen. Exempelvis reagerar marknaden i allt

13 Översättning av Mont et al. (2014) s. 15. 
högre utsträckning på konsumenters efterfrågan på hållbarhet genom att erbjuda ekologiska och etiska produkter, men den hade reagerat på samma sätt om konsumenter efterfrågat ohållbara produkter. Nudging syftar i stället till att förbättra eller komplettera styrmedel som uppmuntrar hållbart beteende. Med andra ord: företag svarar på efterfrågan, och konsumentorienterade styrmedel (med hjälp av nudging) syftar till att styra den.

Ett tydligt exempel på hur företag använder nudging-liknande insatser kan ses i en ny kampanj från Clas Ohlson. Företaget har nyligen utvecklat konceptet "From here to sustainability", som bland annat syftar till att belysa de av företagets produkter som klassificeras som hållbara genom att sätta ut gröna pratbubblor i sina butiker och på sin webbplats. Eftersom efterfrågan på hållbara produkter ökar är det antagligen fördelaktigt för Clas Ohlson att visa att de säljer sådana varor, utöver den goodwill detta skapar. Om konsumenter i stället endast hade efterfrågat "ohållbara" varor (och om det inte funnits något mervärde i form av exempelvis goodwill för företaget att agera hållbart) hade Clas Ohlson dock enligt grundläggande företagsekonomiska principer lika gärna styrt konsumenter mot dessa varor. Exemplet visar också att det inte nödvändigtvis finns en motsättning mellan företags affärsmodeller och politikens vilja att styra konsumenter mot mer hållbara val - i stället kan företag (under rätt omständigheter) agera draghjälp i utvecklingen mot mer hållbar konsumtion. 
I denna rapport använder vi begreppet nudging för att beskriva en avsiktlig ändring i valarkitekturen, med målet att framkalla ett visst resultat. Rapportens huvudsyfte är inte att bidra till den rika diskussionen om lämpligheten av nudging och metodens etiska dimensioner. Vi sammanfattar och diskuterar endast kort de vanligast förekommande föroch motargumenten i debatten, se Box 4.

\section{Box 4. Etiska aspekter av nudging}

En del av den kritik som riktas mot nudging gäller huruvida individer som är utsatta för nudging faktiskt har ett fritt val, om beslutsfattare kan påverka dem på ett medvetet och förutsägbart sätt. Exempelvis framför Martaeu et al. (2011) att nudging kan användas som ett medel för att manipulera människor. Annan kritik handlar om att (somliga) nudges riktar sig mot mekanismer som människor inte är medvetna om, och att välinformerade grupper har bättre möjlighet att uppfatta och identifiera nudges. Om de medvetna individerna kan undvika och till och med dra fördel av insatserna kan nudging ses som odemokratiskt.

Mycket av denna kritik går dock också att rikta mot traditionella styrmedel. Välinformerade individer har ett övertag över sämre informerade individer även vid beslut som påverkas av skatter och restriktioner. Det kan till och med vara så att värdet av att vara välinformerad vad gäller skatter och restriktioner är betydligt större än värdet av att vara välinformerad om nudging, eftersom det har visat sig väldigt svårt att stå emot sitt irrationella beteende och nudges trots att man är välinformerad (Kahneman, 2011). Nudging kan också ses som ett mindre intrång i personens valsituation och självbestämmande än exempelvis förbud mot en vara, eller fördyring genom skatter. Enligt en strikt definition av begreppet begränsar ju inte nudging individens frihet att göra specifika val eftersom det inte ändrar incitamentsstrukturen eller medför restriktioner eller förbud. En fördel jämfört med traditionella styrmedel är också att olika nudges kan testas i kontrollerade experiment eller i liten skala innan de implementeras fullt ut. Det är sällan möjligt vid förändringar av andra styrmedel.

Slutligen är - som tidigare nämnts - en valsituation aldrig neutral, utan individer påverkas alltid av omgivande faktorer på olika sätt. Information är inte något man automatiskt har, utan det presenteras på ett eller annat sätt, och att vara informerad är en förutsättning för att kunna välja överhuvudtaget. Frågan är därmed inte om information ska presenteras på ett visst sätt, utan vem som bestämmer hur den presenteras. Den som gör detta har såklart makten att välja exempelvis vilken information som utelämnas. Men alternativet är i många fall att lämna inramningen åt slumpen, vilket inte nödvändigtvis ger ett resultat som konsumenten själv skulle välja. Dessutom går miljöpolitik inte ut på att styra mot vad individen skulle välja, utan mot ett samhälleligt effektivt utfall. Tekniskt 
sett ska nudging förenkla för individer att välja i linje med sina faktiska preferenser, men som en del av ett större styrmedelspaket kan nudging också vara ett hjälpmedel för att uppnå den politiska målsättningen.

Oavsett den etiska aspekten finns en risk för att nudging som metod kan få ett bakslag om det framställs som ett verktyg som manipulerar folk. Nudging är antagligen okontroversiell om den exempelvis går ut på att göra framställningen av information transparent, och om den ser till att individer får den information som behövs för att kunna fatta informerade beslut. Andra typer möter dock troligtvis mer motstånd.

Källa: Copenhagen Economics baserat på Thaler \& Sunstein (2008), Kahneman (2011), Martaeu et al. (2011), Hansen \& Jespersen (2013), Sunstein \& Reisch (2013).

\subsubsection{Användning av nudging}

Olika nudges har med framgång använts av myndigheter, till exempel för att öka individers pensionssparande (Thaler \& Sunstein, 2008) och för att minska nedskräpning (Mont et al., 2014). Thaler \& Sunstein (2008) menar att nudging är lämpligt när något av följande kriterier är uppfyllda för konsumenters val:

- Valen har fördröjda effekter.

- Valen är komplexa eller förekommer sällan, och chansen att lära sig är därmed begränsad.

- Återkoppling på utfallet är inte möjlig.

- Relationen mellan val och utfall är tvetydig.

Elektronik är sällanköpsvaror, vilket innebär att det är ganska långa perioder mellan köpen. Kombinerat med korta innovationscykler är det vanligt att den information man har om en viss produkt ofta är utdaterad vid köptillfället, och att man måste söka ny information vid ett köp. Effekterna av ett köp kan ses som fördröjda på så sätt att en stor del av kostnaderna uppstår vid användningen, till exempel kostnader för vatten till en diskmaskin eller elanvändningen från en lampa. Detsamma gäller för återvinning av elektroniken - det sker sällan, konsumenten făr svag återkoppling och kan i vissa fall vara osäker på om det faktiskt ger effekt på miljön att återvinna elektronik. 
Vi känner inte till några vetenskapliga experiment på nudging $\mathrm{i}$ samband med elektronikkonsumtion. Det finns dock en hel del litteratur på angränsande områden som kan vara intressant och eventuellt appliceras på elektronik. Vi går här igenom de nudges vi ser som mest relevanta för hållbar konsumtion, med särskilt fokus på elektronik.

Hur information påverkar en konsuments beteende beror inte bara på faktamässigt innehåll, utan också på utformning och presentation. Det är viktigt att förenkla och rama in information, samt att ge information $i$ rätt tid och på rätt plats. På så sätt går det att motverka beteenden såsom psykologisk diskontering, människors önskan att behålla status quo och tendensen att nöja sig med "tillräckligt bra" snarare än "bäst". Mycket av den nudging som undersökts och använts i olika sammanhang bygger just på att förenkla och ge information.

Miljömärkningar är ett exempel på hur rätt inramning av information kan påverka en konsuments beteende, och exempelvis Svanenmärkningen förmedlar information som direkt påverkar en konsuments köpbeslut. Samtidigt kan märkningens utformning och presentation ge upphov till andra, mer undermedvetna beteendeförändringar om de till exempel associeras med en viss självbild.

Kallbekken et al. (2012) undersöker om försäljningen av energiintensiva kylskåp och torktumlare minskar när en produkts prisinformation kompletteras med information om energianvändning. Studien visar en signifikant effekt för torktumlare men inte för kylskåp. Synovate (2009) visar också hur valet av information kan påverka en konsuments köpbeteende: I en undersökning av hur märkning påverkar köp av hemelektronik uppgav drygt tre av fyra (77\%) att tydlig information om en produkts garanterade livslängd i stor utsträckning skulle få dem att välja mer miljövänliga hemelektronikprodukter.

I linje med dessa resultat skriver Thaler \& Sunstein (2008) att energimärkning kan göras ännu effektivare om produktens livstidskostnad sätts ut i kronor, och att valet av energiklasser i produktutbudet kan påverka konsumentens beslut.

Den fysiska miljön som en konsument befinner sig i kan på liknande sätt ge upphov till ett visst beteende, och framför allt motverka rutiner och vanor. Denna nudge kan vara speciellt relevant för konsumtion av små och billiga elektronikprodukter som köps oftare och mer impulsivt, och då kan en välplanerad valarkitektur påverka konsumenters val i en mer miljövänlig riktning. Också återvinningsbeteendet kan främjas genom förändringar i den fysiska miljön. I John et al. (2013) framhävs vikten av en genomtänkt fysisk miljö för återvinning för att uppmuntra ett positivt beteende. 
Det är vanligt att konsumenter väljer standardalternativ framför att själva ta ett aktivt beslut. Därför kan val av standardalternativ fungera som en nudge när det gäller beteenden såsom önskan att behålla status quo, rutiner och vanor, och tendensen att välja "tillräckligt bra" snarare än "bäst". Utskriftsalternativ, organdonation och pensionssparande är exempel på områden där valet av standardalternativ har stark inverkan på utfallet. För energiförbrukning är valet av standardalternativ delvis inkluderat i ekodesigndirektivet, vilket bland annat innehåller krav på att produkter har en energistyrningsfunktion som ser till att automatiskt ställa produkten i ett lågeffektsläge när den inte används.

Normbrytning uppmärksammas ofta som något negativt av omgivningen, och därför tenderar konsumenter att snabbt anpassa sig till sociala normer. Sådana normer fungerar som en vägledning när tydliga instruktioner saknas, och ger konsumenter en anledning att reagera på jämförelser med andra människor. Exempelvis har ett antal studier visat att grannar påverkar varandra när det gäller insatser för återvinning och energisparande.

Ibland kan människors beteenden skapa en oönskad positiv effekt ur miljöhänsyn. Ett exempel är när konsumenter som egentligen inte har en preferens för miljövänligt väljer miljömärkta varor på grund av ett större utbud eller bättre produktplacering. Detta är i linje med Barkman (2014) som identifierar både barriärer till hållbar konsumtion, men också "broar" till handling som kan uppstå när konsumenter inte agerar enligt sina preferenser.

Flera nudges går hand i hand och kan vara svåra att urskilja analytiskt. De kan också användas tillsammans för att uppnå en önskad effekt. Exempelvis kan information presenteras på ett sätt som anspelar på sociala normer, och på så sätt ge upphov till beteendeförändringar.

För att identifiera i vilken utsträckning personer som på något sätt arbetar med elektronikkonsumtion eller hållbar konsumtion i Norden använder beteendeekonomiska insikter har vi genomfört en intervjustudie, varav delar sammanfattas i Box 5. Resultaten visar att användningen verkar begränsad, men att många ställer sig positiva till att använda nudging eller generella resultat från beteendeekonomisk forskning. 


\section{Box 5. Potentiella utövare har liten praktisk erfarenhet av nudging}

Copenhagen Economics vill undersöka hur nudging och beteendeekonomi används för att påverka nordiska konsumenter i hållbar riktning, och därför har vi intervjuat personer som på något sätt arbetar med konsumtion, insamling eller återvinning av elektronik i Sverige, Finland och Danmark.

En av de viktigaste slutsatserna från intervjustudien är att intervjupersonerna mycket sällan använder nudging och generella insikter från beteendevetenskap. Flera anser att användningen av nudging för hållbar konsumtion av elektronikkonsumtion inte är mogen, och att det finns större behov av exempelvis fysiska möjligheter att återanvända och återvinna elektronik på ett bra sätt. Styrmedel av ekonomisk och administrativ typ spelar en viktigare roll här. Som diskuteras i kapitel 1 bör nudging i detta sammanhang eventuellt ses mer som ett komplement till traditionella styrmedel än som ett styrmedel i sig.

De flesta av intervjupersonerna är positiva till nudging, men påpekar att kunskapen och viljan fortfarande saknas i deras respektive organisationer. För att avhjälpa detta efterfrågar man ökad kunskap om nudging och dess användning. Somliga påpekar att det är viktigt att visa vilken skillnad nudging gör för att verktyget ska få ordentligt genomslag. Det är därför viktigt att strukturera nudges så att de går att utvärdera.

Det anges också i intervjuerna att de aktörer som ses som mest relevanta för nudging är kommuner eftersom de har praktisk kunskap om hur folk beter sig från exempelvis utformning av vägar och vårdtjänster. De har också närmare kontakt med konsumenter än exempelvis statliga aktörer, och kan därmed mer effektivt sätta in nudging när det ger mest effekt - en grundpelare i användningen av nudging.

Källa: Copenhagen Economics baserat på intervjuer med representanter för El-kretsen $\mathrm{i}$ Sverige, Samkommunen Helsingforsregionens miljötjänster HRM, Energimyndigheten i Sverige, Dansk Kompetencecenter for Affald (DAKOFA) och Karlstads kommun.

\subsection{Nudging snarare ett komplement än en helhetslösning}

Många menar att nudging bör ses som en del av ett större paket av styrmedel, där information och exempelvis skatter fortfarande utgör grunden för att förändra konsumenters beteenden. Nudging kan då vara ett komplement till eller överlappar med ingripanden som fokuserar på 
attityd- eller värdeförändring enligt Mont et al. (2014). Stockholm Environment Institute (2015) beskriver nudging som mer av en designprincip än ett eget styrmedel, och menar att det kan appliceras antingen genom information eller genom exempelvis fysisk infrastruktur. Styrkan bedöms ligga i att nudging förstärker andra verktyg och insatser.

Enligt beskrivningen av nudging, till exempel av Thaler och Sunstein (2008), ska en nudge hjälpa individer att fatta de beslut som de själva skulle gjort om de varit uppmärksamma, haft fullständig information och fullständig självkontroll (det vill säga beslut som tas genom logiska överväganden och inte genom exempelvis mentala genvägar och tumregler). Detta beskrivs också ofta som styrkan med nudging - att insatsen hjälper människor fatta rationella beslut samtidigt som den är lätt att undvika om så önskas. Men hållbar konsumtion är inte nödvändigtvis ett rationellt val för konsumenter. Det kan till exempel ses som rationellt för konsumenter att inte vilja betala extra för att en elektronikprodukt är skrotningsvänlig eftersom de inte har någon direkt privatekonomiskt vinning av detta. Kostnaden för skrotning (eller att produkten hamnar i naturen i stället) är en externalitet för konsumenten som denna inte sätter ett pris på. För att internalisera kostnaden krävs fortfarande andra styrmedel såsom skatter. Beteendeekonomi och nudging dock kan med stor sannolikhet också vara ett effektivt komplement till andra styrmedel. Till exempel kan ekonomiska incitament förändras genom en skatt, och en nudge kan användas för att belysa att detta ekonomiska incitament har ändrats.

För att nudging ska bidra till mer hållbar konsumtion måste konsumenterna efterfråga hållbara produkter. Det finns en mängd konsumentorienterade insatser som påverkar detta, genom att till exempel informera om den miljöskada som uppstår av konsumtion av vissa varor. Men så länge betalningsviljan inte är hög nog fungerar inte nudging som ett styrmedel (enligt vedertagen definition). Det är alltså knappast möjligt för nudging att verka i ett vakuum. Däremot är nudging ett användbart styrmedel när det finns en vilja att agera hållbart som inte speglas av det faktiska beteendet. 


\section{Experiment av konsumtion av mobiltelefoner bland unga}

\section{Kapitlets innehåll}

I det här kapitlet gör vi en beteendekartläggning över ungas konsumtion av mobiltelefoner i syfte att identifiera oavsiktliga beteenden eller beteendehinder som hämmar hållbar konsumtion. Ett antal observationer talar för att så är fallet, och att det därmed finns utrymme för nudging. Till exempel noterar vi att relativt många ungdomar väljer att köpa en ny telefon när den gamla är trasig, utan att först undersöka om den istället skulle gå att reparera. Vi noterar också att unga när de köper en ny telefon ofta rutinmässigt går till den butik där de köpte sin gamla. En ytterligare intressant observation är att unga uppvisar en viss miljömedvetenhet och betalningsvilja för "gröna" telefoner samt leasing-tjänster.

Vi genomför i en pilotstudie två kontrollerade experiment som testar effekten av olika nudges på ungas konsumtionsbeslut. I det första experimentet undersöker vi hur nudging kan påverka beslutet att köpa en ny mobiltelefon när den gamla är trasig. Nudgen som undersöks är aktiv marknadsföring av två alternativa möjligheter: att reparera den gamla mobiltelefonen eller att köpa en begagnad telefon. I det andra experimentet undersöker vi hur nudging kan öka leasing och köp av "gröna" mobiltelefoner med hjälp av en decoy. De nudges vi provar riktas mot ett antal beteendehinder som kan uppstå i den valsituation som konsumenten står inför, såsom tillgänglighetsbias, psykologisk diskontering, sociala normer, förtroende och förlustaversion.

Resultaten visar att nudging kan ha en betydande effekt på ungas konsumtion av mobiltelefoner. Nudging i det första experimentet bidrar till att öka andelen konsumenter som väljer att reparera sin gamla telefon eller köpa en begagnad telefon. I det andra experimentet har nudgen en positiv effekt på andelen som väljer leasing framför att köpa en ny telefon, men ökar inte signifikant andelen som väljer att köpa en "grön" mobil. Då detta är ett pilotexperiment ska resultaten tolkas med försiktighet, men visar ändå att området har potential för vidare forskning. Ett viktigt bidrag är också att visa på vilken metod som kan användas för att kartlägga konsumenters beteende, och utveckla och testa nudges. 
I det här kapitlet beskrivs resultaten från en pilotstudie som undersöker hur nudging kan påverka mobiltelefonkonsumtion bland unga. Pilotstudien kartlägger översiktligt de beteenden som orsakar ohållbar konsumtion av mobiltelefoner i denna grupp, föreslår nudges som syftar till att förändra detta beteende hos individer utan att ändra eller begränsa deras alternativ eller incitament, samt testar föreslagna nudges i kontrollerade experiment. Syftet med pilotstudien är att ge en övergripande bild av ungdomars beteenden och möjligheten att påverka detta med nudging, för att visa var ytterligare forskning om nudging för hållbar mobiltelefonkonsumtion bland unga bör koncentreras.

I steg ett av pilotstudien kartlägger vi de beteenden som orsakar ohållbar konsumtion av mobiltelefoner. Målsättningen är att identifiera de beslutspunkter där det är möjligt att påverka individer mot mer hållbara konsumtionsmönster. Beslutspunkter kan vara exempelvis när man bestämmer sig för att köpa en ny telefon eller när man behöver laga sin gamla.

Utifrån identifierade beteenden designar vi i steg två lösningar, eller nudges. Designens syfte är att öka hållbar konsumtion, det vill säga att minimera försäljningen av mobiltelefoner, maximera användningen och se till att så mycket som möjligt går att återvinna när mobilen kasseras.

I steg tre testar vi slutligen föreslagna nudges i kontrollerade, så kallade randomiserade experiment. Syftet är att bedöma om den specifika nudgen har påvisbar effekt.

\subsection{Beteendekartläggning}

Vi fokuserar i pilotstudien på ungdomar i åldern 19 till 28 år. För att få det underlag som behövs för beteendekartläggningen gjorde vi inledningsvis en förstudie med 26 personliga intervjuer. Intervjuerna genomfördes i en dansk 3-butik, med ungdomar som köpt eller varit intresserade av att köpa en mobil. ${ }^{14}$ Syftet var att få en bild av beteendet bland ungdomar som nyligen övervägt möjligheterna de ställs inför vid valet av ny mobiltelefon, för att i enkätundersökningen fokusera på rätt frågor och för att identifiera de barriärer vi senare testar i experimenten.

Baserat på informationen i intervjuerna utarbetades en enkät för att få ytterligare underlag till experimenten. Den skickades till ca 440 personer i Danmark och Sverige i juni och juli månad 2015. I Danmark spreds enkäten med hjälp av föreläsare och undervisningsassistenter till studenter på

${ }^{14}$ Bilaga C innehåller en översikt av intervjufrågorna. 
Köpenhamns och Roskildes universitet genom att posta en länk på undervisningswebbplatsen och uppmana studenter att delta. I Sverige skickades enkäten ut till studenter genom en e-postlista i Copenhagen Economics ägo, och genom att kontakta professorer på Stockholms universitet och be dem sprida enkäten. Totalt svarade 127 personer. Vi exkluderades svar från personer utanför målgruppen (under 19 eller över 28 år), vilket gav sammanlagt 111 svaranden..$^{15}$ Samtliga respondenter ägde vid svarstillfället en mobiltelefon och hade i snitt ägt denna mobiltelefon i 3 år, se Tabell 2. Vidare hade $98 \%$ ägt en annan mobiltelefon innan den nuvarande. Omkring $85 \%$ av respondenterna hade en eftergymnasial utbildning medan $15 \%$ hade en gymnasieutbildning eller lägre. Värt att notera är att urvalsgruppen är mer högutbildad än populationen ungdomar i åldern 19 till 28 i nordiska länder i genomsnitt, vilket kan ge en snedvridning av resultaten. I en större studie bör en mer representativ urvalsgrupp eftersträvas.

Tabell 2: Deskriptiv statistik

\begin{tabular}{lrr} 
& Variabelvärde & Andel av svarande \\
Svarande & 111 & $100 \%$ \\
Kvinnor & 52 & $47 \%$ \\
Antal med mobiltelefon & 111 & $100 \%$ \\
Har haft en annan mobiltelefon innan nuvarande mobiltelefon & 109 & $98 \%$ \\
Universitets-/högskoleutbildning & 94 & $85 \%$ \\
Gymnasieutbildning eller lägre & 17 & $15 \%$ \\
Medelålder & 23 & \\
Medianålder & 23 & \\
Standardavvikelse - ålder & 3 & 2012 \\
Genomsnittligt år för köp av nuvarande mobiltelefon & & \\
\hline
\end{tabular}

Not: Urvalet rensat för avvikande värden.

Källa: Copenhagen Economics.

Vi går i det följande igenom några av de mest intressanta resultaten från enkätundersökningen, som vi senare använder för att utarbeta nudges. Övriga resultat från undersökningen återfinns i Bilaga D.

Först och främst stämde svaren på enkätundersökningens frågor relativt väl överens med svaren från förstudien. Många av de svarande köpte sin nuvarande mobiltelefon på grund av att den förra gick sönder: nästan en tredjedel av respondenterna i enkätundersökningen och $40 \%$ av respondenterna $\mathrm{i}$ förstudien. Hälften av respondenterna $\mathrm{i}$

\footnotetext{
15 Den totala svarsfrekvensen är därmed knappt $30 \%$. En möjlig förklaring till den relativt låga siffran är att enkäten skickades ut under semestertider sommaren 2015. Låg svarsfrekvens gör det svårt att bedöma om de som besvarade enkäten är representativa för hela målgruppen. En fullskalig analys bör eftersträva en högre svarsfrekvens och innehålla en bortfallsanalys.
} 
enkätundersökningen köpte sin nuvarande mobiltelefon för att den förra inte fungerade enligt förväntan, se Figur 9. Dålig funktion av olika orsaker är därmed den enskilt största anledningen till att ungdomarna i studien köper ny mobiltelefon. Bland de som gav det svaret angav omkring hälften att ett tekniskt fel var huvudorsaken till att den förra mobiltelefonens inte fungerade (se Bilaga D). Vidare svarade en fjärdedel att batteritiden var för kort.

Betydligt färre köpte sin nuvarande mobiltelefon utan att ha något egentligt behov av den vid köptillfället. Anledningen var alltså att respondenten ville ha en ny mobiltelefon $(16 \%),{ }^{16}$ att priset på den nuvarande mobiltelefonen var fördelaktigt (11\%) eller att priset på det nya abonnemanget var mer förmånligt jämfört med det tidigare (5 \%).

Figur 9: Varför köpte du din nuvarande mobiltelefon?

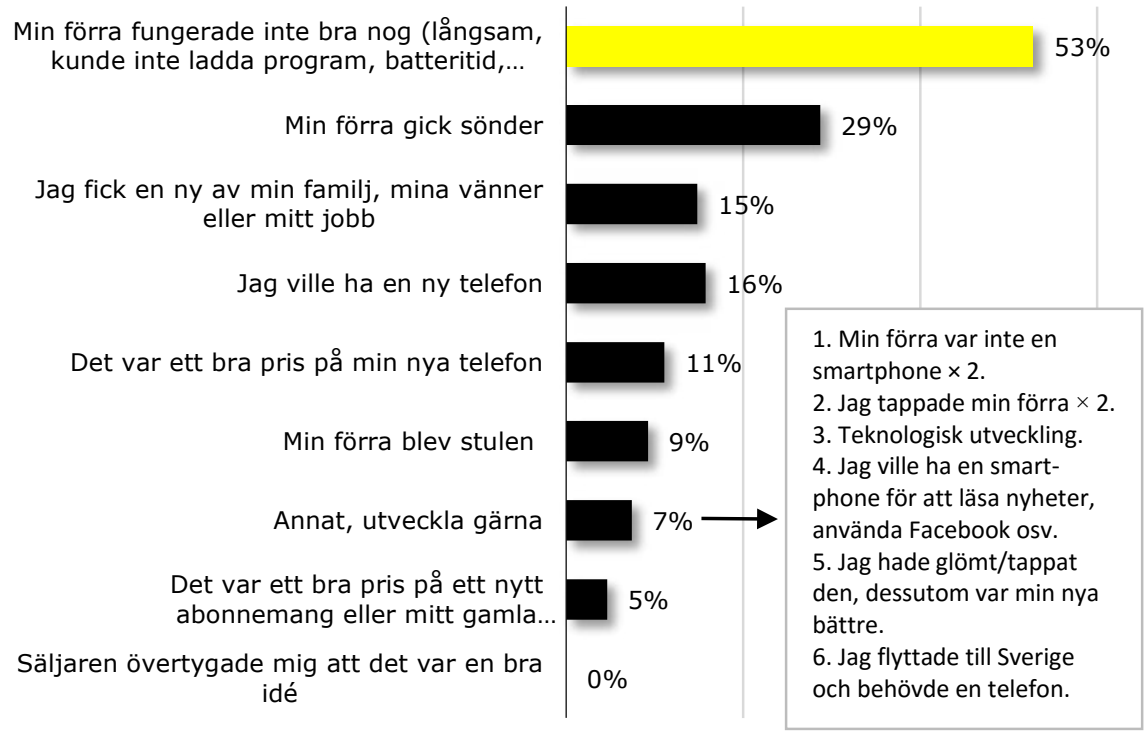

Not: Respondenten kunde ange fler än ett svarsalternativ, vilket gör att totalen inte summerar till 100 \%. I rutan anges de anledningar som de som svarade "annat" angav. $\times 2$ innebär att det var två personer som gav samma anledning.

Källa: Copenhagen Economics.

I många fall är det alltså funktion som driver ungdomars beslut att köpa en ny mobiltelefon, snarare än efterfrågan på en ny modell eller ett bättre pris. Då bör reparation eller uppdatering av den gamla telefonen vara ett

${ }^{16}$ Som tidigare nämnts är urvalsgruppen inte nödvändigtvis representativ för ungdomar i åldern 19 till 28 i de nordiska länderna; de är exempelvis mer högutbildade än populationen i genomsnitt. 
någorlunda likvärdigt alternativ till att köpa en ny. Detta är relevant ur ett hållbarhetsperspektiv, specifikt för att minimera försäljningen av mobiltelefoner. Om ungdomar kan förmås att reparera sin gamla telefon i högre utsträckning i stället för att köpa en ny kan eventuellt nyförsäljningen av mobiltelefoner minskas.

Enkätsvaren visar att majoriteten (54 \%) inte tog reda på om det gick att reparera den gamla, av de respondenter som köpte sin nuvarande telefon på grund av att den förra var sönder eller inte fungerade som den skulle, se Figur 10. Av de som undersökte reparationsmöjligheten försökte över hälften också få den lagad utan framgång. Resterande tyckte att reparation var för dyrt eller för krångligt. Det verkar därmed finnas viss möjlighet att utöka informationen om möjligheterna till reparation, för att minska nyförsäljningen av mobiltelefoner.

Figur 10: Undersökte du om du kunde reparera din gamla telefon innan du köpte en ny?

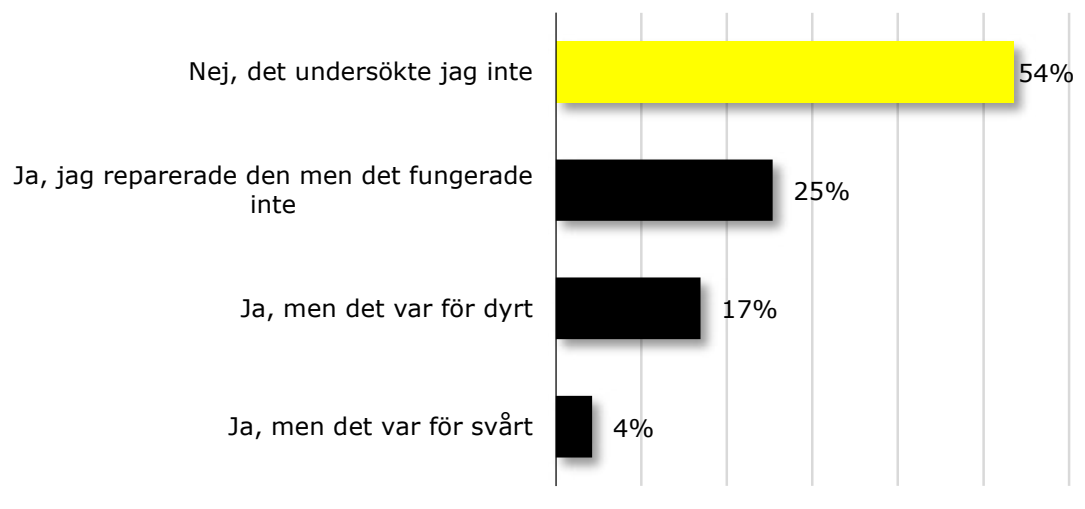

Källa: Copenhagen Economics.

\subsubsection{Miljömedvetenhet vid köp av mobiltelefon}

En del av enkätundersökningen fokuserade på respondenternas miljömedvetenhet vid valet av mobiltelefon. De flesta (44 \%) sade sig inte veta att det finns miljövänliga mobiltelefoner, vilket eventuellt kan förklaras med att detta inte är en utbredd produkt på marknaden i dag. ${ }^{17}$ Dock svarade $14 \%$ att miljön har betydelse vid köp av mobiltelefoner och att de är villiga att betala mer för miljövänliga telefoner, se Figur 11.

17 Vad en miljövänlig telefon innebär definierades inte i frågan. 
Figur 11: Hur viktig är miljön när du köper en mobiltelefon?

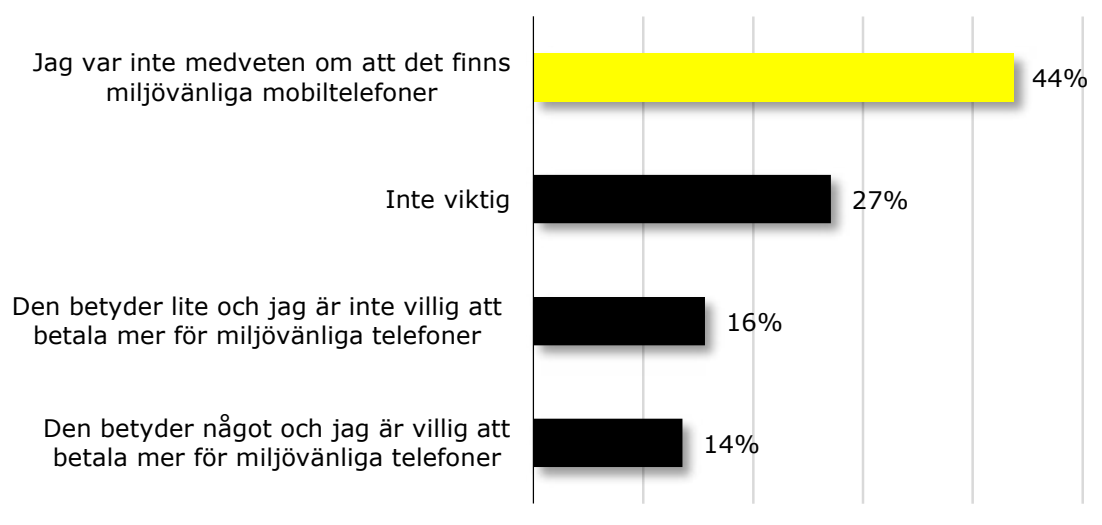

Källa: Copenhagen Economics.

I en liknande fråga undersökte vi hur många som var villiga att köpa en miljövänlig mobiltelefon om den var rabatterad med 200 DKK. På denna fråga svarade $65 \%$ att de kanske eller definitivt kan tänka sig det. Detta är en betydligt större andel än de $14 \%$ som i den tidigare frågan svarade att de anser att miljön har betydelse när de köper mobiltelefoner samt var villiga att betala mer för miljövänliga telefoner. En möjlig förklaring till denna diskrepans kan vara karaktären på de två frågorna. Frågan var "Hur viktig är miljön när du köper en mobiltelefon?", och ett av svarsalternativen var "Den betyder något och jag är villiga att betala mer för miljövänliga telefoner". Det innebär att den svarande ställs inför den implicita frågan om "hur mycket" denne är att betala för att din telefon ska vara miljövänlig om den väljer detta svarsalternativ. I detta fall behöver den svarande själv avgöra vad "betala mer" innebär, samt ta ställning till huruvida man vill göra detta. Den svarande kan därmed föreställa sig att "betala mer" innebär att en miljövänlig telefon är 100 DKK dyrare än andra, men också 200 DKK, 1000 DKK dyrare etc. Den andra frågan löd "Skulle du köpa en miljövänlig mobiltelefon om det var 200 DKK rabatt på miljövänliga mobiltelefoner?", och där finns ett konkret belopp som den svarande kan ta ställning till. Det gör att frågorna inte är helt jämförbara.

Vi ville också undersöka huruvida konsumenter skulle reagera olika på en rabatt på miljövänliga telefoner och en beskattning på vanliga telefoner. Därför skickade vi ut olika frågor till delar av intervjupersonerna. Somliga fick svara på frågan "Skulle du köpa en miljövänlig mobiltelefon om det var 200 DKK rabatt på miljövänliga mobiltelefoner?", och somliga fick frågan "Skulle du köpa en miljövänlig mobiltelefon om icke-miljövänliga mobiltelefoner kostade 200 DKK mer på grund av en miljöskatt?". Eftersom 
urvalet är litet bör resultaten behandlas med försiktighet, men svaren visade sig bli mycket olika beroende på om telefoner beskattas eller rabatteras. Med en miljöskatt på 200 DKK på icke-miljövänliga telefoner skulle 88 \% definitivt eller kanske kunna tänka sig att köpa en miljövänlig telefon, jämfört med $65 \%$ om en miljövänlig mobiltelefon var rabatterad med 200 DKK jämfört med andra telefoner. Detta resultat indikerar att en miljöskatt på icke-miljövänliga telefoner är ett effektivare policyinstrument jämfört med en subvention för miljövänliga telefoner, om målet är att öka försäljningen av miljövänliga mobiltelefoner. Resultaten stämmer också överens med de resultat från beteendeekonomin som funnit att så kallad förlustaversion (motvilja mot att förlora något) gör att individer fäster större värde vid kostnaden av en skatt är vinsten av en rabatt.
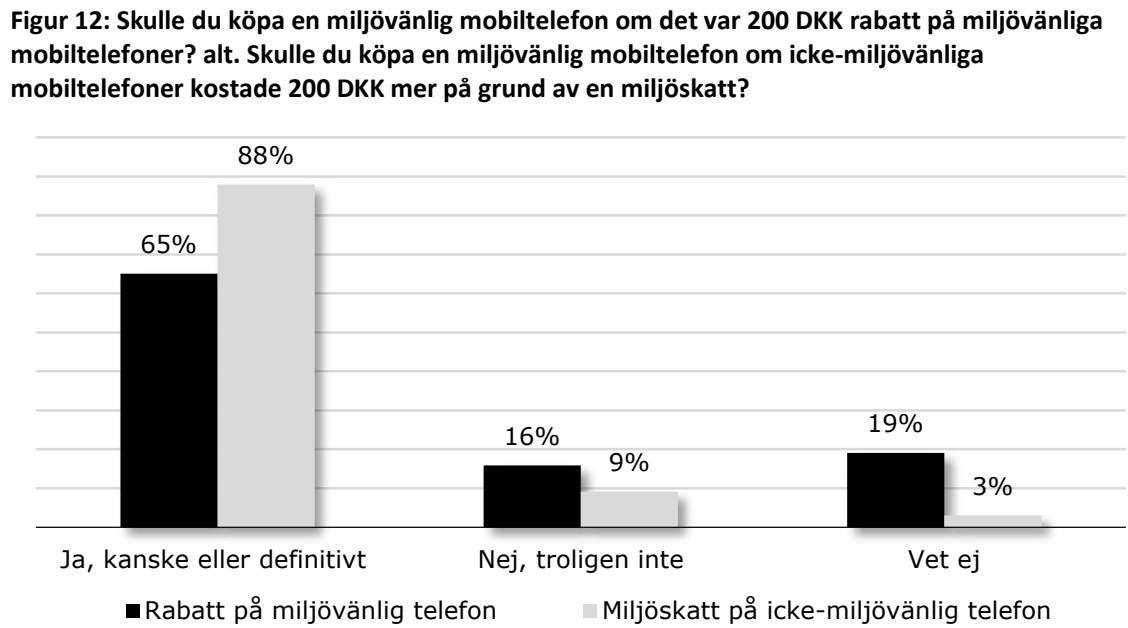

Not: Av de totalt 111 respondenterna fick 72 svara på den första frågan: "Skulle du köpa en miljövänlig mobiltelefon om det var 200 DKK rabatt på miljövänliga mobiltelefoner?" Resterande 39 personer fick frågan: "Skulle du köpa en miljövänlig mobiltelefon om icke-miljövänliga mobiltelefoner kostade 200 DKK mer på grund av en miljöskatt?"

Källa: Copenhagen Economics.

En fråga i enkätundersökningen gällde användning av sekundära mobiler, det vill säga mobiler utöver den man exempelvis använder dagligen. $\mathrm{Vi}$ undersöker här anledningen till att respondenterna behåller gamla telefoner i stället för att sälja eller lämna dem till återvinning. Majoriteten (40 \%) av respondenterna har en extra telefon för att det är bra att ha ifall den nuvarande går sönder, se Figur 13. Detta kan ses som ett rationellt val, och nudging har inte någon roll att spela här. De två efterföljande svarskategorierna är dock eventuellt relevanta för nudging: $15 \%$ sade sig 
inte veta vad de ska göra med denna extra telefon, och $14 \%$ sade sig inte ha tänkt över vad de ska göra med den.18

Figur 13: Tänk på en mobiltelefon som du äger, som inte är den du använder nu. Vilken är anledningen till att du fortfarande äger den?

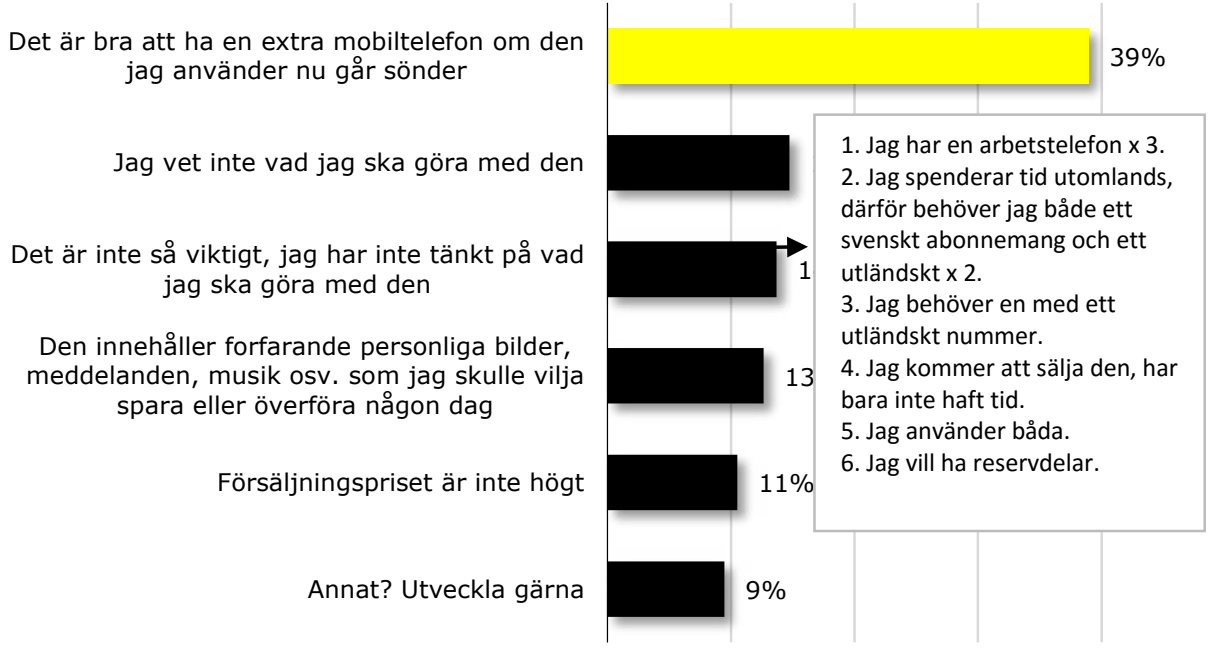

Not: Respondenten kunde ange flera svar. I rutan anges de anledningar som de som svarade "annat" angav. $\times 3$ och $\times 2$ innebär att det var tre respektive två personer som gav samma anledning.

Källa:

Copenhagen Economics

För att öka insamlingen av mobiltelefoner så att de kan återanvändas eller återvinnas är en möjlig åtgärd att införa ett pantsystem, där personer som köper en mobiltelefon betalar en pant som de får tillbaka när de återlämnar mobilen, antingen till återförsäljaren eller till en annan avsedd plats. Undersökningen omfattade frågan vad den panten minst behöver vara för att respondenten ska tycka det är värt att återlämna telefonen och få pengarna tillbaka. För de flesta av respondenterna skulle 500 DKK vara den lägsta summan, se Figur 14. Totalt skulle mer än $50 \%$ se det som värt att lämna tillbaka en gammal telefon om panten var mellan 50 och 300 DKK.

\footnotetext{
${ }^{18} \mathrm{Ett}$ problem med att samla in gammal elektronik för exempelvis återanvändning är att insamling inte nödvändigtvis ger ett mer miljövänligt resultat än om konsumenter låter produkterna ligga kvar hemma. I fallet mobiltelefoner riskerar dessa att hamna på andrahandsmarknader i länder som har dåliga system för insamling och återvinning. Frågan är därmed huruvida insatser som samlar in gamla telefoner ska premieras. Vi undersöker inte detta närmare, men lägger i experimenten mindre fokus på nudging för att öka återvinning av mobiltelefoner, än för att minska nyköp och öka återanvändningen.
} 
Figur 14: Hur mycket skulle du som ett minimum lägga i pant vid köptillfället, för att vara villig att lämna tillbaka telefonen mot pant efter användning (i stället för att t.ex. behålla mobiltelefonen eller sälja den)? Alternativen anges i DKK.

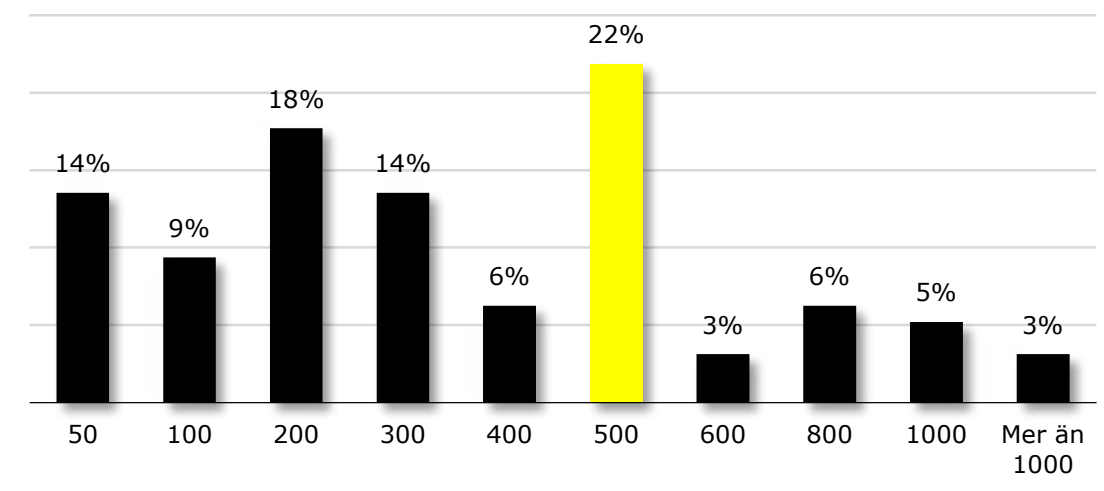

Källa: Copenhagen Economics.

\subsubsection{Innehav av mobiltelefon - äga eller hyra?}

En del av enkätundersökningen gick ut på att undersöka huruvida ungdomarna kan tänka sig att hyra en mobiltelefon i stället för att äga den. ${ }^{19}$ Uthyrning från företag, det vill säga affärsmodeller där telefoner hyrs ut om och om igen, kan tänkas styra produktionen mot längre livslängd på mobiltelefoner i stället för att de som i dag blir oanvändbara relativt snabbt. ${ }^{20}$

Resultaten visar att ungdomarna i undersökningen värdesätter själva ägandeskapet: majoriteten (60\%) tycker det är antingen mycket viktigt eller viktigt att äga sin mobiltelefon. För $41 \%$ är det inte viktigt eller spelar ingen roll. Det innebär dock att relativt många är öppna för alternativ till traditionella ägarmodeller, se Figur 15. Detta är speciellt anmärkningsvärt då leasingmarknaden är relativt outvecklad - ungdomar behöver alltså ta ställning till något som i princip ännu inte finns att välja. 
Figur 15: Hur viktigt är det för dig att äga mobiltelefonen i stället för att hyra den?

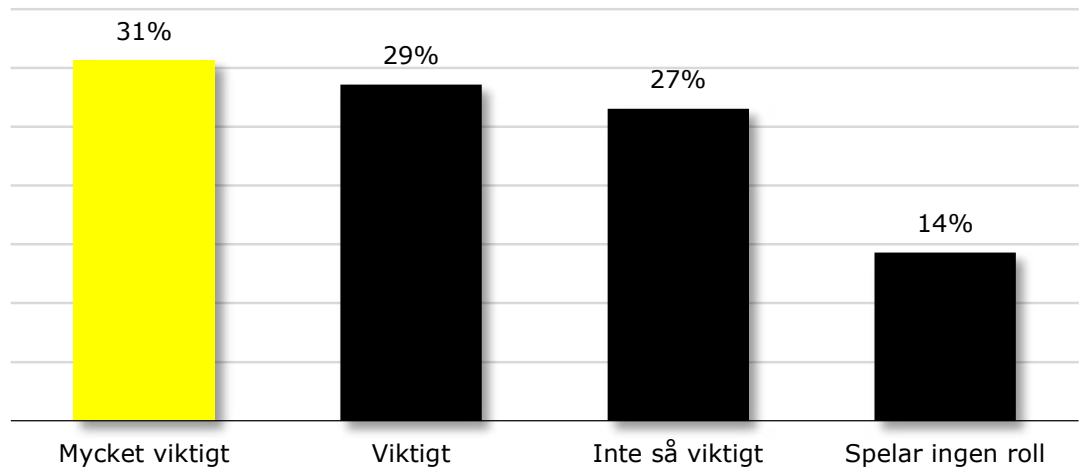

Not: Siffrorna summerar inte till 100 på grund av avrundning.

Källa: Copenhagen Economics.

\subsection{Sammanfattande slutsatser från beteendekartläggningen}

Huvudsyftet med beteendekartläggningen är att undersöka om det finns identifierbara, oavsiktliga beteenden eller beteendehinder som hämmar en hållbar konsumtion av mobiltelefoner bland ungdomar. Slutsatsen är att det finns många tecken på att så är fallet. Särskilt intressant är det att relativt många ungdomar köper en ny telefon som konsekvens av att den gamla är trasig, utan att först undersöka möjligheten till reparation. Ett sådant beteende kan återspegla att ungdomar inte är intresserade av reparationer - det vill säga, de agerar rationellt när de köper en ny mobiltelefon för att den gamla gått sönder. Det kan också återspegla att ungdomar inte är tillräckligt medvetna och informerade om reparationsmöjligheterna eller möjligheterna att köpa en begagnad mobiltelefon. Om det senare är fallet finns det potential att testa en nudge som gör dem medvetna om dessa möjligheter vid rätt tillfälle.

Ett ytterligare intressant resultat är att det verkar finnas en viss miljömedvetenhet och betalningsvilja för gröna telefoner samt intresse för leasing. Detta är intressant eftersom marknaden är outvecklad för båda dessa alternativ - ungdomar behöver alltså ta ställning till något som i princip ännu inte finns att välja. Här finns också eventuellt utrymme för nudging, i syfte att öka möjligheten för ungdomar att agera i linje med sina preferenser. 


\subsection{Två experiment}

Baserat på resultaten $\mathrm{i}$ beteendekartläggningen utarbetar vi två experiment som testar olika nudges. I det första, mest omfattande experimentet, undersöker vi om vi kan öka andelen som väljer att antingen laga sin trasiga mobil eller köpa en begagnad mobil som ett alternativ till en ny, genom att aktivt erbjuda dessa två alternativ i butiken. Detta är det primära beteendehypotes vi vill testa i nudgingexperimenten eftersom vi bedömer att detta område har störst potential när det gäller att åstadkomma en hållbar beteendeförändring. Pilotstudiens begränsade omfattning gör det också nödvändigt att fokusera experimentet till de områden vi bedömer ha störst potential. Vi gör dock ett litet ytterligare experiment där vi testar möjligheten att genom nudging öka leasing och köp av "gröna" telefoner.

\subsection{Nudging för ökad reparation och köp av begagnade telefoner}

I det första, mest omfattande experimentet undersöker vi om vi kan öka andelen som väljer att laga sin trasiga mobil eller köpa en begagnad mobil som ett alternativ till en helt ny. Detta sker genom att aktivt erbjuda dessa två alternativ i butiken. Hypotesen är att många ungdomar inte väljer eller inte överväger - reparationer eller begagnade mobiler som ett alternativ på grund av bristande information, låg medvetenhet och hög komplexitet. Detta kan illustreras enligt följande:

Anta att en ung person vars mobiltelefon gått sönder står i sin lokala telefonbutik för att hitta en lösning på problemet; exempelvis har skärmen spruckit. ${ }^{21}$ Här ges ungdomen möjlighet att ersätta sin skadade mobil med en ny, medan möjligheter att byta ut skärmen (eller att köpa en begagnad mobiltelefon) inte erbjuds. I den här situationen utsätts ungdomar för en mängd inflytanden som alla leder i riktningen mot inköp av en ny mobil, se Tabell 13. Resultatet är att många till slut lämnar butiken med en ny mobiltelefon.

\footnotetext{
${ }^{21}$ Vi vet från intervjuerna att en ungdom vars mobil gått sönder typiskt söker upp en telefonåterförsäljare ofta samma affär som denne en gång köpte telefonen i.
} 
Tabell 3: Relevanta beteenden när mobilen skadas

Köp ny mobil

Tillgänglighetsskevhet (availability

bias), rutiner och vanor

Psykologisk diskontering

Sociala normer

Förtroende

Jånenten har många alternativ, både bland ny telefoner och mellan nytt/reparation/begagnat, varav somliga är bättre än andra. Det gör lätt att man som konsument väljer ett alternativ som är "tillräckligt bra" utan att värdera alla alternativ för att hitta det som är bäst.

Förlustaversion Konsumenten vet vad denne får vid köp av en n mobil. Detär ett får hjälp på plats. vid själva köpet. En Iphone 6 med abonnemang kost ca $330 \mathrm{kr}$ i mand som biligt pga. psykologisk diskontering ("if framtiden ("snart får jag ett jobb") få köpa en nyare modell. Den fysiska miljön i
Konsekvens

Konsumenten känner inte till en bra reparatör, eller känner sig inte trygg med att anlita reparatörer.

En ny mobil kan med avbetalning kosta så lite som 0 kr

Det kostar ca $1000 \mathrm{kr}$ att reparera skärmen. För Donsumenten är det pengar direkt ur fickan och det ar ekonomiskt kännbart i stunden (psykologisk diskontering). Utgiften läggs ovanpå tidigare utgifter på mobilen (inte sunk cost).

En trasig mobil är en möjlighet/ursäkt för kunden att Inget tyder på att det är trendigt bland ung manniskor att välja reparation framför nyköp. Butiken riktningen.

Konsumenten litar inte på reparatörer. Det är en "black box" att få sin mobil reparerad. Det finns få välrenommerade, Apple-auktoriserade reparä̈rer.

Det kan vara svårt för konsumenten att överväga och utvärdera alla olika handlingsalternativ när mobilen går sönder, dvs. konsumenten vet inte säkert vilket alternativ som är bäst, men har troligen en .

Konsumenten vet inte hur mycket en reparation kostar. Konsumenten vet inte heller om reparatione kommer lyckas och om kostnaden täcks av en garant
Konsumenten kan inte få sin mobil reparerad i butiken, och överväger därför inte reparation som en möjlig lösning.

Man jämför inte $5500 \mathrm{kr}$ (totalkostnad för ny mobil) med $1000 \mathrm{kr}$ (reparationskostnad), utan stället med $330 \mathrm{kr}$ (månadskostnad för ny mobil). Den faktiska kostnaden för de respektive alternativens återstående levnadstid jämförs därmed inte - endast det pris man betalar vid köptillfället.

Att köpa en ny mobil uppfattas som det riktiga/normala valet.

Konsumenten känner sig mest trygg med att köpa en ny mobil.

Det är möjligt att det "bästa" alternativet är reparation, men att informationsbrist, komplexite och riskaversion gör att konsumenten uppfattar "nköp som"tilläckligt bra".

Konsumenten värderar reparationen att vara för riskfylld, och söker den bekvämaste lösningen.

Källa: Copenhagen Economics. 
För att testa hypotesen är den relevanta frågan huruvida fler ungdomar skulle ha valt att reparera sin mobiltelefon eller köpa en begagnad telefon om de erbjudits dessa möjligheter i telefonaffären. Ett aktivt erbjudande om antingen reparation eller begagnade mobiler skulle överbrygga samtliga tre beteendehinder: det tillhandahåller direkt information (t.ex. om priset på reparation), ökar medvetenheten (man får upp ögonen för idén) och minskar komplexiteten (den är lätt och säkert i affären). Hypotesen testas genom att jämföra svaren från tre olika versioner av en frågeenkät som $\mathrm{i}$ en slumpartad fördelning besvaras av respondenter (se Bilag E, Bilag F och Bilage G för de tre versionerna). I den första versionen får konsumenten erbjudande om att köpa en ny mobil men också att reparera skärmen på den gamla mobiltelefonen. I den andra versionen får konsumenten erbjudande om att köpa en ny eller en begagnad mobiltelefon. I den tredje versionen erbjuder en expedit konsumenten enbart att köpa en ny mobil. De första två versionerna innehåller alltså nudges, medan den tredje är referensscenariot vilket återspeglar den nuvarande situationen. Det är viktigt att betona att respondenterna i alla tre versioner kan välja samma möjligheter; det krävs endast att svarspersonen söker upp dem själv genom att bläddra bland erbjudandena på efterföljande sidor. Den enda skillnaden mellan de tre olika versionerna är alltså vad som aktivt erbjuds i butiken. Det går att isolera effekten av det aktiva erbjudandet genom att på ett slumpartat vis aktivt erbjuda några deltagare att reparera skärmen eller köpa en begagnad mobiltelefon (behandlingsgruppen), medan andra inte aktivt får erbjudandet utan själva är tvungna att undersöka möjligheten (kontrollgruppen). Detta kallas ett randomiserat, kontrollerat experiment, och metoden och urvalet för studien beskrivs i Box 6 .

Box 6. Metod nudgingexperiment - kort om kontrollerade experiment

Vi har genomfört randomiserade kontrollerade experiment (RCT eller Randomized Control Trials på engelska) som undersöker möjligheten att med hjälp av nudges öka hållbar konsumtion av mobiltelefoner bland ungdomar. Kontrollerade experiment används för att testa kausala samband mellan två faktorer. Metoden består i att slumpmässigt dela upp ett tillräckligt stort stickprov i två undergrupper: en försöksgrupp och en kontrollgrupp. Målet är att de två grupperna inte ska skilja sig åt systematiskt.

Personerna i försöksgruppen får en "behandling", t.ex. en medicin, och kontrollgruppen får antingen ingenting eller en placebobehandling. Vid en given tidpunkt jämförs utfallsvariabeln, som t.ex. kan vara något slags mått på 
friskhet, för de två grupperna. En eventuell skillnad kan antas vara ett resultat av behandlingen eftersom grupperna i genomsnitt är identiska. Effekten kallas därför "behandlingseffekten".

Metoden är unik i sin förmåga att på ett tillförlitligt sätt isolera kausala effekter och är därför dominerande inom medicinsk forskning. Under de senaste decennierna har användningen av kontrollerade experiment också ökat inom ekonomisk forskning, och då främst inom beteende- och utvecklingsekonomi.

I bästa fall hade experimenten utförts i telefonbutiker såsom Telia, Telenor eller 3. Då hade personer med skadade mobiler varannan gång aktivt erbjudits att reparera skärmen eller att köpa en begagnad mobiltelefon, utöver alternativet att köpa en ny mobiltelefon. Det har emellertid inte varit möjligt att utföra sådana experiment i praktiken. I stället har vi försökt att återskapa samma situation i ett frågeformulär, som vi har bett gymnasie- och universitetsstuderande att svara på. Sammanlagt har 181 elever från Frederiksbergs gymnasium, Gefion gymnasium och Köpenhamns universitet $\mathrm{i}$ Danmark besvarat frågeformuläret. En nackdel med urvalet är att vi inte lyckas fånga gruppen ungdomar över 19 år som inte studerar. I en fullskalig studie bör även representanter från denna grupp inkluderas.

Den främsta nackdelen med enkätundersökningar är att man inte kan vara säker på att enkätsvaren återspeglar det verkliga beteendet. Denna nackdel reduceras emellertid väsentligt när enkätundersökningen utformas som ett randomiserat, kontrollerat experiment med kontroll- och behandlingsgrupp. I ett sådant experiment är inte de absoluta nivåerna på de insamlade svaren viktigast (t.ex. hur många som väljer att reparera sin telefon) utan skillnaden i nivåerna mellan behandlings- och kontrollgruppen (t.ex. om den nudgade behandlingsgruppen oftare väljer att repararea sin telefon). Eventuella snedvridningar i enkätundersökningen neutraliseras av att snedvridningen troligtvis är densamma i både behandlings- och kontrollgruppen.

Källa: Copenhagen Economics.

Det finns två möjliga resultat av detta experiment. För det första kan ungdomar välja att reparera sina mobiler, köpa begagnade mobiler och att köpa nya telefoner i samma utsträckning som tidigare. Om så är fallet betyder det att ungdomars nuvarande efterfrågan på mobiltelefoner återspeglar deras preferenser, och att det inte finns potential för nudging. Som tidigare beskrivits har nudging bara en roll att spela om det finns barriärer som gör att individer inte agerar i linje med sina faktiska preferenser. 
För det andra kan ungdomar i experimentet i större utsträckning välja att reparera sin mobiltelefon eller köpa en begagnad telefon när detta aktivt erbjuds i butiken. Det utfallet betyder att det finns en faktisk beteendebarriär som förhindrar individen att göra ett optimalt val för mobiltelefoner, och att nudging kan spela en avgörande roll för att skapa ett mer ändamålsenligt beteende för både ungdomarna själva och samhället som helhet.

\subsubsection{Resultat: nudging kan potentiellt ha stor effekt}

Resultaten från det första experimentet visar att nudging kan ha en betydande effekt för att uppnå en mer hållbar användning av mobiltelefoner bland ungdomar. Figur 16 visar hur stor andel av respondenterna som väljer att reparera skärmen på sin telefon om de 1) får skärmreparation framhållet i affären, 2) enbart får erbjudande om att köpa en ny telefon i butiken.

Experimentet visar att nästan $87 \%$ väljer att reparera skärmen om detta alternativ aktivt framhålls i telefonaffären, jämfört med $67 \%$ om butikspersonalen framhåller begagnade eller nya tele. Detta motsvarar 20 procentenheter fler än i referensscenariot, det vill säga den nuvarande situationen. En signifikant andel av respondenterna svarar därmed positivt på nudgen.

Figur 16: Effekt av nudge för skärmreparation

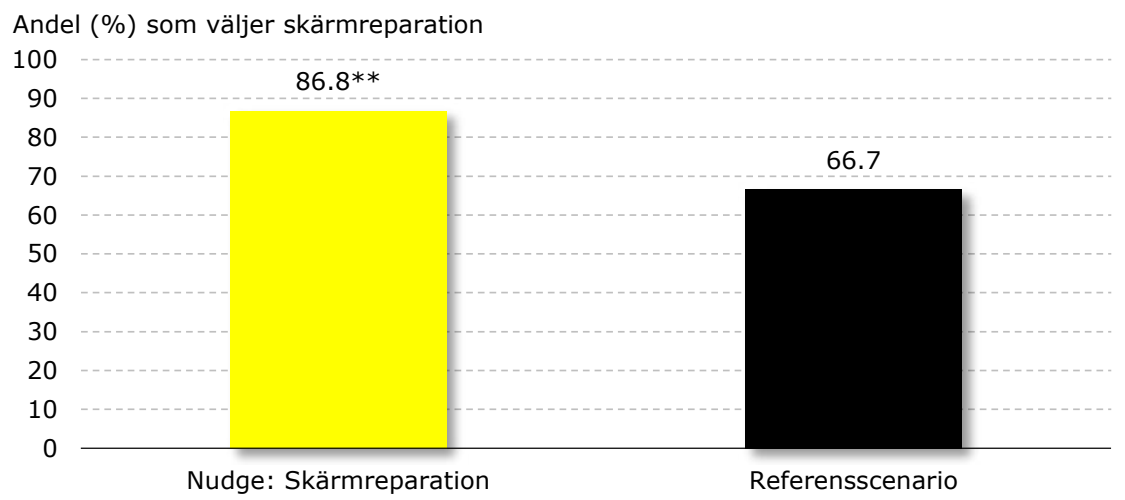

Not: ${ }^{* *}$ ) Resultaten för nudge: Skärmreparation skiljer sig från de andra två kategorierna på en 5procentig signifikansnivå med ett tvåsidigt t test.

Källa: Copenhagen Economics.

Figuren ovan visar också att relativt många väljer att reparera skärmen när deras mobil går sönder. Det är intressant i sig, men det avspeglar till viss grad att det i experimentet var ganska lätt att hitta priser och 
alternativ för reparation (man behövde bara bläddra i formuläret). Det är därför möjligt att orealistiskt många valde att "lämna butiken" och undersöka andra alternativ jämfört med vad som vore fallet i verkligheten. Resultatsiffrorna är också högre än de faktiska siffor som uppmättes i beteendekartläggningen, där $46 \%$ sade sig ha undersökt möjligheten att reparera sin mobiltelefon innan de köpte en ny - jämfört med $66,7 \%$ i Figur 16. Denna skillnad tyder dock också på att det finns hinder för att ungdomar ska kunna välja det beteende som ligger i linje med deras preferenser - fler skulle välja att få sin telefon lagad om det var lättare. Att sänka hindren för reparation, genom nudging eller på andra sätt, är därmed potentiellt en viktig möjlighet för att öka hållbar konsumtion bland ungdomar.

Även när det gäller begagnade mobiler finner vi att nudging kan spela en viktig roll. I undersökningen väljer $28,9 \%$ att köpa en begagnad mobil när det erbjuds aktivt $\mathrm{i}$ butiken, vilket är sju gånger fler än $\mathrm{i}$ referensscenariot, se Figur 17. Mycket få väljer en begagnad telefon om bara nya telefoner framhålls (4 \%). Detta indikerar att fler ungdomar skulle köpa begagnade mobiler om de erbjöds i butiken och därmed fanns med synliga priser.

\section{Figur 17: Effekt av nudge för begagnade mobiltelefoner}

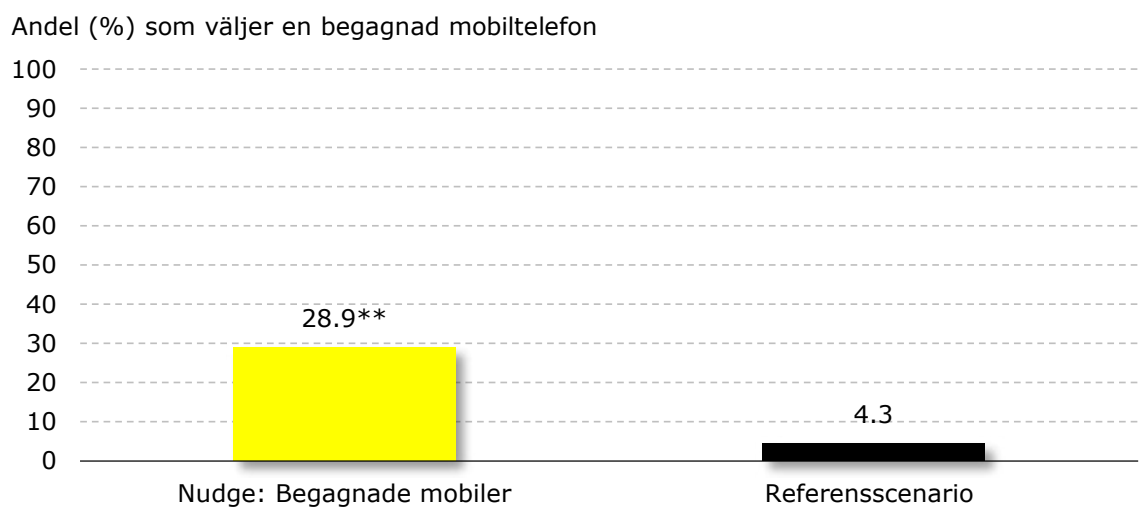

Not: $\left.{ }^{* *}\right)$ Resultaten för nudge: Begagnade mobiler skiljer sig från de andra två kategorierna på en 5procentig signifikansnivå med ett tvåsidigt $\mathrm{t}$ test.

Källa: Copenhagen Economics.

På motsvarande sätt väljer betydligt fler respondenter att köpa en ny mobil om det bara är nya mobiler som framhålls i butiken. Referensscenariot speglar den nuvarande situationen på mobiltelefonmarknaden, och då väljer $29 \%$ att ersätta en förstörd mobil med en ny. Det är nästan tre gånger så många som när antingen reparation eller begagnade mobiler nudgas (framhålls i affären), se Figur 
18. I experimentet där begagnade mobiler nudgas skulle $11 \%$ köpa en ny telefon, och i versionen där skärmreparation nudgas är andelen också nästan $11 \%$. Även här finns alltså tydliga tecken på att brist på information, låg medvetenhet och hög komplexitet faktiskt skapar en oönskad inköpskultur bland ungdomar.

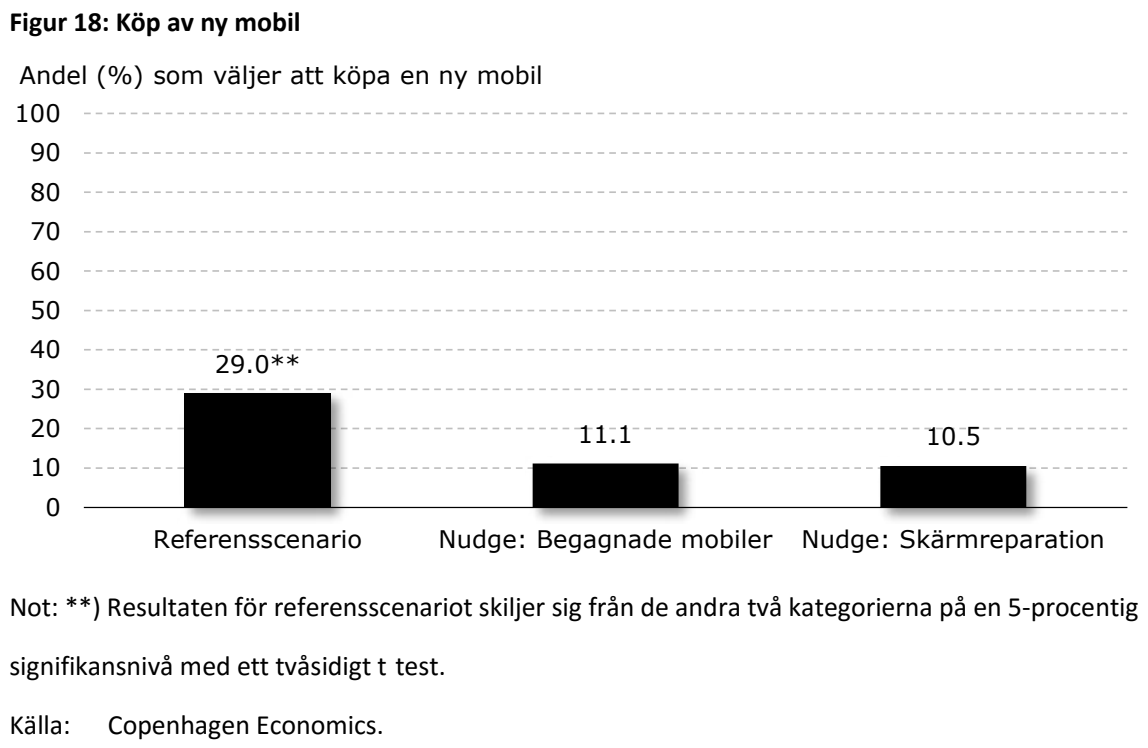

\subsection{Decoy-effekten för ökad leasing och köp av "gröna" telefoner}

I det andra försöket undersökte vi om vi kan öka andelen ungdomar som väljer att hyra sin mobil som ett alternativ till att köpa. Vi konstruerade två versioner av ett frågeformulär (se bilaga $\mathrm{D}$ och $\mathrm{E}$ ). I den första versionen bad vi ungdomar välja antingen en mobil som de äger eller hyr. I den andra versionen introducerade vi en så kallad decoy (ungefär ett lockbete på svenska). Utgångspunkten för decoy-effekten är att det kan vara svårt att välja mellan två alternativ där inget objektivt sett är bättre än det andra. Valet blir lättare om det införs ett tredje alternativ som objektivt sett är sämre än ett av de två första. Man kan exempelvis introducera en telefon som kan hyras, men till villkor som är mindre förmånliga än för den första hyrtelefonen. Då ökar sannolikheten för att konsumenterna väljer 
hyrtelefonen med bättre villkor eftersom de nudgas mot detta alternativ. Decoy-effekten har påvisats för ett antal produkter. ${ }^{22}$

Exakt motsvarande versioner utformas och testas för en "grön" mobil (se bilaga F och G). Den gröna mobilen presenteras som en "miljövänlig mobil", och en särskild faktaruta påpekar att alla metaller och komponenter i telefonen är inköpta efter vissa krav på hållbarhet.

Återigen finns det två möjliga resultat av detta experiment: decoyeffekten kan antingen fungera eller inte träda in. Resultaten från det första experimentet kan potentiellt få stora konsekvenser för hållbar konsumtion av mobiltelefoner medan det andra försöket får mer blygsamma resultat.

Här undersöks endast effekten av en enskild nudge. Det är dock ändå intressant att se om ungdomar kan påverkas i en grön riktning när det gäller mobiltelefoner.

\subsubsection{Resultat: Decoy har effekt på leasing men inte gröna telefoner}

I det andra experimentet finner vi att decoy-effekten påverkar andelen som vill hyra sin mobiltelefon jämfört med att äga den. Tillägg av ett $\mathrm{i}$ princip irrelevant alternativ gör att $62 \%$ väljer att hyra sin telefon jämfört med $38 \%$ utan nudging, se Figur 19. I figuren är det primärt skillnaden mellan nivån på de två kolumnerna som är intressant. I experimentet var det svårt att konstruera lättbegripliga alternativ för de svarande att ta ställning till, så priset på en hyrtelefon sattes till en schablonsumma på 200 DKK per månad. Priset för att i stället köpa en telefon sattes till det faktiska kontantpriset, och alltså inte den månadskostnad man betalar med abonnemang. Konsumenterna ställdes alltså i referensscenariot mellan valen att betala 200 DKK i månaden eller 5300 DKK i "affären", vilket i sig är ett val som kan påverkas av olika faktorer. Det som spelar roll är att en signifikant större andel sade sig vara villiga att hyra en telefon när ett tredje alternativ introducerades: en hyrtelefon som i stället för 200 kostar 300 DKK i månaden.

\footnotetext{
${ }^{22}$ Exempelvis har en decoy-effekt identifierats för olika prenumerationsalternativ av tidningen "The Economist", och effekten har använts för att förklara hur konsumenter väljer restauranger, se exempelvis http://www.e-reading.club/bookreader.php/138702/Ariely_-

_Predictably_Irrational_The_Hidden_Forces_That_Shape_Our_Decisions.pdf och http://www.washingtonpost.com/wp-dyn/content/ article/2007/04/01/AR2007040100973.html.
} 
Figur 19: Effekt av nudge för uthyrning av mobil

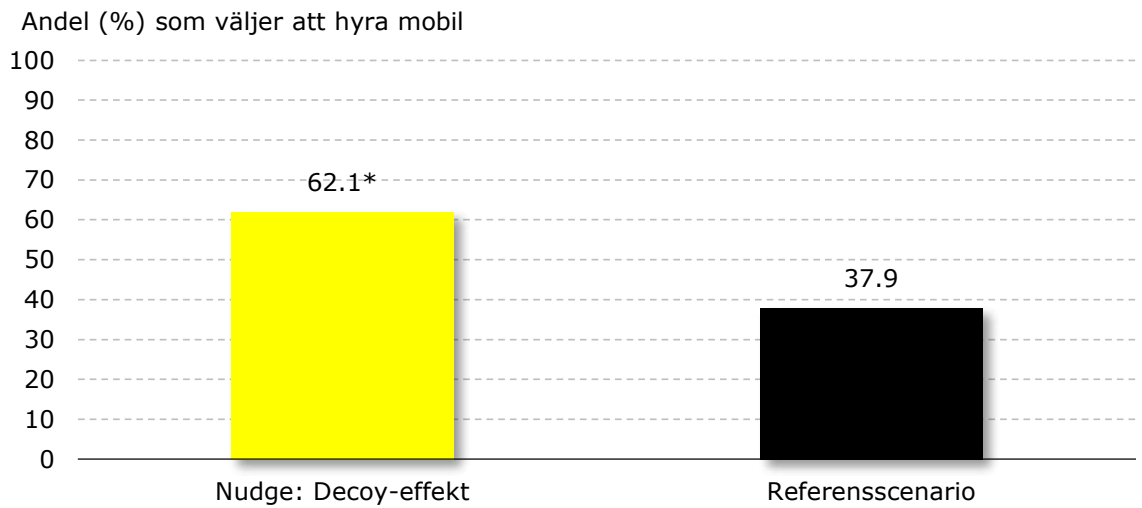

Not: *) Resultaten för nudge: Decoy-effekten skiljer sig från de andra två kategorierna på en 10 procentig signifikansnivå med ett tvåsidigt T-test. Med ett ensidigt T-test är skillnaden signifikant på en 5 procentig nivå.

Källa: Copenhagen Economics.

Decoy-effekten visade sig inte direkt påverka valet mellan att köpa en "grön" mobil och ett konventionellt alternativ, se Figur 20. Vi finner heller ingen statistiskt signifikant effekt utan skillnaden mellan de två staplarna är så små att de bör betraktas som lika stora. Det finns flera möjliga förklaringar till detta. För det första behöver en prisrabatt inte påverka de mekanismer som gör att man väljer en grön telefon; motiven att välja en grön telefon är antagligen inte ekonomiska utan grundas i viljan att agera miljövänligt. För det andra finns en möjlighet att ekonomiska incitament kan verka i motsatt riktning genom att rabattera en produkt man redan frivilligt väljer att betala mer för - en så kallad utträngningseffekt. ${ }^{23}$ Att välja en grön mobil bekräftar en självbild som miljömedveten, och genom att sänka priset på denna förflyttar man medvetenheten till just priset. Konsumenten tänker då alltså mer på priset än på det faktum att man gör något bra för miljön, och avstår från den miljövänliga varan eftersom denna är dyrare. 
Figur 20: Effekt av nudge för "gröna mobiler"

Andel (\%) som väljer att "köpa grönt"

100

90

80

70

60

50

40

30

20

10

0

47.7

52.3

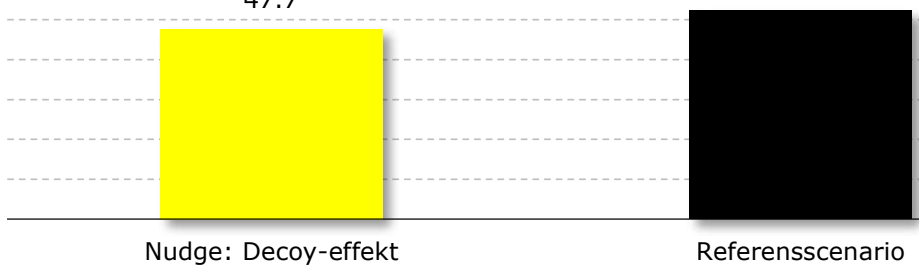

Nudge: Decoy-effekt

Referensscenario

Not: Resultaten för nudge: Decoy-effekten skiljer sig inte från de andra kategorierna på en 5- eller 10-procentig signifikansnivå.

Källa: Copenhagen Economics. 


\section{Slutsatser och policyimplikationer}

Traditionella styrmedel för hållbar konsumtion är främst utformade för teoretiskt rationella konsumenter, vilket inte alltid ger optimala resultat eftersom det mänskliga beteendet ofta avviker från antaganden i förenklade ekonomiska modeller. Faktorer såsom oföretagsamhet, mentala genvägar och vanor kan göra att konsumenter inte alltid väljer det alternativ som är bäst i objektiv mening och enligt deras egna preferenser. Exempelvis har det visat sig att konsumenter i begränsad utsträckning investerar i privatekonomiskt lönsamma energisparande åtgärder, främst på grund av att det innebär en hög initial kostnad som först betalar av sig på sikt. Den beteendeekonomiska förklaringen är så kallad psykologisk diskontering: man värderar utgifter som sker i dag (kostnaden för de energieffektiviserande åtgärderna) högre än vinster längre fram i tiden (månatliga besparingar på elräkningen).

Dessa insikter är inte nya: Redan i början av femtio- och sextiotalet ifrågasatte ekonomer, kognitiva psykologer och socialpsykologer antagandet om rationella konsumenter i klassiska ekonomiska modeller. Det är dock först på senare år resultaten från denna forskning har börjat översättas i politik och praktiska åtgärder. Genom att förstå och ta hänsyn till konsumenters faktiska beteenden kan beslutsfattare utforma politik för att nå uppsatta mål på ett kostnadseffektivt sätt.

De beteenden som leder till oönskade utfall kan motarbetas med olika nudges - det vill säga förändringar i den valsituation som konsumenter står inför. Syftet med detta är att förändra deras beteende på ett förutsägbart sätt utan att begränsa antalet alternativ eller avsevärt förändra grundläggande ekonomiska incitament. Det kan exempelvis handla om att påminna miljömedvetna människor om dessa värderingar med märkningssystem, eller att skapa förutsättningar för ökad koncentration och eftertänksamhet inför ett annars rutinmässigt val.

Den här rapporten undersöker hur nudging har använts och kan användas för att öka hållbar konsumtion av elektronikprodukter. Med hållbar konsumtion menas här att köpa färre elektronikprodukter, köpa mer miljövänliga eller långlivade elektronikprodukter, använda produkter man äger längre, återanvända elektronikprodukter i större utsträckning 
och återvinna uttjänta produkter. Resultaten visar att det finns en teoretisk potential att använda nudging för just detta, främst vid köp av ny elektronik men också för att få individer att använda produkter längre (genom att exempelvis öka reparationer) och vid beslut om återvinning.

Beskrivningen här är översiktlig eftersom de beteenden och därmed styrmedel som kan påverka skiljer sig signifikant åt mellan olika typer av köp inom elektronik (småel, vitvaror etc.), olika situationer vad gäller konsumtion av elektronik (köp, beslut om återanvändning, återvinning) och olika demografiska grupper (unga gentemot äldre etc.). Syftet har inte heller varit att fullt ut belysa alla dessa olika dimensioner, utan att presentera ett ramverk för hur beteendevetenskap kan användas för att förstå människors konsumtionsbeslut och illustrera hur nudges kan användas för att försiktigt styra i en mer hållbar riktning.

I ett pilotexperiment går vi djupare in på en specifik kategori: konsumtion av mobiltelefoner i åldersgruppen 19 till 28 år. Följande stycke sammanfattar våra huvudsakliga observationer och policyrekommendationer baserat på tidigare studier och rapporter samt intervjuer med aktörer som skulle kunna tillämpa nudging. Därefter sammanfattas resultaten av vår pilotstudie av konsumtionsbeteenden på mobiltelefonmarknaden, och implikationerna av resultaten beskrivs. Slutligen ges förslag på vidare forskning.

\section{1 Övergripande observationer och generella rekommendationer kring nudging för hållbar konsumtion}

\subsubsection{Nudging som del av ett större styrmedelspaket}

Nudging och andra typer av styrmedel behöver inte utesluta varandra tvärtom. Nudging handlar enligt de mest använda definitionerna (t.ex. Thaler \& Sunstein, 200) om att förändra människors beteende, vilket förutsätter att de redan har de attityder som krävs för att uppvisa detta beteende. Exempelvis förutsätter miljömärkning att konsumenter är intresserade av att konsumera miljövänligt och är villiga att betala mer för miljövänliga produkter. Miljömärkningen ska endast påminna konsumenterna vid köptillfället om dessa värderingar. Detta innebär att nudging utan underliggande attityder inte är verkningsfullt - att bli påmind om miljövärderingar hjälper inte om man inte delar dessa värderingar. ${ }^{24}$

${ }^{24}$ I andra fall är det inte lika tydligt att nudging hjälper individer att välja enligt de egna attityderna och preferenserna, utan att ändra på dessa. I de fall man använder nudging för att minska matkonsumtion genom 
Övriga styrmedel såsom information syftar just till att påverka attityderna. Nudging kan här spela en roll för att framställa attitydpåverkande information på ett tilltalande sätt, eller för att understryka ekonomiska skillnader mellan hållbara och mindre hållbara alternativ.

En distinktion mellan olika typer av nudges görs av den australienska regeringen (The Australian Government, na) baserat på huruvida de är reglerande för företag eller inte. Två olika grupper definieras: "rena" respektive nudges som behöver föregås av reglering. En ren nudge innebär ett ingripande som förändrar valarkitekturen utan att lägga ytterligare krav på företagen (som att skicka ut förifyllda skatteblanketter), medan den andra kategoriseringen kräver att företag ändrar sin nuvarande praxis, exempelvis för att utforma information på ett visst sätt. Detta kan behöva föregås av reglering.

\subsubsection{Nudging används idag endast i liten skala - mer kunskap skulle kunna öka intresset}

De som skulle kunna arbeta med nudging gör inte det i någon större utsträckning. Vi har intervjuat representanter främst på kommunnivå i Sverige, och de säger sig vara intresserade av att använda insikter från beteendeekonomin men att de saknar kunskap om hur man kan och bör gå tillväga. Intervjustudien visar också att de som arbetar med insamling av elektronik anser att det är viktigare med andra styrmedel än nudging, insatser som till exempel förbättrar producentansvaret eller möjligheterna till reparation, se Box 7.

Ett problem är att insamlad elektronik på många sätt är svår att ta hand om på ett hållbart sätt. Exempelvis innehåller en modern mobiltelefon omkring 40 olika metaller som kanske återfinns i för liten mängd för att det ska vara lönsamt att ta vara på dem (SGU, 2014). Metaller kan också finnas i designen, blandat med andra material, vilket försvårar återvinningen eller gör att materialet inte lämnas till materialåtervinning.

\footnotetext{
att exempelvis använda mindre tallriksstorlekar är detta - enligt den traditionella definition av nudging givet ett implicit antagande att de som tar mat vill minska sin matkonsumtion, även om detta inte är fallet. Valet för den som utformar alternativen står mellan att nudga mot att ta mer mat (genom större tallrikar) eller mindre mat (genom mindre tallrikar) och väljer i fallet mindre tallrikar att nudga mot det senare alternativet. Gränserna mellan vad som är uttalade attityder och antagna attityder är därmed inte alltid tydlig. Det är viktigt att återigen påpeka att man att nudging i det här fallet inte heller begränsar möjligheten för de som inte vill begränsa sin matkonsumtion - dessa kan ta kan ta mat flera gånger. Det är dock i realiteten inte alltid tydligt vad som är individens preferenser, och vad den nudgar bestämmer.
} 
Box 7. Intervjupersoner ser andra insatser som mer relevanta för att öka återanvändning och återvinning av elektronik

Nudging kan spela en roll vad gäller exempelvis design av återvinningsstationer för att guida konsumenter. Dock anger intervjupersonerna att tillgänglighet är det främsta problemet när det gäller återvinning av elektronik, det vill säga att det inte finns tillräckligt många ställen att lämna in sitt återvinningsmaterial på. Här kan administrativa styrmedel ha en större vikt än nudging. Detta har man tagit fasta på i Finland. Det var tidigare svårt för konsumenter som bor i stadskärnor, exempelvis i Helsingfors, att göra sig av med sitt elektronikavfall eftersom de flesta återvinningsstationerna var placerade utanför stadskärnan. Ny lagstiftning som ställer krav på att fler platser (främst butiker) ska ta emot elektronik har dock gjort att konsumenter nu har fler ställen att lämna sina små och stora apparater.

Flera av intervjupersonerna menar att ett av de största hindren för hållbar konsumtion av elektronik är det faktum att reparation av elektronikprodukter i många fall är dyrt, krångligt och tekniskt omöjligt. Detta, kombinerat med låga priser för nya elektronik, gör att konsumenter inte uppmuntras att reparera sina produkter, och i viss mån avskräcks från att köpa begagnat.

Ett ytterligare hinder som nämndes, främst för återanvändning av elektronik, är att producentansvaret täcker använda produkter som någon exempelvis hämtar från en återvinningscentral där de ska skrotas. Den producent som satt produkten på marknaden ansvarar för dess säkerhet även $\mathrm{i}$ detta fall, vilket gör att företag helst inte ser att konsumenter t.ex. reparerar produkter själva eftersom producenten är ansvarig om lagningen blir farlig.

Intervjupersonerna tror främst på andra insatser än nudging för att öka återvinningen och återanvändningen av elektronik. Exempelvis nämns ekonomiska styrmedel såsom pantsystem för elektronik (mobiltelefoner i synnerhet) och ett reparationsavdrag för att det ska bli billigare för hushåll att laga saker (ett så kallat REP-avdrag) som bland annat har företagits av Naturvårdsverket (Naturvårdsverket, 2015).

Källa: Copenhagen Economics baserat på intervjuer med representanter för El-kretsen i Sverige, Samkommunen Helsingforsregionens miljötjänster HRM, Energimyndigheten i Sverige, Dansk Kompetencecenter for Affald (DAKOFA) och Karlstads kommun. 
Figur 21 sammanfattar de huvudsakliga policyimplikationerna av dessa resultat. Implikationerna är segmenterade på olika nivåer, baserat på vilken typ av aktörer de riktar sig mot. På den första nivån finns regeringar i de nordiska länderna, som definierar miljö- och hållbarhetspolitiken. På den andra nivån finns genomförare, och på den tredje finns utvärderare. Som kunskapsspridare och hjälp finns nordiska organisationer som Nordiska ministerrådet. De olika rekommendationerna beskrivs mer utförligt nedan.

Figur 21: Generella policyrekommendationer kring nudging och hållbar konsumtion

Nordiska ministerrådet/nordiska organisationer

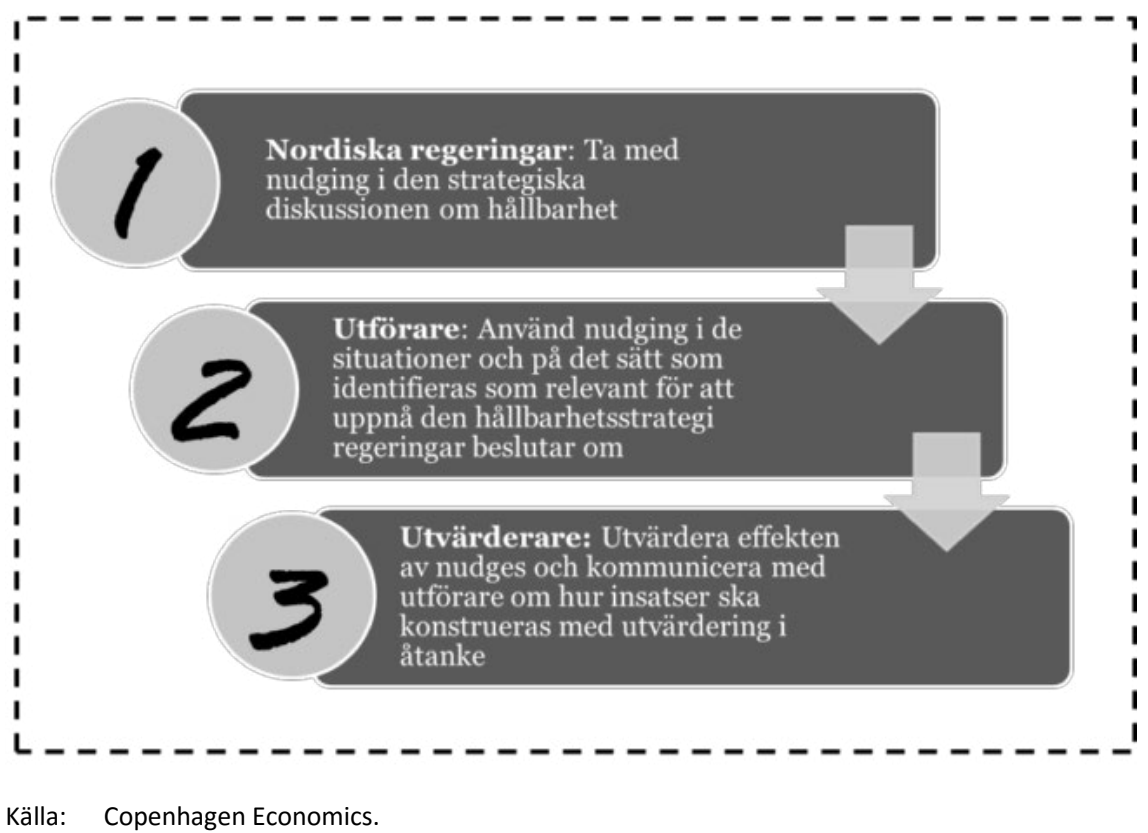

1. Regeringar: Den strategiska diskussionen om hållbarhetspolitik bör inkludera nudging som ett potentiellt verktyg. Strategier för att öka hållbar konsumtion bör gå ut på att lösa de identifierade problemen, och definiera hur. Strategin bör alltså inte vara låst till ett eller vissa verktyg utan syftet måste vara att problemen ska lösas med hjälp av de mest lämpliga verktygen. Nudging kan vara en självständig del detta, men kan också vara en del i ett övergripande styrmedelspaket, exempelvis som komplement till andra styrmedel eller för att förstärka effekten av dessa.

2. Utförare: Utförande aktörer som kommuner eller operativa myndigheter bör arbeta med nudging i den utsträckning det passar in i deras övergripande uppdrag. Vi har intervjuat representanter 
främst på kommunnivå i Sverige, och de säger sig vara intresserade av att använda insikter från beteendeekonomin men att de saknar kunskap om hur man kan och bör gå tillväga. En allmän vägledning till nudging för miljöarbete skulle kunna bidra till ökad kunskap och samsyn kring nyttan och utmaningarna med nudging. Den bör innehålla tydliga steg - beteendekartläggning, analys och problemidentifiering, lösning/nudgingdesign, utvärdering och lärande - med praktiska exempel som kan hjälpa organisationer som vill arbeta med nudging att göra detta på ett strukturerat sätt.

3. Utvärderare: Det kan inte nog understrykas att kunskapen om vilka effekter nudging kan ha är outvecklad och att insamling av uppgifter som möjliggör utvärdering och lärande bör vara en central del av varje nudgingprojekt. Nudges bör konstrueras med utvärdering $\mathrm{i}$ åtanke, och utvärderande myndigheter i de nordiska länderna bör ges i uppdrag att utvärdera effektiviteten i insatserna. För att göra detta behöver utvärderare kunskap om nudging. Återkoppling och lärande behöver också ske mellan utförare och utvärderare.

Nordiska ministerrådet och andra nordiska organisationer kan hjälpa till att sprida kunskap om vad som lyckas och inte i de olika nordiska ländernas arbete med nudging, samt harmonisera processerna. Slutligen, för att nudging ska lyckas måste konsumenterna känna ett stort förtroende för utföraren. De aktörer som har lågt förtroende bland sin målgrupp kan räkna med lägre effekt av nudginginsatser än aktörer med högt förtroende.

\subsection{Observationer och rekommendationer angående nudging och mobiltelefonmarknaden}

För att undersöka konsumentbeteenden på en specifik marknad har vi genomfört ett pilotexperiment som rör konsumtion av mobiltelefoner bland ungdomar i åldrarna 19 till 28 år. Pilotstudien inleds med en beteendekartläggning av hur ungdomar beter sig när de köper, använder och återvinner mobiltelefoner, och utformar och testar därefter nudges för att påverka dessa i en mer hållbar riktning. 


\subsubsection{Potentiellt stor effekt av nudging för ungdomars konsumtion av mobiltelefoner}

Vi finner, baserat på resultaten av pilotstudien, att nudging potentiellt kan ha stor effekt för att öka hållbar konsumtion av mobiltelefoner bland ungdomar, speciellt för att öka reparation och köp av begagnat. ${ }^{25}$ Eftersom detta är en pilotstudie bör resultaten tolkas med försiktighet, men de ger en indikation på potentialen. Ungdomar verkar ha en preferens för att agera hållbart - många vill till exempel reparera mobilen när den går sönder - men kan eller gör inte alltid detta. En förklaring är att ungdomar vid köptillfällen och beslut om att reparera har bristande information, låg medvetenhet och att somliga beslut har hög komplexitet. Bristande information gäller främst möjligheterna att reparera och köpa begagnat (det kräver mer insats att hitta en reparatör eller återförsäljare av begagnat än att köpa en ny telefon på samma ställe som förra gången), låg medvetenhet innebär att man inte söker information utan gör ett val delvis baserat på vad man gjort tidigare (man går till den butik där man köpte sin förra telefon) och hög komplexitet (det finns många alternativ för konsumenten att utvärdera och välja mellan, man vet inte hur mycket en reparation kostar om denna kommer lyckas och om kostnaden täcks av en garanti etc.).

Dessa begränsningar hindrar många ungdomar från att välja eller överväga reparationer eller begagnade mobiler som ett alternativ till att köpa en ny mobil. Nudging som övervinner de identifierade beteendehindren kan här spela en roll för att hjälpa ungdomar agera i linje med sina preferenser; att $i$ högre utsträckning välja gröna lösningar (reparationer eller begagnade mobiler).

Vi testade olika nudges i två kontrollerade experiment i en simulerad köpsituation, och resultaten sammanfattas i Tabell 4. De identifierade lösningarna valdes för att dessa områden bedöms ha störst potential när det gäller att påverka ungdomars beteende i en hållbar riktning, det vill säga områden där ungdomar behöver hjälp med att agera i enlighet med sina preferenser. Eftersom detta är en pilotstudie hade vi inte möjlighet att genomföra experimentet i en faktisk köpsituation eller ta hänsyn i hur resultaten specifikt kan appliceras. Syftet med studien var dock inte att besvara samtliga frågor om utan att ge en indikation på om det finns en potential för nudging mot mer hållbar konsumtion av mobiltelefoner

\footnotetext{
${ }^{25}$ En risk med att ungdomar verkar mottagliga för nudging är att det den etiska dimensionen kan komma att debatteras (se också den diskussion om etiska aspekter som förs i box 4). Att ungdomar är "påverkbara" gör att insatser behöver designas med stor försiktighet. I de experiment vi har utfört kan de nudges som använder decoy-effekten sannolikt möta större motstånd än de två andra som framhåller information vid en viss tidpunkt.
} 
bland ungdomar, och i så fall var den finns. Då potentialen verkar finnas till största delen för att öka reparationer och köp av begagnat rekommenderar utför vi experiment främst inom detta område. Fler resultat av beteendekartläggningen beskrivs i kapitel 3 och i bilaga D.

Tabell 4: Resultat av experiment i pilotstudie

$\begin{array}{lll}\text { Nudge } & \text { Beskrivning } & \text { Effekt } \\ \begin{array}{l}\text { Experiment 1 } \\ \begin{array}{l}\text { Nudging för ökade } \\ \text { reparationer }\end{array}\end{array} & \begin{array}{l}\text { Alternativet "reparation" framhålls i } \\ \text { samband med erbjudande om en ny } \\ \text { telefon, i en simulerad köpsituation }\end{array} & \text { Nudge ger statistiskt signifikant skillnad } \\ \begin{array}{l}\text { Nudging för } \\ \text { begagnade } \\ \text { telefoner }\end{array} & \begin{array}{l}\text { Alternativet "begagnad telefon" framhålls i } \\ \text { samband med erbjudande om en ny } \\ \text { telefon, i en simulerad köpsituation }\end{array} & \text { Nudge ger statistiskt signifikant skillnad } \\ \begin{array}{l}\text { Experiment 2 } \\ \text { Nudging för ökad } \\ \text { leasing }\end{array} & \begin{array}{l}\text { En decoy (ett icke-relevant alternativ) läggs } \\ \text { till i en simulerad köpsituation }\end{array} & \text { Nudge ger statistiskt signifikant skillnad } \\ & \begin{array}{l}\text { En decoy (ett icke-relevant alternativ) läggs } \\ \text { Nudging för "gröna } \\ \text { telefoner" }\end{array} & \begin{array}{l}\text { Nill i en simulerad köpsituation } \\ \hline\end{array}\end{array}$

Källa: Copenhagen Economics.

Experimenten visar att ungdomar verkar ha en preferens för att agera hållbart - många vill till exempel reparera mobilen när den går sönder men kan eller gör inte alltid detta. Att framhålla dessa alternativ vid köptillfället kan spela en roll i att hjälpa dem agera enligt sina preferenser. Experimenten visar också att leasing verkar vara ett alternativ som tilltalar somliga. Ökad leasing är dock inte nödvändigtvis önskvärt ur miljöhänsyn. Å ena sidan kan uthyrning av telefoner skapa incitament för företag att tillverka mer långlivade produkter. Å andra sidan finns det en risk för att konsumenter byter den hyrda telefonen så fort en ny modell kommer ut på marknaden, vilket kan öka omsättningen av mobiltelefoner på aggregerad nivå. I förlängningen kan dock den gamla telefonen hyras ut till någon annan, och om denna efterfrågan är stark nog kan ett mindre antal telefoner behövas för populationen som helhet. Nettoeffekten av dessa resultat är såklart svår att uppskatta.

Den nudge vi testade för att öka valet av "gröna" mobiler jämfört med konventionella alternativ visade sig verkningslös i experimentet, något som kan ha flera möjliga förklaringar. Exempelvis kan ekonomiska incitament tränga ut övriga motiv såsom viljan att agera miljövänligt. Att rabattera en miljövänlig produkt (som konsumenter är villiga att betala mer för) förflyttar medvetenheten till just priset, vilket får konsumenten 
att fokusera mer på detta än på det faktum att man gör något bra för miljön, och avstår från den miljövänliga varan eftersom denna är dyrare.

Det är återigen viktigt att poängtera att resultaten ska tolkas med försiktighet då de baseras på en pilotstudie som är utförd i en simulerad köpsituation, och alltså inte testats i en faktisk situation. Det är därmed inte möjligt att säga hur och i vilken skala resultaten går att använda.

\subsubsection{Marknadens struktur hindrar eventuellt användning av nudging}

Det finns en inbyggd problematik i att överföra ovanstående observationer till verkligheten: marknaden för mobiltelefoner har idag inte den typ av aktörer som skulle krävas för att implementera resultaten. Återförsäljare av mobiltelefoner erbjuder idag generellt inte reparation, och i begränsad utsträckning begagnade telefoner. Det ligger därmed inte i deras intresse att framhålla dessa alternativ utan att bredda sitt erbjudande. Att påminna om möjligheter utanför företagets verksamhet skulle leda till minskad försäljning i butiken, vilket gör att återförsäljare inte har incitament att göra detta. Producenter av mobiltelefoner drivs också av företagsekonomiska motiv att sälja stora kvantiteter och på så sätt att göra vinst, och har därmed heller inte incitament att i dagens läge framhålla andra alternativ. Dessutom finns en rad andra hinder för hållbar konsumtion av mobiltelefoner som har med marknadens struktur att göra, exempelvis de abonnemang som operatörer erbjuder, planerad utfasning där mobiltelefoner blir obrukbara efter ett visst antal uppdateringar av mjukvara. Snabb teknikutveckling gör också telefoner utdaterade innan dess faktiska livslängd är över.

Den här studien utgår från konsumenternas perspektiv. För att fullt kunna använda resultaten behövs, i tillägg till ytterligare studier på detta område, en analys som utgår från producenter och återförsäljare på mobiltelefonmarknaden. För att applicera insikter om nudging för mobiltelefoner behöver vi veta i vilka fall de företagsekonomiska motiven är jämkade med de samhällsekonomiska, och i vilka fall dessa står i motsatsförhållande till varandra. I det föregående fallet kan fungerande nudging i butiker eventuellt behöva understödjas av reglering av exempelvis vilken information affärer behöver visa vad gäller reparationskostnader, begagnade telefoner och "gröna" alternativ. I det sistnämnda fallet är insatser antagligen mindre komplicerade. Exempelvis kan återförsäljare av begagnade telefoner samt ställen som reparerar mobiltelefonen antas ha incitament att nudga konsumenter mot dessa alternativ, exempelvis med hjälp av jämförelsepriser mellan 
nya och begagnade telefoner. Dessa marknader är dock relativt outvecklade idag, och behöver fungera väl för att konsumenter ska välja dessa alternativ, och tjäna på valen.

Baserat på dessa slutsatser ger vi följande rekommendationer för vidare studier som fokuserar på mobiltelefonmarknaden:

- Marknadsanalys, med fokus på återförsäljare producenters incitament. Analys av vilka drivkrafter systemets aktörer har idag, och hur dessa förhåller sig till de samhällsekonomiska motiven att öka hållbarheten i konsumtion av mobiltelefoner Att företag idag agerar på incitament som leder dem i linjär, i motsats till cirkulär, riktning är ett av de större hindren för hållbar konsumtion av elektronik enligt intervjupersoner, se Box 8. En möjlig studie skulle kunna identifiera de specifika incitament som styr företags produktion av mobiltelefoner, liksom återförsäljares motsvarighet. Syftet med detta är att bedöma vilka styrmedel som mest effektiv kan styra mot hållbar konsumtion. En bredare studie kan fokusera på dessa incitament för elektronik generellt, och även analysera hur nya affärsmodeller kan påverka resurseffektivitet. Mest intressant är modeller som fokuserar på delning och uthyrning, och som eventuellt kan ge upphov till mer långlivade elektronikprodukter.

- Fungerande marknad för reparation. Fler och fler företag erbjuder reparation av mobiltelefoner, men marknaden kännetecknas av osäker kvalitet. Statliga aktörer, såsom konsumentverk i de olika länderna, kan spela en roll för att stärka trenden mot ökad reparation och begagnat genom göra det lättare för konsumenterna att välja en bra utförare. Exempelvis kan man underlätta informering om vilka produkter som ingår i en reparation och som fungerar för olika modeller (olika typer av skärmar, batterier etc.) och att göra det enkelt att jämföra priser. En lista kan skapas som för olika produkter visar huruvida konsumenten behåller sin garanti vid reparationer, om reparationen kommer med ny garanti etc. Detta skulle också underlätta för prisjämförelser. Som förslag kan en workshop hållas med olika intressenter, däribland reparationskedjor, för att undersöka vad en sådan lista kan och bör innehålla.

- Fullskaligt nordiskt projekt om nudging och mobiltelefoner, med fokus på det vi funnit viktigt i pilotstudien. Ett sådant projekt bör främst gälla möjligheterna att använda nudging för att öka reparationer av trasiga telefoner och köp av begagnat. Exempelvis går det att göra experiment med jämförelsepriser över telefoners livstid - vad kostar reparation jämfört med en ny telefon, sett till 
hur länge man har telefonen? En utökad studie skulle anta ett bredare nordiskt perspektiv med nya data från samtliga nordiska länder. Då blir det möjligt att exempelvis analysera skillnader i konsumtionsbeteende mellan män och kvinnor samt mellan de nordiska länderna. En fullskalig studie bör också ha ett tydligt fokus på implementering av resultaten.

Box 8. Enligt intervjupersoner spelar företags affärsmodeller stor roll för hållbar konsumtion av elektronik

Ett av de största hindren för hållbar konsumtion av elektronik är enligt intervjupersonerna att företags affärsmodeller ofta skapar incitament för konsumenter att köpa nya produkter innan de gamla egentligen är förbrukade. Exempelvis inkluderar vissa affärsmodeller planerat åldrande, det vill säga att göra en produkt oanvändbar när den skulle kunna fungera. Bland annat produceras elektroniska apparater med kort livslängd i syfte att öka konsumtionen. Det finns tydliga exempel på affärsmodeller som motverkar hållbar konsumtion av elektronik, bland annat mobiltelefoner med olika abonnemang där telefonens kostnad inkluderas i abonnemangets kostnad och längd. När abonnemanget löper ut får konsumenten känslan av att det också är dags för en ny telefon (Luttropp et al. 2013). Eftersom det samtidigt blivit allt billigare med elektronik uppmuntras konsumenter att välja nyproducerat $\mathrm{i}$ stället för att reparera eller köpa begagnade varor.

En typ av affärsmodell som ger motsatt verkan är uthyrning av produkter i stället för försäljning. Exempelvis produceras nu tonerkassetter med hög kvalitet eftersom dessa byts ut flera gånger och därmed behöver vara slitstarka. Att stödja affärsmodeller som fokuserar på uthyrning faller utanför konceptet nudging, men är eventuellt ett sätt att öka hållbar konsumtion av elektronik. Slutligen observerar intervjupersonerna att ökad efterfrågan på hållbara produkter har gjort att fler och fler företag säljer sådana eftersom det ger en konkurrensfördel. Även detta faller utanför nudging som styrmedel, men det är en utveckling som kan stödjas med hjälp av styrmedel som ökar efterfrågan på hållbara produkter. Nudging eller beteendeekonomi kan här spela en roll i utformningen av sådana styrmedel.

Källa: Copenhagen Economics baserat på intervjuer med representanter för El-kretsen i Sverige, Samkommunen Helsingforsregionens miljötjänster HRM, Energimyndigheten i Sverige, Dansk Kompetencecenter for Affald (DAKOFA) och Karlstads kommun. 
Nudging och beteendeekonomi är växande och delvis outforskade områden, och användningen av nudging har fortfarande begränsningar som troligtvis behöver överkommas innan metoden blir accepterad på större skala (oavsiktliga biverkningar, svårigheter att överföra nudges från kontrollerade experiment till faktiska förhållanden, långsiktiga effekter, etc.). För att avhjälpa begränsningarna behövs mer forskning och förståelse för hur nudging kan användas effektivt, och var verktyget ger störst effekt. Vi rekommenderar starkt fortsatt forskning på området, för att skapa legitimitet för användning av nudging och större förståelse för var insatser ger störst effekt. 


\section{Referenser}

Ariely, D. (2008). Predictably Irrational: The Hidden Forces That Shape Our Decisions. HarperCollins Publishers, New York.

Baldé, C., Wang, F., Kuehr, R., \& Huisman, J. (2014). The global e-waste monitor 2014. Bonn: United Nations University, IAS - SCYCLE.

Barkman, H. (2014). Barriärer och broar för hållbar konsumtion - Fyra typer av medborgarkonsumenter och möjligheterna för deras engagemang. Licentiatavhandling, Stockholms universitet.

Christensen, T. H., Godskesen, M., Gram-Hanssen, K., Quitzau, M.-B., \& Røpke, I. (2007). Greening the Danes? Experience With Consumption and Environment Policies. Journal of Consumer Policy, 30:91-116. http://dx.doi.org/10.1007/ s10603-007-9029-2

Engel, J. F., Blackwell, R. D., \& Kollat, D. T. (1978). Consumer Behavior. The Dryden Press, Texas.

EU-kommissionen. (den 7 augusti 2015). Waste Electrical \& Electronic Equipment (WEEE). Hämtat från (http://ec.europa.eu/): http://ec.europa.eu/ environment/waste/weee/index_en.htm

Europaparlamentet. (den 4 juli 2012). Europaparlamentets och Rådets Direktiv 2012/19/EU av den 4 juli 2012 om avfall som utgörs av eller innehåller elektrisk och elektronisk utrustning (WEEE) (omarbetning) (Text av betydelse för EES). Europeiska unionens officiella tidning, ss. L 197/38-71. Hämtat från http://eur-lex.europa.eu/legal-content/SV/TXT/PDF/ ?uri=CELEX:32012L0019\&from=SV

Fischbacher, U., Gächter, S., \& Fehr, E. (2001). Are people conditionally cooperative? Evidence from a public goods experiment. Economics Letter volum 71, upplaga 3, juni 2001, p. 397-404.

Frederiks, E. R., Stenner, K., \& Hobman, E. V. (2015). Household energy use: Applying behavioural economics to understand consumer decision-making and behaviour. Renewable and Sustainable Energy Reviews 41, 1385-1394. http://dx.doi.org/ 10.1016/j.rser.2014.09.026

Hansen, P. G., \& Jespersen, A. M. (2013). Nudge and the manipulation of choice - A Framework for the Responsible Use of the Nudge Approach to Behaviour Change in Public Policy. The European Journal of Risk Regulation, Vol. 1, 3-28.

John, P., Cotterill, S., Moseley, A., Richardson, L., Smith, G., Stoker, G., \& Wales, C. (2013). Nudge, Nudge, Think, Think - Experimenting with Ways to Change Civic Behaviour. London: Bloomsbury Academic.

Johnson, E. J., \& Goldstein, D. (2003). Do Defaults Save Lives? sciencemag.org, 21 november 2003, vol 302.

Kahneman, D. (2011). Thinking, fast and slow. 1st ed. New York: Farrar, Straus and Giroux.

Kallbekken, S., Sælen, H., \& Hermansen, E. A. (2012). Bridging the Energy Efficiency Gap: A Field Experiment on Lifetime Energy Costs and Household Appliances. Journal of Consumer Policy, mars 2013, volum 36, upplaga 1, p 1-16. 
Knussen, C., \& Yule, F. (2008). "I'm Not in the Habit of Recycling” - The Role of Habitual Behavior in the Disposal of Household Waste. Environment and Behavior, September 2008, Vol. 40 no. 5, 683-702. http://dx.doi.org/10.1177/0013916507307527

Konjunkturinstitutet. (2012). Miljö, ekonomi och politik. Stockholm: Konjunkturinstitutet.

Laibson, D. (1997). Golden eggs and hyperbolic discounting. The Quarterly Journal of Economics, maj 1997.

Luttropp, C., Börjesson Rivera, M., \& Henriksson, G. (2013). Drivkrafter bakom uppkomsten av elavfall - Ett produkt- och konsumtionsperspektiv. Naturvårdsverket: Rapport 6575.

Löf, A. (2013). Förutsättningar och hinder för att minska elektronikavfall. Södertörns högskola, Institutionen för Naturvetenskap, Miljö och Teknik, Kandidatuppsats 15 hp

Marteau, T. M., Ogilvie, D., Roland, M., Suhrcke, M., \& Kelly, M. P. (2011). Judging nudging: can nudging improve public health? BMJ, Vol. 342. http://dx.doi.org/10.1136/ bmj.d228

Mellström, C., \& Johannesson, M. (2008). Crowding out in blood donation: Was Titmuss right? Journal of the European Economic Association, volum 6, upplaga 4, p 845-863, juni 2008.

Mobilbusiness. (den 11 November 2014). Svenskarna slår rekord i att använda surfplattor. Hämtat från (http://mobilbusiness.se/):

http://mobilbusiness.se/article/svenskarna-slar-rekord-i-att-anvanda-surfplattor\#.VVB3ffntlBd

MobilTeleBranschen. (10 maj 2015). Mobiltelefonförsäljningen i Sverige. Hämtat från (mtb.se): http://www.mtb.se/index.php?sid_id=1281\&id=1281\&ftg=41\&ftg_id=41

Mont, O., Lehner, M., \& Heiskanen, E. (2014). Nudging - Ett verktyg för hållbara beteenden? Naturvårdsverket, rapport 6642.

Naturvårdsverket. (2015). Tillsammans vinner vi på ett giftfritt och resurseffektivt samhälle - Sveriges program för att förebygga avfall 2014-2017. Rapport 6654.

Norwegian Water Resources and Energy Directorate. (2013). Energy consumption 2012 - Household energy. Report no. 16/2013.

SGU. (2014). Uppdrag att utföra en kartläggning och analys av utvinnings- och återvinningspotential för svenska metall- och mineraltillgångar.

Skatteverket. (2005). Rätt från början - Forskning och strategier. Rapport 2005:1.

Stockholm Environment Institute. (2015). Styrmedel och andra insatser för att minska svensk konsumtions påverkan på hälsa och miljö i andra länder. Working Paper 2015-03.

Sunstein, C. R., \& Reisch, L. A. (2013). Green by Default. Kyklos, Volume 66 (3), 398402. http://dx.doi.org/10.1111/kykl.12028

Synovate. (2009). Vardagen och miljön. Konsumentverket.

Thaler, R. H., \& Sunstein, C. R. (2008). Nudge: Improving Decisions about Health, Wealth, and Happiness. Yale University Press. New Haven.

The Australian Government. (na). Influencing Consumer Behaviour - Improving Regulatory Design. OBPR Research Paper.

The Washington Post. (den 2 april 2007). The Decoy Effect, or How to Win an Election. Hämtat från The Washington Post: 29 september 2015

http://www.washingtonpost.com/wp-dyn/content/article/2007/04/01/

AR2007040100973.html 
Tversky, A., \& Kahneman, D. (1992). Advances in Prospect Theory: Cumulative Representation of Uncertainty. Journal of Risk and Uncertainty, volum 5, upplaga 4, s 297-323.

Verplanken, B., \& Wood, W. (2006). Interventions to Break and Create Consumer Habits. Journal of Public Policy \& Marketing, Vol. 25 (1), 90-103. http://dx.doi.org/ 10.1509/jppm.25.1.90

Xrgia. (2011). Hovedundersøkelse for elektrisitetsbruk i husholdningene. För NVE.

Öhrlund, I. (2012). Insamling av elektriskt och elektroniskt avfall - En fallstudie av två svenska kommuner. Examensarbete i Hållbar Utveckling vid Uppsala universitet, $71 \mathrm{pp}, 30 \mathrm{ECTS} / \mathrm{hp}$. 


\section{English summary}

\section{Increased consumption of electronic goods}

Consumption of electronics has increased steadily in the Nordic countries over the past two decades, creating an associated increase in amounts of electronic waste. Increased consumption of electronic goods cause a number of environmental problems, such as local environmental and health problems associated with the extraction of materials used in electronics and in the management of electronic waste, as well as increased electricity consumption. The main measure to offset the trend of increased consumption of electronics is producer responsibility, which means the seller of any electronic good has the responsibility for the waste generated by the sale. A theoretical advantage of the system is that producers - by having responsibility for the product's ultimate goal - are encouraged to minimise the collection and recycling costs in the production phase. The system displays certain practical shortcomings, however, such as the fact that waste collection is done collectively, which means individual companies' efforts to minimise the use of materials gives small effect on the total; the gains benefit all participants in the system and not the investing company.

\section{Consumer-oriented instruments to counteract the development}

There is a growing awareness that policies targeting the supply side (production) needs to be complemented by measures targeting the demand side (consumption) to enable individuals to make more sustainable choices. This includes actions that induce consumers to buy fewer electronical goods, more environmentally friendly or long-lived electronic goods, use products they own longer, and increase the re-use as well as recycling of electronics.

Most consumer-oriented instruments for sustainable consumption are based on a neoclassical economic view of consumers as economically rational. This assumption has partially proved insufficient when it comes to predicting and influencing behaviour, as consumers often differs from the path predicted by economics models. Behavioural economics aims to 
identify and understand these differences, in order to more accurately predict and influence how consumers behave. This knowledge is also increasingly used to design policy instrument. The insights from behavioural economics facilitates understanding for decision-makers of human behaviour and factors affecting behavioural change, but can also make strategies promoting sustainable consumption more effective.

\section{Nudging for sustainable consumption}

This report focuses on the possibility to use nudging to increase sustainable consumption of electronics: to encourage or "nudge" consumers towards more sustainable consumption choices. A nudge can be defined as a way to design a situation of choice and the way options are presented (also called choice architecture), in order to change people's behaviour in a predictable way without eliminating their opportunities or change their incentives. The objective of introducing a nudge is to help individuals make the decisions they would have made if they had been aware, had full information and complete self-control. The reasons consumer do not make these choices in the first place can range from a number of factors: doing things requires energy; we are prone to procrastinate and forget to do things - even though we know we should. Many decisions are fundamentally complex with a large number of choices, uncertain outcomes and different aspects to be balanced. Other decisions are made in a routine manner, without us considering our actions. We are affected by what our friends think and do, what we believe to be accepted by society, what we think is expected of us, etc. There are, in conclusion, a number of different factors playing into people's decision of whether to act or not to act sustainably in different situations. In the report, we investigate the most important factors that affect consumption of electronics, and how nudging has been used and can be used to increase sustainable consumption of electronic goods.

\section{There is theoretical potential for nudging}

The results of the study show that there is a theoretical potential to use nudging to promote sustainable consumption of electronic products, mainly in the purchase of new electronics, but also to get people to use products longer (for example by increasing repairs). No studies have, to the best of our knowledge, investigated the specific effects of nudging on electronic consumption; rather, we map behaviour and nudges from surrounding areas that may also be relevant for electronic consumption. This is done summarily since behaviour differs significantly between different 
types of purchases of electronics (small electronic goods, household appliances, etc.), different stages of the consumption process (purchase, decisions to re-use, decision to recycle etc.) and various demographic groups (young people versus the elderly, etc.). The research literature in this area is very clear on the fact that nudging is primarily effective for promoting behavioural change in a specific context, and that results from one situation cannot arbitrarily be generalised to other contexts or to a wider population.

\section{Pilot study of nudging and sustainable consumption of mobile phones}

In a pilot study, we therefore dig deeper into a specific category of consumer behaviour of electronics: consumption of mobile phones in the age group 19 to 28 years in the Nordic countries. We first conduct a survey of young people's consumption of mobile phones, in order to identify if there are unintended behaviours or behavioural obstacles that inhibit sustainable consumption. A number of observations suggest that this is the case, which means nudging may have a role to play. For example, we note that relatively many young people chose to buy a new phone when their old one is broken, without investigating whether it would be possible to repair the old one. We also note that young people - when they buy a new phone - often routinely go to the shop where they bought their previous phone. Another interesting observation is that young people have a certain environmental awareness and willingness to pay for "green" mobile phones as well as leasing services.

We conducted two controlled experiments testing the effect of various nudges on young people's consumption decisions. In the first experiment, we examine how nudging can influence the decision to buy a new mobile phone when the old one is broken. The nudge investigated is "active display" of two alternative options to buying a new phone: to repair an old one or to buy a used phone. In the second experiment, we examine how nudging can increase leasing and purchases of "green" mobile phones. This is done by introducing a so-called decoy. The rationale for the decoy effect is that it can be difficult to choose between two options where none is objectively better than the other one. The choice is affected by introducing a third option that is objectively worse than one of the other two choices. It is for example possible to introduce a leased phone in a situation of a choice, which has less favourable terms than another leased phone in order to nudge towards the first phone. 
The experiments show that young people seem to have a preference for sustainable behaviour - for example, many want to repair their broken phone - but can or do not always do this. Emphasising sustainable alternatives at the time of purchase can play a role in helping young people act according to their preferences. The experiments also show that leasing seems to be an alternative that appeals to some. The nudge we tried to increase the choice of "green" phones compared to conventional alternatives proved to be ineffective in the experiment.

Table: Results of experiments in pilot study

\begin{tabular}{|c|c|c|}
\hline Nudge & Description & Effect \\
\hline \multicolumn{3}{|l|}{ Experiment 1} \\
\hline $\begin{array}{l}\text { Nudging for in- } \\
\text { creased repairs }\end{array}$ & $\begin{array}{l}\text { The possibility to repair an old phone is } \\
\text { highlighted in connection with the offer to } \\
\text { purchase a new phone, in a simulated pur- } \\
\text { chasing situation }\end{array}$ & $\begin{array}{l}\text { Nudge creates a statistically significant } \\
\text { change }\end{array}$ \\
\hline $\begin{array}{l}\text { Nudging for used } \\
\text { phones }\end{array}$ & $\begin{array}{l}\text { The possibility to buy a used phone is high- } \\
\text { lighted in connection with the offer to pur- } \\
\text { chase a new phone, in a simulated purchas- } \\
\text { ing situation }\end{array}$ & $\begin{array}{l}\text { Nudge creates a statistically significant } \\
\text { change }\end{array}$ \\
\hline \multicolumn{3}{|l|}{ Experiment 2} \\
\hline $\begin{array}{l}\text { Nudging for in- } \\
\text { creased leasing }\end{array}$ & $\begin{array}{l}\text { A decoy (a non-relevant alternative) are } \\
\text { added to a simulated purchasing situation }\end{array}$ & $\begin{array}{l}\text { Nudge creates a statistically significant } \\
\text { change }\end{array}$ \\
\hline $\begin{array}{l}\text { Nudging for "green } \\
\text { phones" }\end{array}$ & $\begin{array}{l}\text { A decoy (a non-relevant alternative) are } \\
\text { added to a simulated purchasing situation }\end{array}$ & $\begin{array}{l}\text { Nudge does not create a statistically signifi- } \\
\text { cant change }\end{array}$ \\
\hline
\end{tabular}

Källa:: Copenhagen Economics.

\section{Market structure might prevent the use of nudging}

There is an inherent problem in transferring the above observations to reality: the mobile phone market today does not have the kind of players that would be required to implement the results. Retailers of mobile phones generally do not offer repairs, and only to a limited extent used phones. It is therefore not in their interest to highlight these options. Rather the opposite, since emphasising options outside of the company would lead to reduced sales in the store. Producers of mobile phones also have economic incentives to sell large quantities to increase profits, again reducing their incentives to highlight more sustainable options. In addition, there are a number of other obstacles to sustainable consumption of mobile phones related to the structure of the market, for example the sub- 
scriptions operators offer, and planned obsolescence which render mobile phones non-functional after a certain number of upgrades of software. Rapid technological development also make phones outdated before their actual lifetime is over.

This study starts from a consumer perspective. In order to make full use of the results, in addition to further studies in this area, an analysis based on the producers and distributors in the mobile phone market is needed. To apply insights about nudging regarding mobile phones we need to know in which cases the business incentives are aligned with socioeconomic incentives, and in which cases these are in conflict with each other. In the latter case, implementing nudging in stores may require underpinning regulation, for example, regarding information companies need to show in terms of repair costs, used phones and "green alternatives". In the latter case, nudges towards sustainable choices is likely less problematic. For example, dealers of used phones and repair shops presumably have incentives to nudge consumers towards these options, e.g. by displaying comparative prices for new and used phones. These markets are however relatively undeveloped today, and need to work well for consumers to choose these options, and profit from their choices.

\section{Policy recommendations}

The figure below summarises the main policy implications we draw from the study's results. The implications are segmented on different levels, based on the type of players they target. On the first level are governments of the Nordic countries, which mandate environmental policy. On the second level are implementers of said policy and on the third level are evaluators. For assistance and in disseminating knowledge are Nordic organisations such as the Nordic Council of Ministers. The recommendations are more fully described below. 


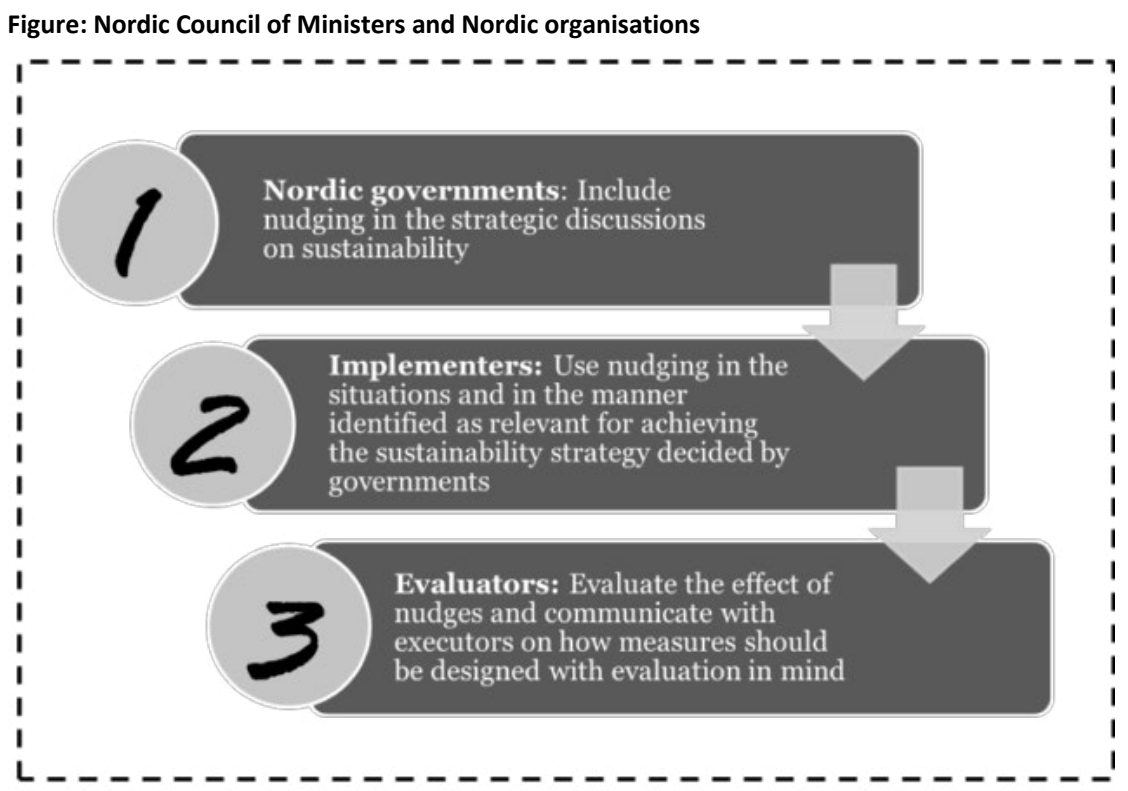

1. Nordic governments: The strategic debate on environmental and sustainability policy should include nudging as a potential tool. Strategies to enhance sustainable consumption should aim at solving the identified problems, and define how this can be done most effectively. Nudging can be an autonomous part of this, but it can also be part of a comprehensive policy package as a complement to other policy instruments, or to enhance the effect of these.

2. Implementers: Implementers of policy such as municipalities or government agencies should work with nudging to the extent that it fits into their overall mission. We have interviewed representatives mainly at the municipal level in Sweden, who are interested in using insights from behavioural economics, but who lack the knowledge of how they can do so. A general guide to nudging for increased sustainability could contribute to better understanding of and consensus on the benefits and challenges of nudging. Such a guide should contain clear steps -behavioural mapping, diagnosis and problem identification, solution/nudging design, evaluation and learning with practical examples that can help organisations who would like to work with nudging to do this in a structured way. 
3. Evaluators: It cannot be emphasised enough that knowledge about the effects that nudging is undeveloped, and that collecting data that enables evaluation and learning should be a central part of every nudging project. Nudging should be designed with evaluation in mind, and evaluating authorities in the Nordic countries should be commissioned to evaluate the effectiveness of interventions. To do so, evaluators will require knowledge of nudging. Feedback and learning also need to take place between implementers and evaluators. 


\section{Bilaga A - Beteenden relevanta för hållbar konsumtion av elektronik}

Tabell: Irrationella beteenden relevanta för hållbar konsumtion av elektronik

\begin{tabular}{|c|c|}
\hline Beteende & Beskrivning \\
\hline $\begin{array}{l}\text { Standard- } \\
\text { alternativ }\end{array}$ & $\begin{array}{l}\text { Människor tenderar att behålla status quo, välja standardalternativet eller skjuta upp } \\
\text { beslutsfattandet helt, särskilt när mängden och/eller komplexiteten av information } \\
\text { ökar. Till exempel tenderar människor att acceptera förvalda alternativ, även om } \\
\text { andra alternativ kan ge bättre utfall. Några anledningar till det är att vi ofta blir } \\
\text { överväldigade av information och har begränsat med tid och resurser, och därmed f } \\
\text { öredrar att inte ändra vårt beteende eller vanor om vi inte måste. Ett förvalt alternativ } \\
\text { kan också uppfattas som det bästa alternativet, eftersom det är "rekommenderat" av } \\
\text { en expert, exempelvis leverantören. }\end{array}$ \\
\hline "Sat & $\begin{array}{l}\text { Människor gör endast det som krävs för att uppnå ett tillfredsställande, snarare än ett } \\
\text { optimalt resultat; de nöjer sig med "tillräckligt bra" istället för "bäst". Det beror delvis } \\
\text { på att människor ofta är oförmögna att systematiskt bearbeta all tillgänglig } \\
\text { information när de översköljs av den, eller när den är alltför komplex. I dessa fall } \\
\text { tenderar man att välja det första tillgängliga alternativ som uppfyller minimikraven. } \\
\text { Tendensen, som kallas "satisficing" (av engelskans satisfy och suffice) underlättar } \\
\text { snabbare, mindre krävande informationsbehandling, problemlösning och } \\
\text { beslutsfattande, vilket är användbart vid många rutinmässiga handlingar. Satisficing } \\
\text { utövas dock också vid beslutssituationer av stor vikt, där en mer grundlig analys skulle } \\
\text { vara att föredra. }\end{array}$ \\
\hline
\end{tabular}

Förlust-

aversion

och

endowmen

t effect

Risk-

aversion

Människor är förlustaversa på så sätt att de väger förluster tyngre än stora vinster av motsvarande storlek, särskilt när insatserna ökar. När vi står inför att fatta ett beslut uppfattar vi kostnaden eller smärtan av att förlora något som större än nyttan av att få något likvärdigt. Resultat av ekonomiska experiment visar att människor värderar förluster mer än två gånger så högt som vinster. Tendensen illustreras också i studier av betalningsvilja där människor kan kräva upp till 20 gånger mer för att inte förlora något än vad de är villiga att betala för att få samma sak.

Människor har en aversion mot risker. Graden av riskaversion beror dock på vad som står på spel. Generellt är människor mer villiga att agera riskfyllt för att undvika en förlust än för att säkra en lika stor vinst. Människor är också generellt mer riskbenägna i situationer med små insatser än med stora, vilket kallas för "the peanut effect", dvs. människor är mer villiga att acceptera risker när enbart "peanuts" står på spel.

Sunk costs Att bli irrationellt fixerad på att återta resurser i form av exempelvis tid, arbete och fallacy pengar som tidigare investerats kallas ofta för "the sunk cost fallacy". Den kan leda til att människor fortsätter med ett beteende även när det blir väldigt riskfyllt, eller är otroligt att det ger önskat resultat. Vissa forskare menar att det beror på en övergeneralisering av "slösa inte"-regeln, det vill säga tanken att undvika svinn i allmänhet, som många har fått lära sig som barn. Att överge en tidigare investering kan därför göra att investeringen känns bortslösad. Till exempel tenderar konsumenter som lagt tid, möda och pengar på att köpa en elektrisk produkt (t.ex. luftkonditionering eller extra kylskåp) att använda den mer, även om det inte är optimalt.

\section{Källa}

Frederiks et al. (2015),

Johnson \& Goldstein

(2003)

Frederiks et al. (2015)

Frederiks et al. (2015), Tversky \& Kahneman (1992) och Mont et al. (2014)

Frederiks et al. (2015) Tversky \& Kahneman (1992)

Frederiks et al. (2015) 


\begin{tabular}{|c|c|c|}
\hline Beteende & ning & Källa \\
\hline ring & $\begin{array}{l}\text { Vi tenderar att uppfatta saker som mindre värdefulla eller betydande om de sker längre bort i } \\
\text { tiden (tidsmässig diskontering) eller längre bort geografiskt (rumslig diskontering). Det innebär } \\
\text { exempelvis att vi lägger mer vikt på de kortsiktiga konsekvenserna av våra beslut än de } \\
\text { långsiktiga. När det gäller konsumtion innebär det att konsumenter undviker åtgärder som är } \\
\text { kostsamma på kort sikt (t.ex. att lägga tid och pengar på att köpa nya energieffektiva apparater } \\
\text { eller anstränga sig för att byta elleverantör), trots att de skulle innebära långsiktiga vinster (t.ex. } \\
\text { minskade elräkningar). Det innebär också att människor tenderar att undervärdera de } \\
\text { långsiktiga effekterna av rökning, dålig kost, brist på motion och att skjuta upp } \\
\text { pensionssparandet, eftersom konsekvenserna är avlägsna. }\end{array}$ & $\begin{array}{l}\text { Frederiks et al. (2015), } \\
\text { Laibson (1997), Mont et } \\
\text { al. (2014) }\end{array}$ \\
\hline $\begin{array}{l}\text { Sociala } \\
\text { normer }\end{array}$ & $\begin{array}{l}\text { Människor gör sociala jämförelser, följer andras beteende, och anpassar sig till sociala } \\
\text { normer, det vill säga de explicita och implicita riktlinjer inom en grupp eller samhälle som } \\
\text { anses normala eller önskvärda. Det finns två typer av normer: föreskrivna normer och } \\
\text { deskriptiva normer. Föreskrivna normer innehåller en moralisk implikation, dvs. vad som } \\
\text { bör göras och vad som inte bör göras. Deskriptiva normer relaterar till hur andra beter sig, } \\
\text { det vill säga det "normala" sättet att göra något på. Normer syns bland annat i vår tendens } \\
\text { att" "följa med flocken" (flockbeteende) och "hoppa på tåget" (the bandwagon effect). } \\
\text { Människor tenderar också att göra sociala jämförelser och utvärdera sina egna } \\
\text { prestationer, ägodelar och välbefinnande i förhålllande till andra och inte i absoluta termer. }\end{array}$ & Frederiks et al. (2015) \\
\hline $\begin{array}{l}\text { Incitament } \\
\text { och } \\
\text { motivation }\end{array}$ & $\begin{array}{l}\text { Människor motiveras av belöningar och incitament, både inre motivation (t.ex. att } \\
\text { uppnå social rättvisa, eller att agera altruistiskt) och yttre motivation (t.ex. monetära). I } \\
\text { allmänhet ger större incitament eller hinder upphov till större beteendeförändringar. } \\
\text { Effekterna av ekonomiska incitament är dock ofta förvånansvärt kortlivade och/eller } \\
\text { ojämna, med beteende som kan återgå till ursprungsläget. Människor kan även svara } \\
\text { negativt på yttre belöningar, t.ex. uppvisa förlust av motivation. Om en person är } \\
\text { motiverad att vara altruistisk kan en monetär belöning för att uppmuntra önskat } \\
\text { beteende ha motsatt effekt och "tränga bort" den inre motivationen. }\end{array}$ & $\begin{array}{l}\text { Frederiks et al. (2015), } \\
\text { Mellström \& } \\
\text { Johannesson (2008) }\end{array}$ \\
\hline Free-riding & $\begin{array}{l}\text { Det är välkänt att åtminstone delar av en grupp människor ofta minskar sin } \\
\text { ansträngning, undanhåller resurser, eller bidrar mindre till den gemensamma nyttan } \\
\text { om de kan få samma förmåner utan att betala för dem, eller tror att andra åtnjuter } \\
\text { fördelar utan att bidra till den gemensamma nyttan (free-riding). De tenderar också att } \\
\text { anstränga sig mindre för att uppnå ett mål när de arbetar i grupp än när de arbetar } \\
\text { självständigt (social loafing), med lägre motivation ju mindre viktig den egna } \\
\text { ansträngningar är för gruppens framgång. }\end{array}$ & $\begin{array}{l}\text { Fischbacher et al. } \\
\text { (2001), Frederiks et al. } \\
\text { (2015) }\end{array}$ \\
\hline $\mathrm{F}$ & $\begin{array}{l}\text { Förtroende används ofta som en enkel tumregel för beslut vid risk- och } \\
\text { lönsamhetsbedömning, där trovärdighet beror på uppenbar kompetens och erfarenhet } \\
\text { (kompetensbaserat förtroende), samt upplevd öppenhet, ärlighet och omtanke om } \\
\text { andra (integritetsbaserat förtroende). Till exempel kan effekten av } \\
\text { informationskampanjer bero på den av mottagarna upplevda trovärdigheten av } \\
\text { kommunikationskällan. Om källan till ett meddelande verkar opålitlig, orättvis eller } \\
\text { inkompetent, kan människor agera försiktigt eller skeptiskt på information och } \\
\text { antingen ignorera den eller reagera defensivt. }\end{array}$ & Frederiks et al. (2015) \\
\hline $\begin{array}{l}\text { Tillgänglighe } \\
\text { tsskevhet } \\
\text { (availability } \\
\text { bias) }\end{array}$ & $\begin{array}{l}\text { Människor använder lättillgänglig information och information som ligger nära i minnet } \\
\text { oproportionerligt mycket. Det gör att vi tenderar att överskatta sannolikheten för } \\
\text { händelser som vi minns väl, eller som är särskilt frekventa, levande, framträdande, } \\
\text { känslomässiga eller konkreta i våra minnen. Det kan påverkas av hur nyligen något har } \\
\text { hänt eller hur känslomässigt laddad händelsen var och vem informationen kom från. } \\
\text { Vid tenderar därmed att ibland oroa oss alltför mycket för osannolika händelser, men } \\
\text { underskatta sannolikheten för troliga händelsen (kallas också för säkerhetseffekten). }\end{array}$ & $\begin{array}{l}\text { Frederiks et al. (2015), } \\
\text { Kahneman (2011), } \\
\text { Mont et al. (2014) }\end{array}$ \\
\hline
\end{tabular}




\begin{tabular}{lll} 
Beteende & Beskrivning & Källa \\
\hline $\begin{array}{l}\text { Kognitiv } \\
\text { konsekvens }\end{array}$ & $\begin{array}{l}\text { Individer tenderar att söka överensstämmelse mellan vad de tror och hur de beter sig. } \\
\text { När tron och beteendet inte stämmer överens uppstår så kallad kognitiv dissonans. För } \\
\text { att undvika kognitiv dissonans måste något ändras, och det lättaste är oftast att ändra } \\
\text { sin tro istället för sitt beteende. Det gör att förändringar från irrationellt beteende till } \\
\text { rationellt beteende kan vara svåra att genomföra. }\end{array}$ & Mont et al. (2014) \\
\hline $\begin{array}{ll}\text { Identifikatio } \\
\mathrm{n}\end{array}$ & $\begin{array}{l}\text { Människor tenderar att identifiera sig med en viss grupp, uttrycka lojalitet och skaffa } \\
\text { sig en identitet förknippad med vissa sociala grupperingar, oavsett om det är } \\
\text { samhällsgrupp, en grupp kollegor eller en grupp vänner. Människor som tillhör en viss } \\
\text { grupp tenderar att efterlikna beteendet hos medlemmarna i gruppen. }\end{array}$ & Mont et al. (2014) \\
\hline
\end{tabular}




\section{Bilaga B - Intervjuer, praktiska insikter om beteendeekonomi och elektronikkonsumtion}

Generella intervjufrågor

(anpassat efter intervjuperson)

- Vad tror du är det största hindret för hållbar konsumtion av elektronikprodukter?

- Var, i kedjan från köpbeslut till kasserad produkt, ligger hindren? Vid köp, återanvändning, återvinning, eller någon annanstans?

- Var tror du den största förbättringspotentialen finns, hos konsumenter eller producenter?

- Hur kan vi använda det vi vet om konsumenters beteenden (generellt och specifikt vid köp av elektronikprodukter) för att få konsumenter att överkomma hinder för hållbar konsumtion?

- Har du några bra exempel på hur insikter från beteendevetenskap använts, till exempel för att förändra konsumtion, som kan appliceras på konsumtion av elektronikprodukter?

- Har du övriga idéer på hur man kan påverka konsumtion av elektronikprodukter i en mer hållbar riktning? 


\section{Bilaga C - Frågeformulär i} pilotstudie av nudging för hållbar mobiltelefonkonsumtion hos unga

\section{Förstudie}

För att få det underlag som behövs för beteendekartläggningen genomfördes inledningsvis 26 personliga intervjuer i en 3-butik bland ungdomar som köpt eller varit intresserade av att köpa en mobil. Intervjuerna skedde under maj månad i Danmark.

Följande frågor ställdes:

- Alder:

- Køn:

1. Har du for nylig købt en ny mobiltelefon?

- Ja, i dag.

- Ja, inden for den sidste måned.

- Nej, det er længere tid siden end en måned.

2. Hvad fik dig til at købe din nye mobiltelefon? (Sæt meget gerne flere krydser).

- Den gamle blev stjålet.

- Den gamle var i stykker.

- Den gamle fungerede ikke godt nok (langsom, kunne ikke køre programmer, dårlig batterilevetid, osv.).

- Jeg fik en ny af f.eks. venner, familie eller arbejde.

- Der var en god pris på den nye mobil.

- Der var en god pris på et nyt abonnement eller mit gamle abonnement var dyrt.

- Jeg ville bare hellere have den nye.

- Andet: 
Besvar venligst kunne dette spørgsmål hvis du besvarede forgående spørgsmål med 2 eller 3.

3. Hvad var i stykker eller fungerede ikke ved din gamle mobil:

- Tastaturet virkede ikke.

- Batterilevetiden var for kort.

- Skærmen (fx fordi den blev tabt).

- Noget teknisk/mekanisk internt i mobilen (generel langsom, den opførte sig forkert, osv.).

- Andet:

4. Undersøgte du om du kunne få din gamle mobil repareret inden du fik din nye?

- Ja, men det var for dyrt.

- Ja, men det var for besværligt.

- Ja, jeg fik den til reparation, men det virkede ikke.

- Nej, det undersøgte jeg ikke.

5. Hvor vigtige var følgende faktorer i din beslutningsproces for købet af din nye mobil? Meget vigtigt/Vigtigt/Ikke så vigtigt/Ved ikke.

Besvar gerne selvom du ikke har købt den i dag. Sæt venligst kun et X.

- Mærke/Model (F.eks. iPhone 6 eller Samsung Galaxy S6).

- Lav pris på mobilen (udgiften i butikken).

- Lav pris på abonnementet (Billig data, telefoni, SMS).

- Fordelagtig afbetalingsordninger. 


\section{Enkätundersökning}

Baserat på informationen i intervjuerna utarbetades en enkät, som skickades till ca 440 personer i Danmark och Sverige i juni och juli månad 2015. Frågorna skickades ut på danska till personer i Danmark, och på engelska till personer i Sverige.

Följande frågor ställdes:

1. How old are you?

2. What is your gender?

Are you currently enrolled in education?

3. If yes: Which education?

- Primary school or high school.

- Vocational education.

- Short- or medium course higher education.

- Long course higher education.

4. If no: What is your highest completed education?

- Primary school or high school.

- Vocational education.

- Short- or medium course higher education.

- Long course higher education.

5. Do you have a mobile phone?

- Yes.

- No.

6. Have you had any other mobile phones before your current one?

- Yes.

- No.

7. When did you get your current mobile phone? (indicate approx. year if you cannot remember).

- [Enter year]. 
8. Why did you get your current mobile phone? (Please feel free to fill in several fields).

- The old one got stolen.

- The old one broke.

- The old one did not work well enough (slow, could not run programs, poor battery life, etc.).

- I got a new one of my parents, family, friends or job.

- There was a good price on the new mobile phone.

- There was a good price on a new subscription or my old subscription was expensive.

- The seller had me convinced that it was a good idea.

- I just wanted a new one.

- Other? Please comment.

9. What was broken or did not work on your old mobile phone? (ONLY ANSWER IF RELEVANT).

- Not relevant.

- The keyboard did not work.

- The battery life was too short.

- The screen (e.g. because it was dropped).

- Some technical/mechanical internally in the phone (general slow, it behaved incorrectly, etc.).

- Other? Please comment.

10. Did you check if you could get your old phone repaired before you got your new? (ONLY ANSWER IF RELEVANT).

- Not relevant.

- Yes, but it was too expensive.

- Yes, but it was too difficult.

- Yes, I got it repaired but it did not work.

- No, I did not check that.

- Other? Please comment. 
11. How important were the following factors in your decision making process for the purchase of your mobile phone?

- The particular brand or model (e.g. iPhone 6 or Samsung Galaxy).

- Low price on the phone (the cost in the store).

- Low price of the subscription (cheap data, telephony and texting).

- Advantageous credit programs.

- Environmental consequences of the choice of mobile phone.

12. Do you expect to get a new mobile phone in the near future?

- Yes, within the next few months.

- Yes, within six months.

- No, it will be more than half a year before I expect to have a new one.

13. What do you expect will be the reasons for you to buy your next mobile phone? (ONLY ANSWER IF RELEVANT) Please feel free to fill in several fields.

- My current mobile phone will be stolen.

- My current mobile phone will break.

- My current is not working well enough (slow, cannot run programs, poor battery life, etc.).

- I get a new one of my parents, family, friends or job.

- There is a good price on the new mobile phone.

- There is a good price on a new subscription or my current subscription is too expensive.

- I will just want a new one.

- Other? Please comment.

14. What do you expect breaks or not work on your current mobile phone, so that you in the future will need a new one? (ONLY ANSWER IF RELEVANT).

- The keyboard does not work.

- The battery life is too short.

- The screen (e.g. because it was dropped).

- Some technical/mechanical internally in the phone (general slow, behaving incorrectly, etc.).

- Other? Please comment. 
15. How many mobile phones do you own in total?

$-0$.

-1 .

-2 .

$-3$.

-4 .

-5 .

- More.

16. Think of a specific mobile phone you own, which is not the one you use now. What is the reason that you still have it? ONLY ANSWER IF YOU HAVE MORE THAN ONE MOBILE PHONE.

- It has personal pictures, messages, music, etc. on it, which I would like to store or transfer one day.

- It is nice to have an extra mobile phone in case if the current mobile phone breaks.

- The price of selling it is not high enough.

- I do not know where to put it.

- It is just not important, I have not thought about where to put it.

- Other? Please comment.

Imagine that you can rent your mobile phone so that you pay a monthly fee to have the service from your phone instead of owning it. Therefore, you can return it if you do not want it any longer or if you would rather rent another mobile phone.

Imagine the next time you need a new phone; you can either buy it or rent it. In either case, the mobile phone and the amount you pay is identical.

17. How important is it for you to own the mobile phone instead of possibly renting it?

- Very important.

- Important.

- Not so important.

- Does not matter. 
18. Imagine that you rent your next mobile phone. How much would you appreciate the following options? Rank from most to least important:

- If my rented mobile phone breaks I am guaranteed a new and identical mobile phone immediately.

- It is possible to transfer data, images and other things from one phone to another when I rent a new one.

- It is possible to transfer data, images and other things from one mobile phone to a USB connector when I rent a new one.

Imagine a deposit-refund system for mobile phones is introduced. This means that the next time you buy a new mobile phone it will cost e.g. DKK 200 more. In return, you get DKK 200 when you hand over your phone in the store after use.

19. How much would you, as a minimum, put in deposit in order to be willing go back in the shop and withdraw the deposit after use (instead of, alternatively, keeping the mobile phone or selling it)?

- DKK 50.

- DKK 100.

- $\quad$ DKK 200.

- DKK 300.

- DKK 400.

- DKK 500.

- DKK 600.

- DKK 800.

- DKK 1000.

- More than DKK 1000.

20. Which model would you prefer for your next mobile phone purchase? Rank from most to least preferred:

- The current system (I buy my mobile phone and I own it).

- The leasing model (I rent my mobile phone and I am guaranteed service).

- The deposit model (I buy my mobile phone and pay the deposit, which I will get back). 
21. How important is the environment when you buy a mobile phone?

- Not important.

- I was not aware of the fact that there are environmental friendly mobile phones.

- That means little, but I will not pay more for the environment alone.

- It means something and I want to pay more for environmental friendly mobile phones.

Fråga 22 sändes ut i två versioner. Somliga respondenter fick besvara fråga 22a och somliga fråga $22 b$.

22a. Would you buy an environmental friendly mobile phone if there was a DKK 200 discount on environmentally friendly mobile phones?

- Yes, definitely.

- Yes, maybe.

- No, probably not.

- Definitely no.

- Do not know.

22b. Would you buy an environmental friendly mobile phone, if non-environmental friendly mobile phones cost DKK 200 more due to an environmental tax?

- Yes, definitely.

- Yes, maybe.

- No, probably not.

- Definitely no.

- Do not know. 


\section{Bilaga D - Resultat i pilotstudie av nudging för hållbar mobil- telefonkonsumtion bland unga}

Bland de som svarade att de köpt sin nuvarande mobiltelefon på grund av att den förra var sönder eller inte fungerade som den skulle, var huvudorsaken till att den förra mobiltelefonens inte fungerade ett tekniskt/mekaniskt fel. Vidare svarade $39 \%$ av respondenterna att batteritiden var för kort, se Figur 21.

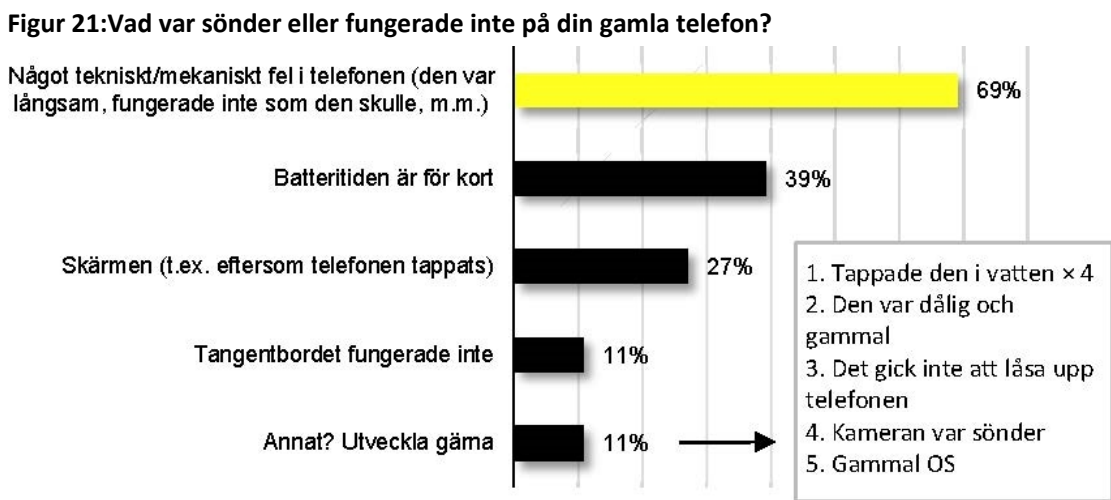

Not: Respondenten kan ange flera svarsalternativ. I rutan anges de anledningar som de som svarade "annat" angav. $\times 4$ innebär att det var fyra personer som gav samma anledning. I de fall där respondenten svarade "annat" och gav en anledning som var direkt kopplad till något av de övriga svarsalternativen, har detta sorterats in i respektive svarsalternativ

Källa: Copenhagen Economics.

$76 \%$ av respondenterna uppskattar att det kommer dröja mer än ett halvår innan de äger en ny mobiltelefon. Vidare uppskattar $12 \%$ att de kommer äga en ny telefon inom de närmsta månaderna, se Figur 22. 
Figur 22: Förväntar du dig att du kommer äga en ny telefon inom den närmsta framtiden?

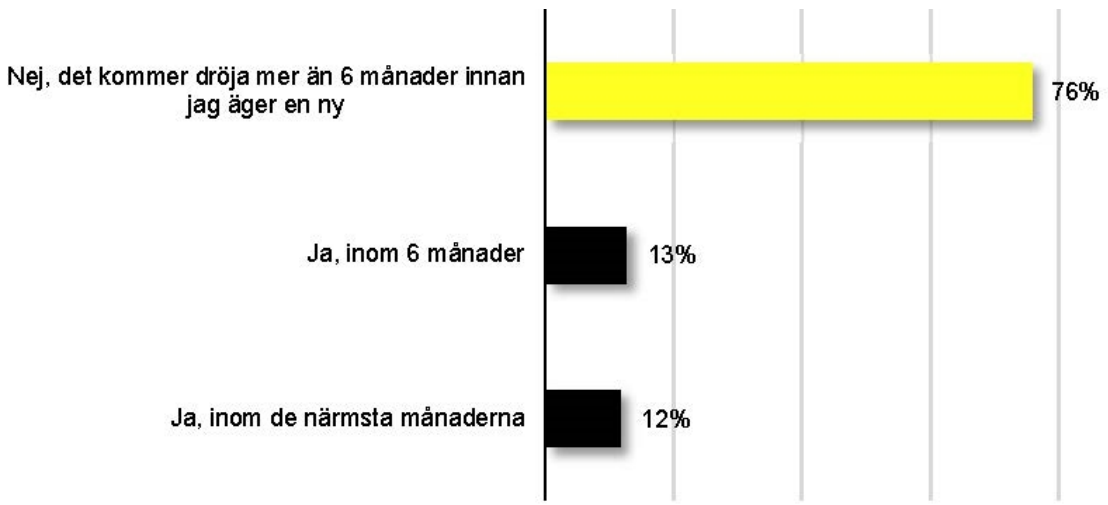

Källa: Copenhagen Economics.

Den förväntade anledningen till varför majoriteten av respondenterna kommer köpa en ny mobiltelefon är på grund av att den nuvarande inte fungerar bra nog följt av att den nuvarande telefonen förväntas gå sönder, se Figur 23. Vidare förväntar sig betydligt färre att ett bra pris på en ny mobiltelefon eller ett abonnemang kommer vara den främsta anledningen till varför man kommer köpa en ny mobiltelefon.

Figur 23: Vad förväntar du dig kommer vara anledningen till att du köper en ny telefon?

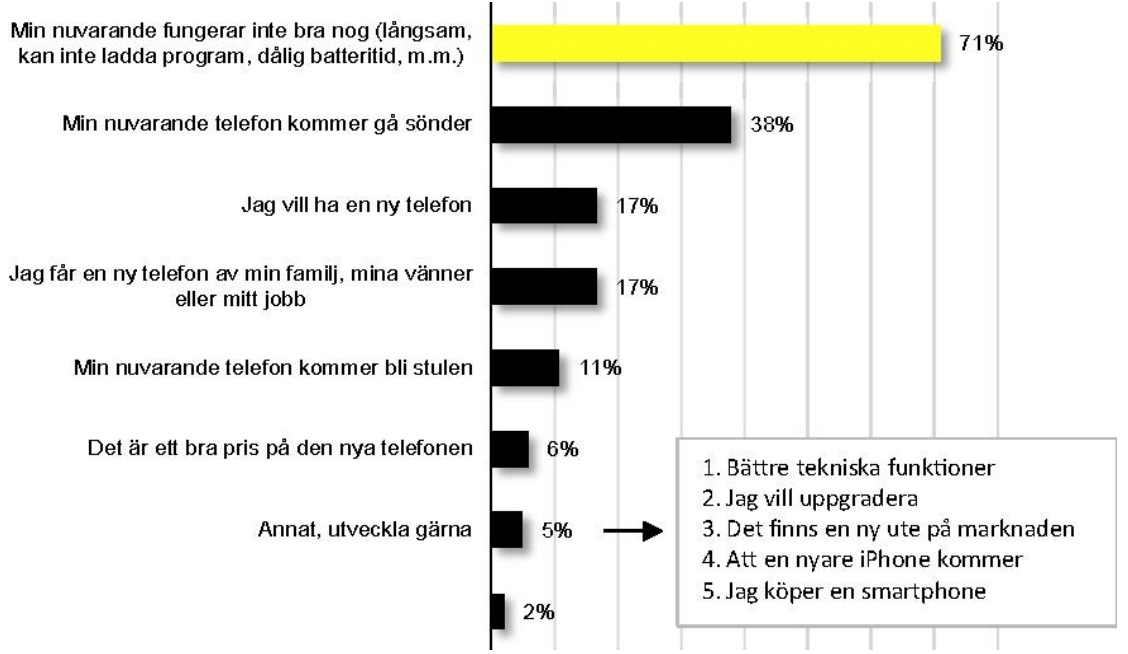

Not: Respondenten kan ange flera svarsalternativ. I rutan anges de anledningar som de som svarade "annat" angav.

Källa: Copenhagen Economics. 
Den främsta anledningen till att respondenterna tror sig kommer behöva köpa en ny telefon $\mathrm{i}$ framtiden tros vara på grund av ett tekniskt/mekaniskt fel, se Figur 24. Detta kan jämföras med Figur 9, där främsta anledningen till varför respondenterna köpte sin nuvarande telefon var på grund av just detta. Förväntan tycks därmed stämma överens med tidigare erfarenheter.

Figur 24: Vad förväntar du dig kommer gå sönder eller kommer sluta fungera på din nuvarande mobiltelefon, så att du i framtiden kommer behöva en ny?

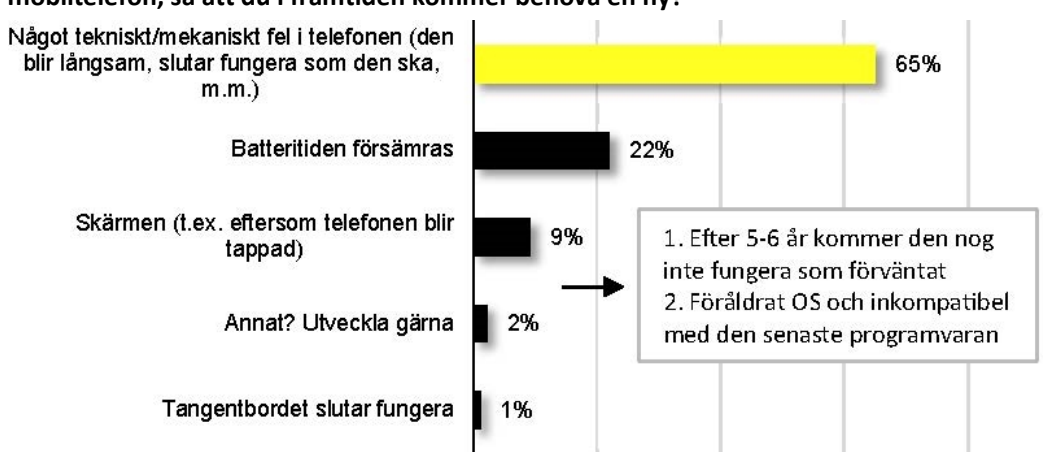

Källa: Copenhagen Economics.

\section{Återvinning/återlämning av mobiltelefoner}

49 \% av respondenterna äger en mobil medan drygt en fjärdedel äger två mobiler, se Figur 25. Det totala antalet mobiltelefoner bland de 101 som svarade på denna fråga är minst 207 stycken (de som angav fler än fem behövde inte specificera antalet).

Figur 25: Hur många telefoner äger du totalt?

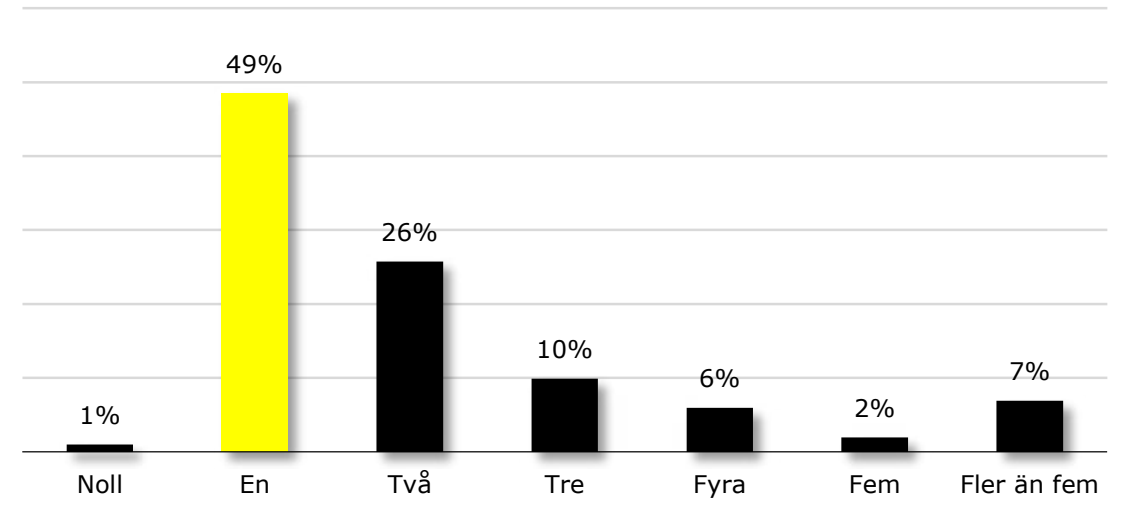

Källa: Copenhagen Economics. 
$97 \%$ av respondenterna tycker det är mycket viktigt eller viktigt att man är garanterad en identisk telefon direkt, om den hyrda telefonen går sönder och $92 \%$ anser att ha möjligheten att överföra bilder etc. från en hyrd telefon till en annan hyrd telefon är mycket viktigt eller viktigt, se Figur 26.

Figur 26: Föreställ dig att du hyr din nästa telefon. Hur mycket skulle du uppskatta följande alternativ?

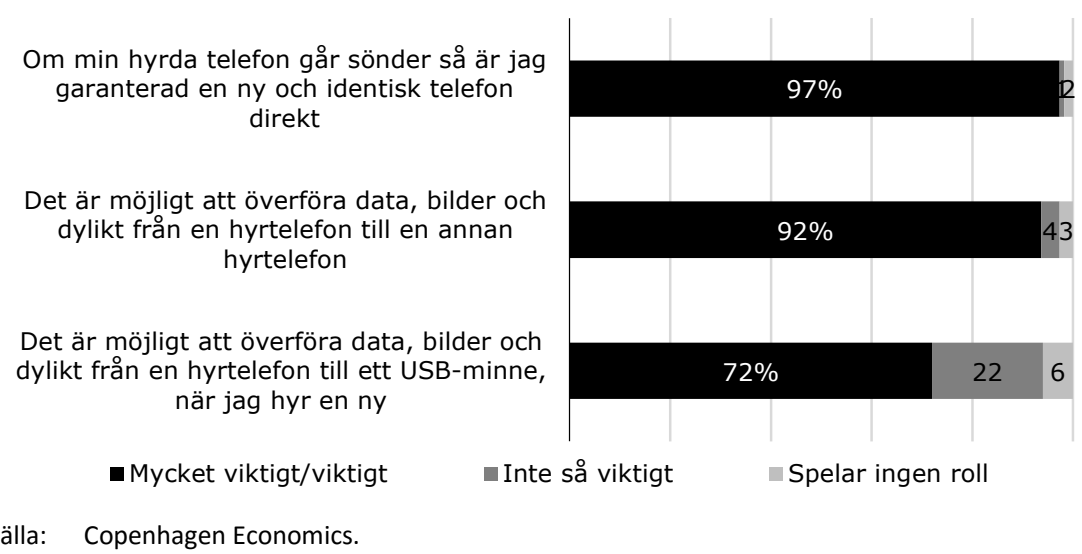

En klar majoritet (67\%) av de svarande anser att det nuvarande systemet, där man själv äger sin mobiltelefon, är det främsta. Respondenterna föredrar även leasingmodellen framför pantmodellen då $48 \%$ har placerat leasingmodellen på andra plats och $56 \%$ har placerat pantmodellen på tredjeplats, se Figur 27.

Figur 27: Vilken modell skulle du föredra inför ditt nästa köp av mobiltelefon? Rangordna alternativen

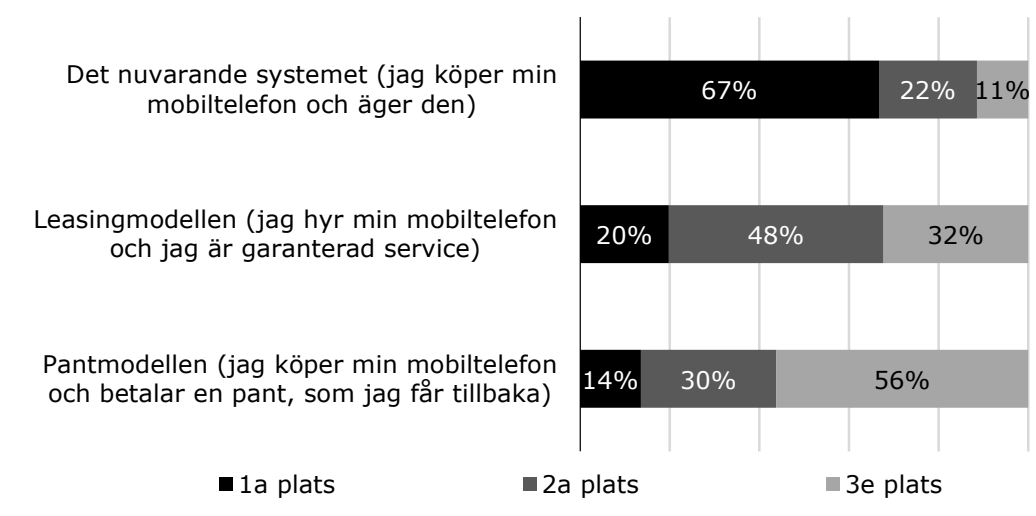

Källa: Copenhagen Economics. 
$78 \%$ av respondenterna tänkte inte på miljökonsekvenserna vid valet av sin nuvarande mobiltelefon, se Figur 28. Endast $4 \%$ sa sig tycka att miljökonsekvenser av mobiltelefon var viktigt eller mycket viktigt. Märket/modellen samt priset på abonnemanget ligger högt upp på listan, men det är även viktigt att själva mobiltelefonen har ett lågt pris.

Figur 28: Hur viktiga var följande faktorer under din beslutsprocess för inköp av din nyaste mobiltelefon? (\%)

Själva märket eller modellen (t.ex. iPhone 6 eller Samsung Galaxy)

Lågt pris på abonnemanget (billig data, samtals- eller smskostnad)

70

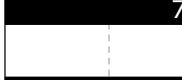

25

Lågt pris på telefonen (priset i affären)

Fördelaktiga kreditprogram

Miljökonsekvenser av valet av mobiltelefon

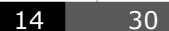

69

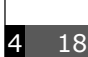
78

Mycket viktigt + viktigt

- Inte så viktigt

Jag tänkte inte på det

Källa: Copenhagen Economics. 


\section{Bilaga E-Experiment 1, version 1: ny mobil eller skärmreparation}

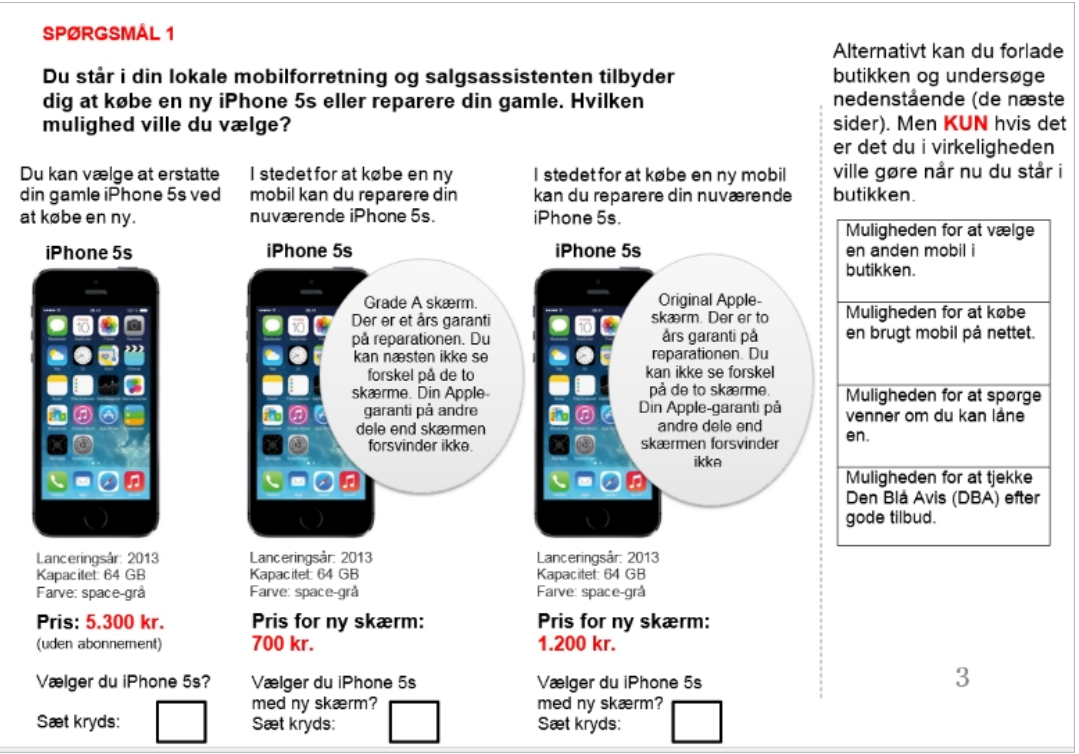




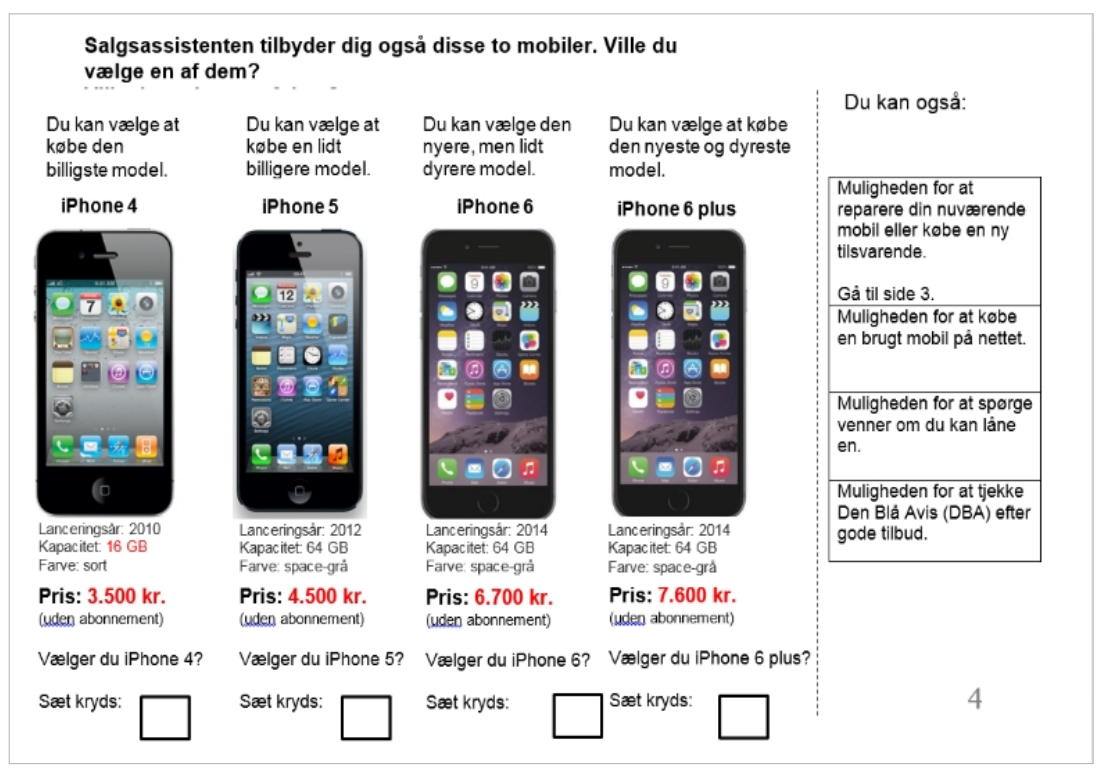

Du går ind på hjemmesiden www.bruqteiphones.dk. Her kan du købe følgende to mobiler. Ville du vælge en af dem?

Du kan ogsá:

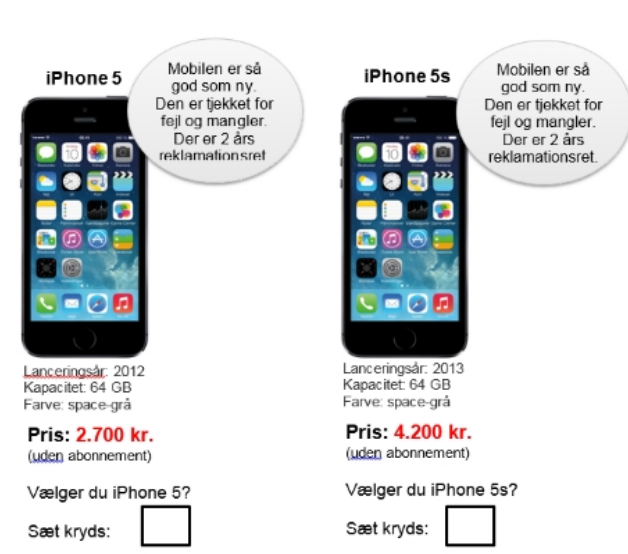

Muligheden for at reparere din nuværende tilsvarende.

Gả til side 3. Muligheden for at væelge en anden mobil i

Muligheden for at sporge venner om du kan lâne

Muligheden for at tjekke Den Bla Avis (DBA) efter gode tilbud.

Sæt kryds: 


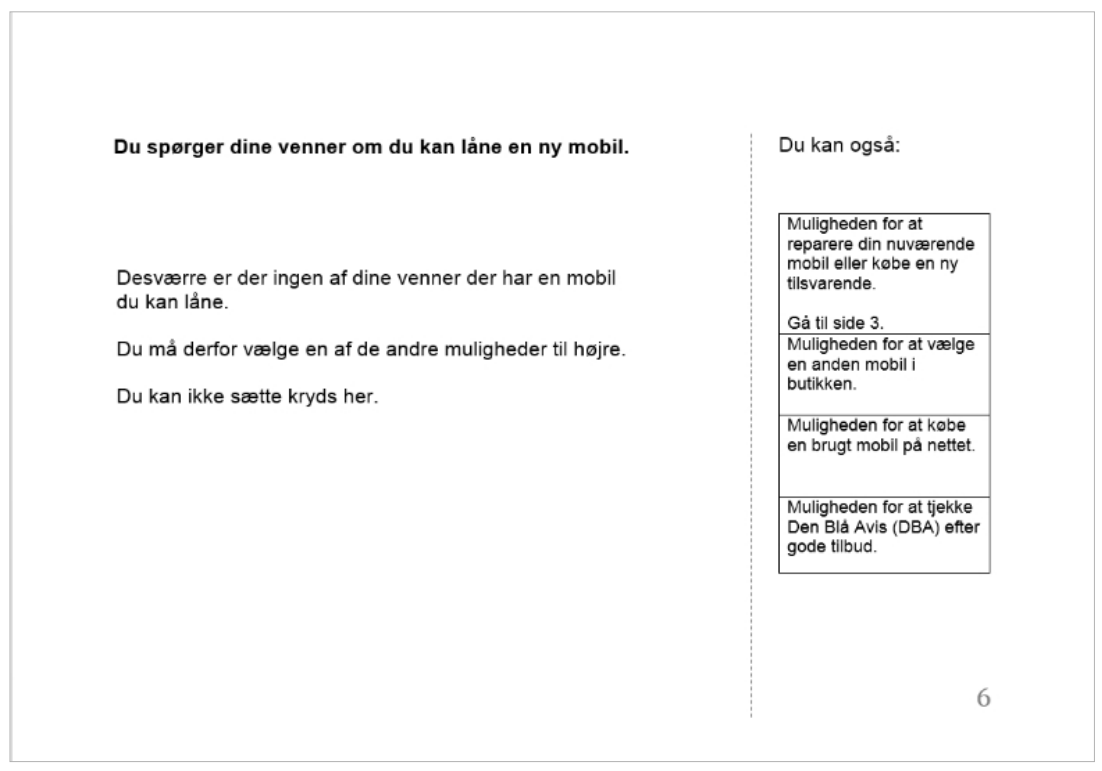

Du tjekker Den Blå Avis (DBA) efter gode tilbud.

Du kan også:

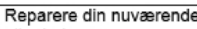
eller kobe en ny

tilsvarende

Desværre er der ingen gode tilbud i Den Blå Avis.

Gá til side 3.

Muligheden for at vælge

en anden mobil $i$

butikken

Du må derfor vælge en af de andre muligheder til højre.

Muligheden for at købe en brugt mobil pá nettes.

Du kan ikke sætte kryds her.

Muligheden for at sperge

venner om du kan lâne
en. 


\section{Bilaga F - Experiment 1,}

version 2: ny eller

begagnad mobil

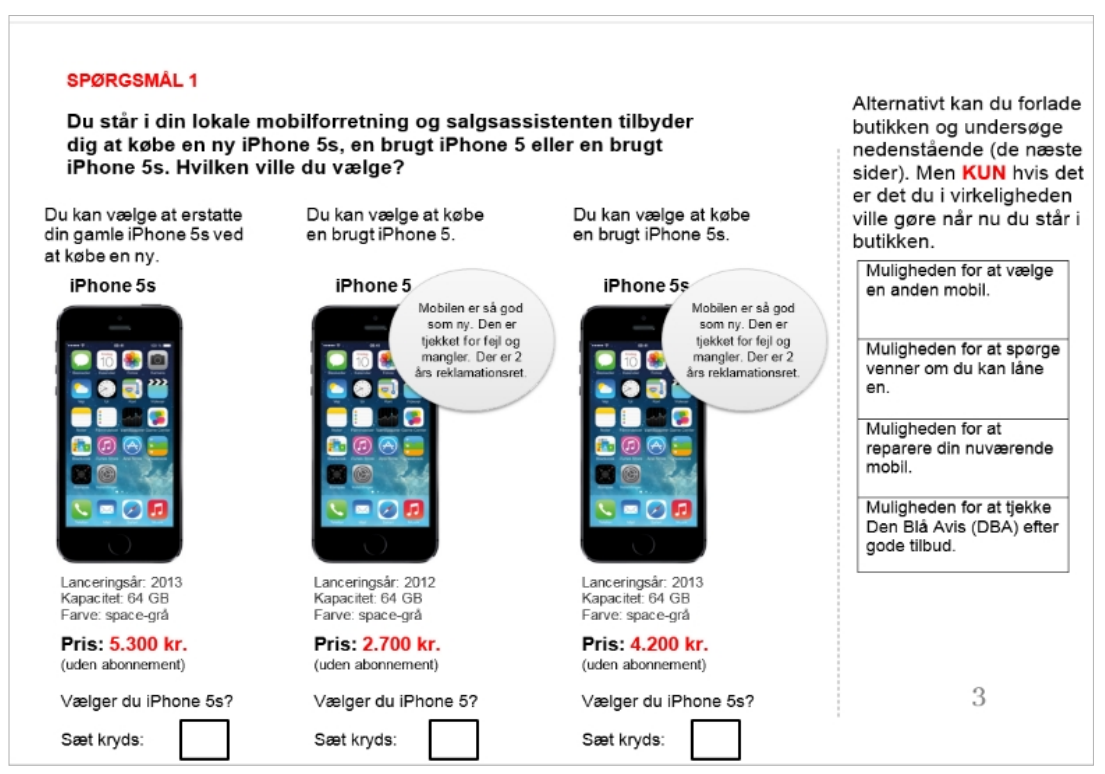




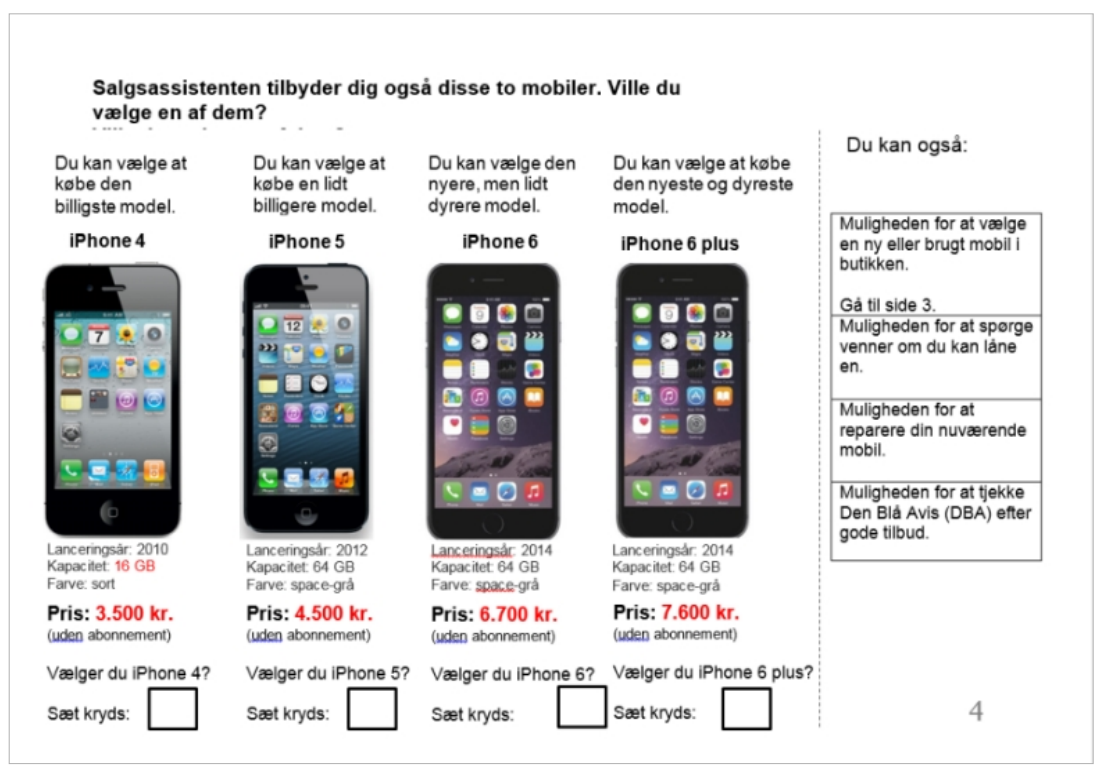

Du sperger dine venner om du kan làne en ny mobil.

Desværre er der ingen af dine venner der har en mobil du kan läne.

Du má derfor vælge en af de andre muligheder til højre.

Du kan ikke sæotte kryds her.
Du kan ogsâ: Mullgheden for at veige
en ny eller brugt mobili butikken.

Gat tll gide 3.

Mullgheden for at velge en anden mobil 1

butikken

Mullgheden for at reperere din nuvverende repere
mobil.

Muligheden for at tjekke Den Blà Avis (DBA) efter gode tilbud. 
Du găr til en reparatør som tilbyder at sætte en ny skærm pá

Du kan ogsä:

din nuverende mobii. Du kan vape mellem original kvalitet

Ville du yælge en af dem?

stedet for at købe en ny mobi kan du reparere din nuvøren

Phone 5s.

iPhone 5s

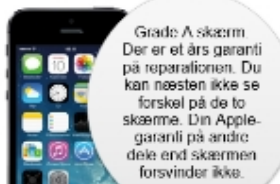

1000

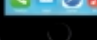

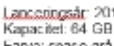

Panc sacenst

Pris for ny skærm

$700 \mathrm{kr}$.

Vaiger du IPhone 5s

Ssot kryds:

I stedet for at kabe en ny mobi iPhone $5 \mathrm{~s}$

iPhone 5s

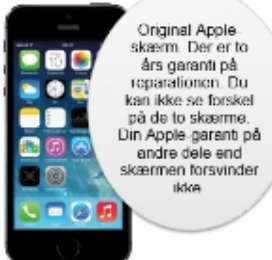

heden for at vesige en ny eller brugt mobil I

Gát til side 3.

Muligheden for at veilge

butikken

Muligheden for at sperge

Muligheden for at tjekke gode tllbud

Kapachat 64 , $6 \mathrm{~B}$

Pris for ny skærm

$1.200 \mathrm{kr}$.

Vøelger du iPhone 5s

Du tjekker Den Blå Avis (DBA) efter gode tilbud.

Du kan også:

Desværre er der ingen gode tilbud i Den Blå Avis.

ny eller brugt mobil i butikken.

Gá til side 3.

Muligheden for at vælge en anden mobil

Du má derfor vælge en af de andre muligheder til højre.

Du kan ikke sætte kryds her.

Muligheden for at sperg venner om du kan lảne en.

Muligheden for at

reparere din nuværend

mobil. 


\section{Bilaga G - Experiment 1, version 3: enbart ny mobil (referensscenario)}

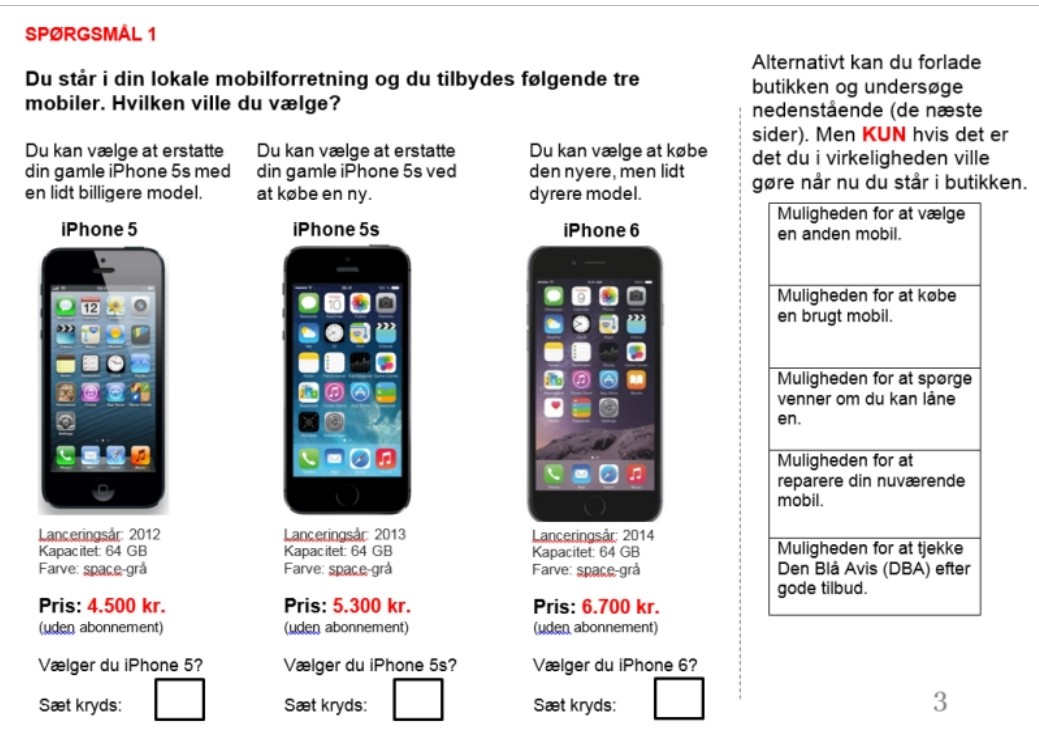


Salgsassistenten tilbyder dig også disse to mobiler. Ville du vælge en af dem?

Du kan også:

$\begin{array}{ll}\text { Du kan vælge at erstatte din } & \text { Du kan vælge at erstatte din } \\ \text { gamle iPhone } 5 \text { s med en } & \text { gamle iPhone } 5 \text { m med den } \\ \text { endnu billigere model } & \text { nyeste og dyreste model. }\end{array}$

endnu billigere model. nyeste og dyreste mode.

iPhone 4

iPhone 6 plus

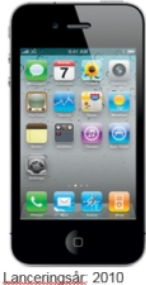

으뭉

을을를

즁후으음

붕응

ins

100

Kapacinet $16 \mathrm{~GB}$

Lanceringsid 2014

Pris: $3.500 \mathrm{kr}$.
(uden abonnement)

Pris: $7.600 \mathrm{kr}$.
(uden abonnement)

Vælger du iPhone 4?

Vøiger du iPhone 6 plus?

Sæt kryds:

Sæt kryds:

Muligheden for at kobe

Gá til side 3.

Muligheden for at kobe en brugt mobi

Muligheden for at sporge venner om du kan läne en.

Muligheden for at reparere din nuværende mobil.

Muligheden for at tjekke Den Blá Avis (DBA) effer gode tilbud.
Du gàr ind pả hjemmesiden www.brugteiphones.dk. Her kan du købe følgende to mobiler. Ville du vælge en af dem?

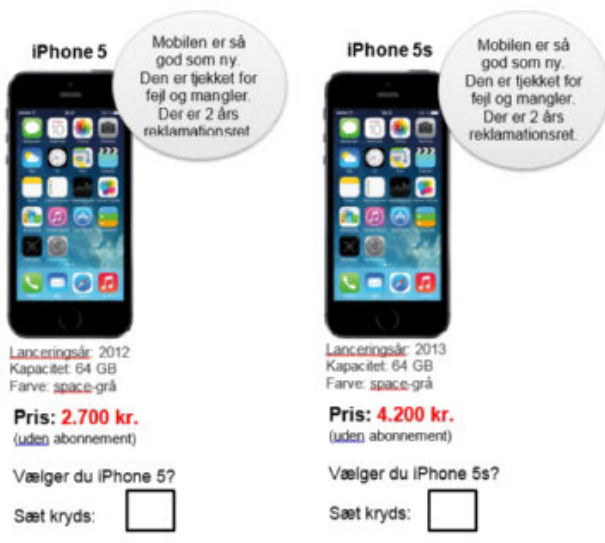

Du kan også:

Muligheden for at kobe en ny mobil I butikken.

Gá til side 3.

Muligheden for at vaige en anden mobill i

butikken.

Mulligheden for at sporge Muigheden for at sporge venner om du ka Muligheden for a: eparere din nuvæerende mobil.

Muligheden for at tjekke Den Bla Avis (DBA) efter gode tilibud.

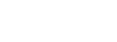


Du sperger dine venner om du kan láne en ny mobil.

Desværre er der ingen af dine venner der har en mobil du kan làne.

Du má derfor væige en af de andre muligheder til højre.

Du kan ikke sætte kryds her.
Du kan ogsâ:

\section{Muligheden for at kobe}

Ge till side 3 .

Muligheden for at væeige en anden mobil i

butikken.

Muligheden for at kobe en brugt mobil.

Muligheden for at

din nuvwerende

mobil.

Muligheden for at tjekke Den Blà Avis (DBA) efter gode tilbud.
Du gár til en reparater som tilbyder at sætte en ny skærm pá din nuværende mobil. Du kan vælge mellem original kvalitet
(dvs. kun Apple-reservedele) eller en billigere grade A skærm. Ville du vælge en af dem?

stedetfor at kobe en ny mobi kan du reparere din nuværende iPhone 5s.

iPhone 5s

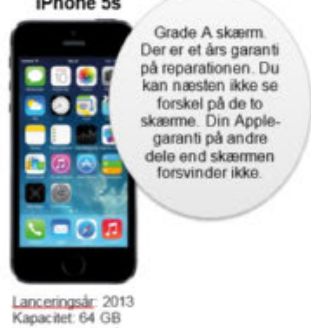

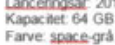

Pris for ny skærm:

$700 \mathrm{kr}$.

Voeiger du IPhone 5s med ny skæerm?

Sort kryds:
I stedet for at kobe en ny mobil kan du reparere din nuvarend iPhone 5s.

IPhone 5s

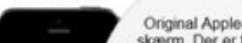

c日e

- 0 อ.

ancer pá de to skmarme.

Q

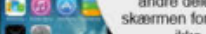

LOOB

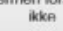

Lancerinosic 201

Farve: space-gra

Pris for ny skærm:

$1.200 \mathrm{kr}$.

Væiger du iPhone 5s

med ny skærm?
Du kan ogsá:

Muligheden for at kobe

en ny mobil i butikken.

Gá til side 3.

Muligheden for at vailge en anden mobili $i$

butikken. Muligheden for at kobe
en brugt mobil.

Muligheden for at sporge venner om du kan läne en.

Muligheden for at tjekke Den Blà Avis (DBA) efter gode tilibud. 


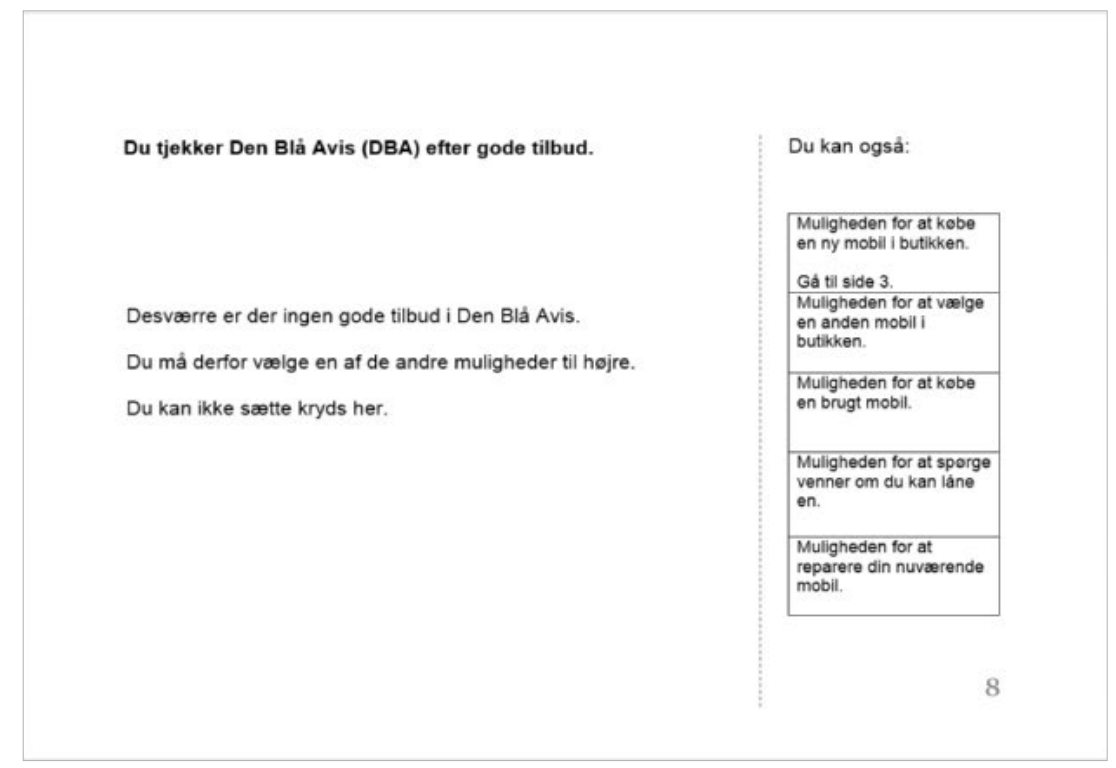




\section{Bilaga $\mathrm{H}$ - Experiment 2, version 1: med och utan hyr-nudge}

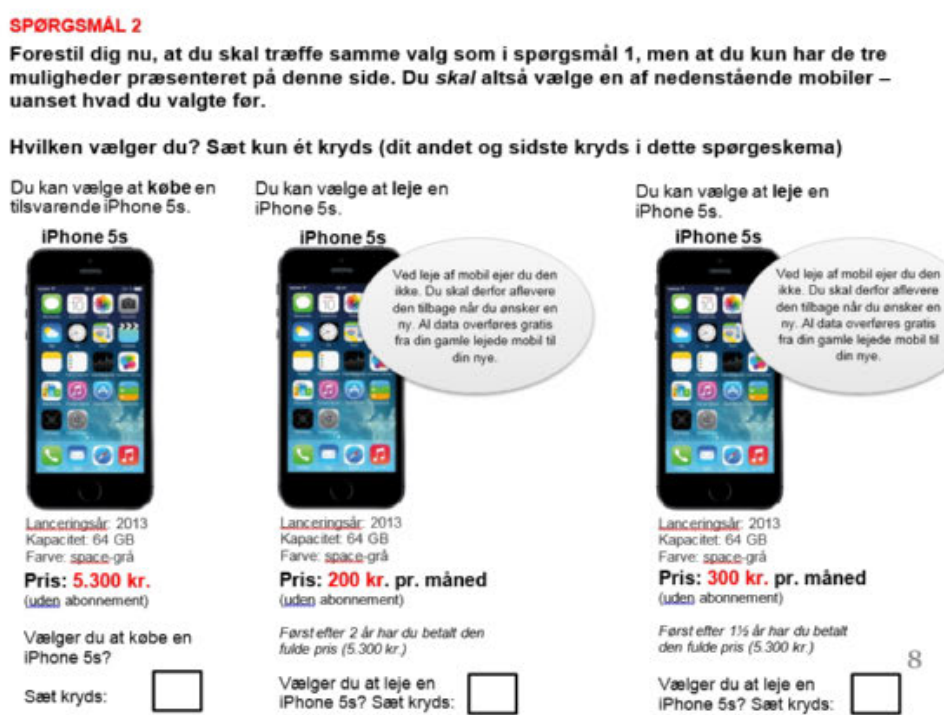


SPøRGSMÁL 2

Forestil dig nu, at du skal træffe samme valg som i spørgsmål 1, men at du kun har de to

muligheder præsenteret på denne side. Du skal altså vælge en af nedenstående mobiler -

uanset hvad du valgte før.

Hvilken vælger du? Sæt kun ét kryds (dit andet og sidste kryds i dette spørgeskema)

Du kan vælge at købe en
tilsvarende iPhone $5 \mathrm{~s}$. Du kan vælge at leje en
iPhone $5 \mathrm{~s}$.

iPhone 5s

iPhone 5s

อิํํํำ

을르"

무을

중 산

4008

Lanceringsår: 2013
Kapacitet. $64 \mathrm{~GB}$

Pris: $5.300 \mathrm{kr}$.

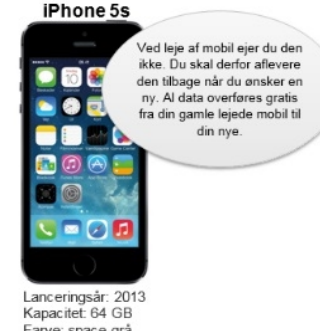

Kapacitet $64 \mathrm{~GB}$
Farve: space-grad

Pris: 200 kr. pr. måned

Vælger du at købe en
IPhone 5s?

Forstefter 2 àr har du betalt den
fulde pris (5.300 kr.)

Sæt kryds:

Vælger du at leje en
iPhone 5 s? Sæt kryds: 


\section{Bilaga I - Experiment 2, version 2: med och utan grön nudge}

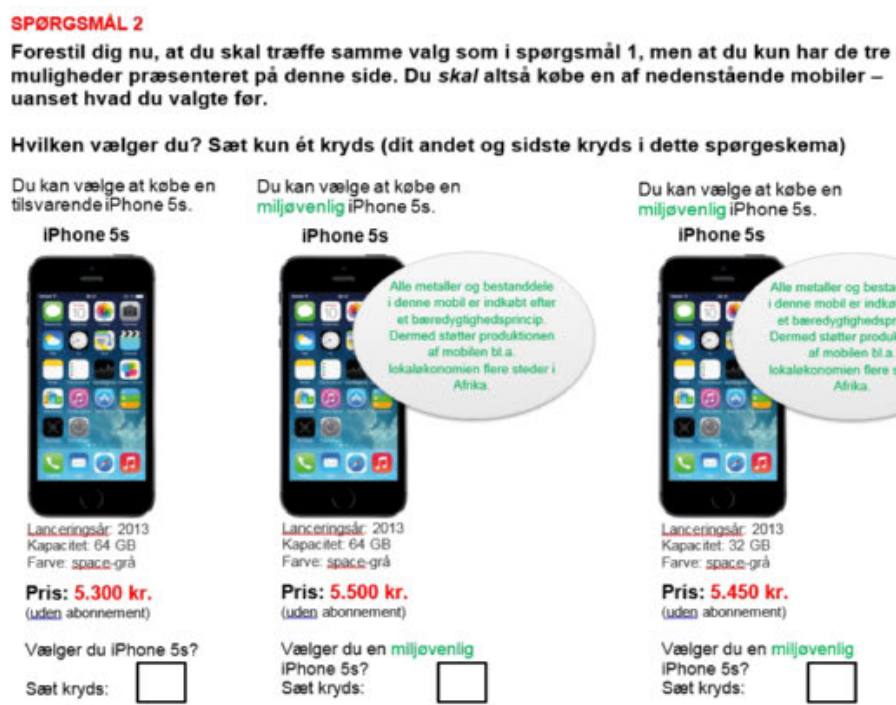




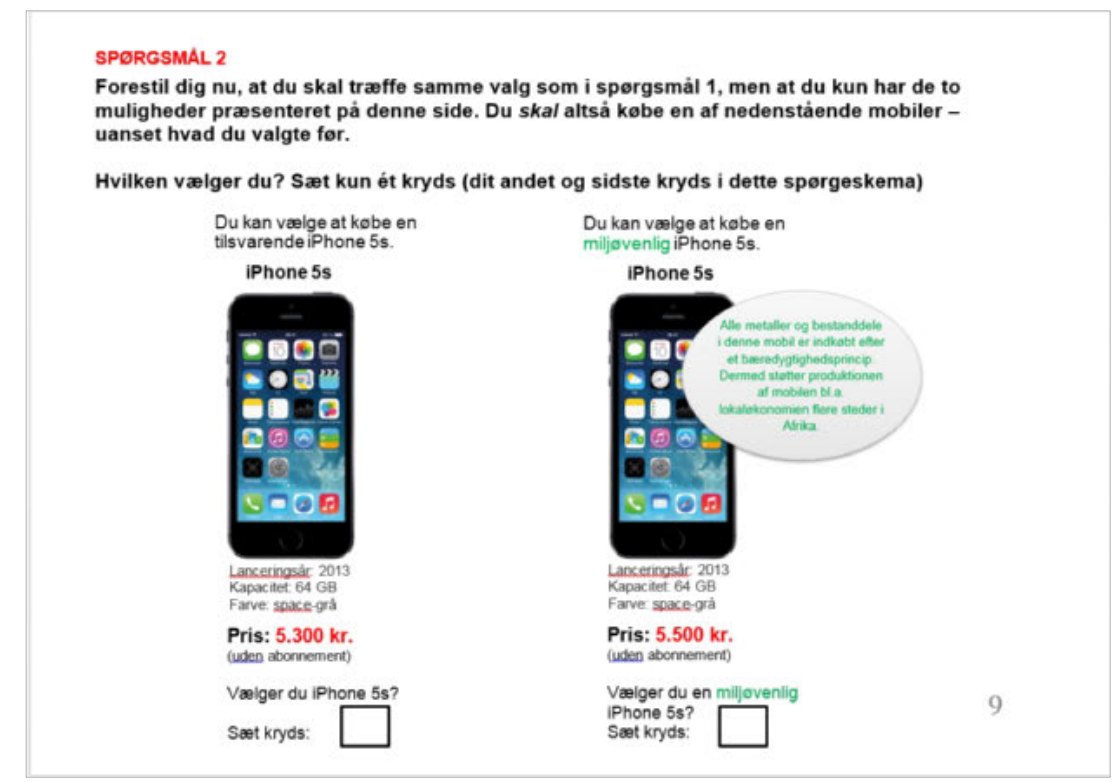


Nordiska ministerrådet

Ved Stranden 18

DK-1061 København K

www.norden.org

\section{Nudging för hållbar konsumtion av elektronikprodukter}

Rapporten fokuserar på möjligheten att använda s.k. nudging för att öka hållbar konsumtion av elektronik: att utan tvång "puffa" konsumenter mot mer hållbara konsumtionsval. Det är många olika faktorer som spelar in när människor bestämmer sig för att agera eller inte agera hållbart i olika situationer. I rapporten kartläggs bl.a. med hjälp av en pilotstudie de viktigaste faktorerna som spelar in vid beslut om konsumtion av elektronik, och hur nudging kan användas för att öka hållbar konsumtion av elektronik. Projektet genomfördes i 2015 av en projektgrupp bestående av konsulter från Copenhagen Economics i Sverige och Danmark och i samarbete med Pelle Guldborg Hansen vid Roskilde Universitet. Projektledare var Amanda Stefansdotter. Nordiska Ministerådets arbetsgrupp för hållbar konsumtio $n$ och produktion (HKP) finansierade och styrde projektet i samarbete med avfallsgruppen NAG. 